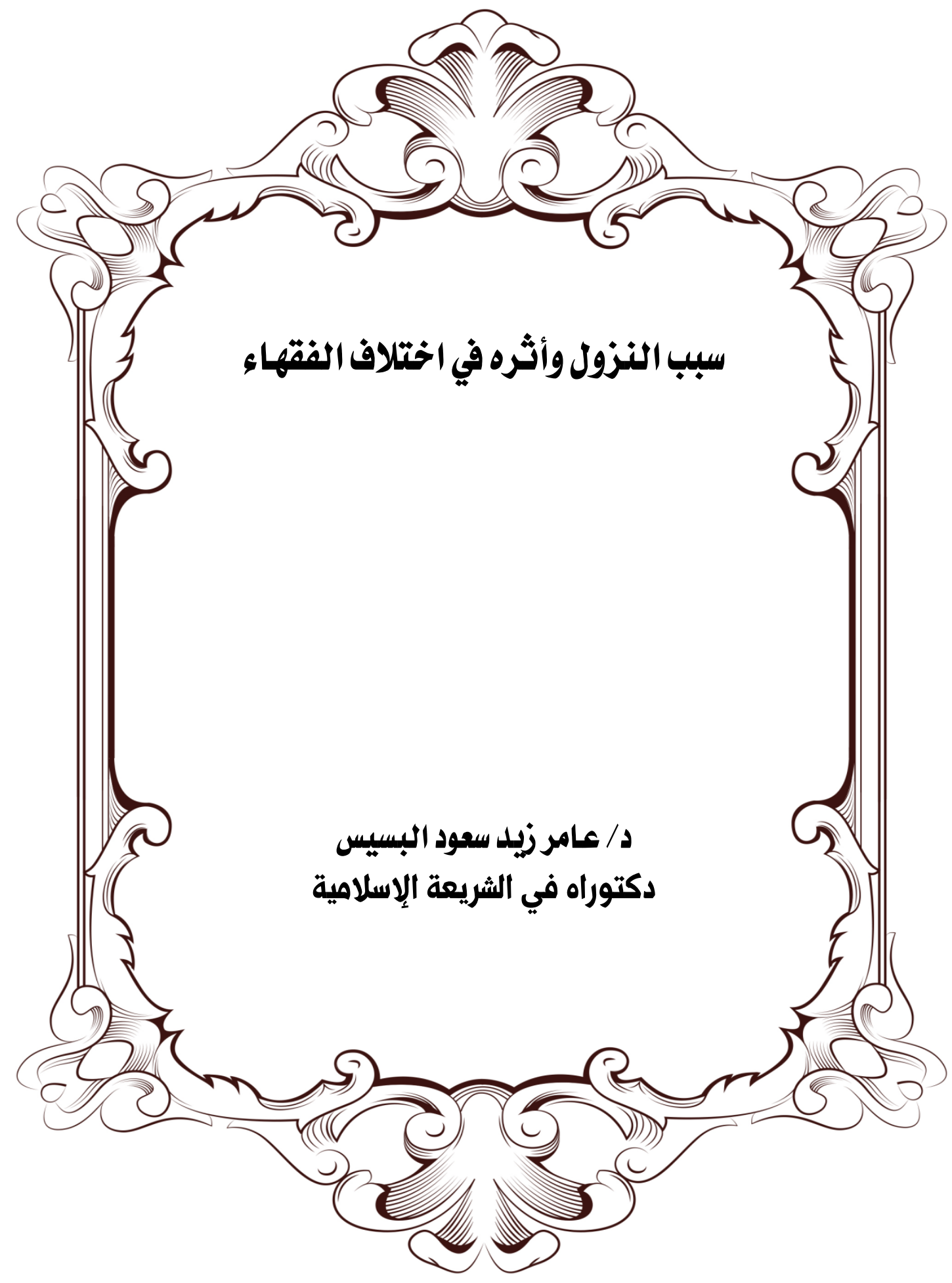


مجلة كلية الدراسات الإسلامية والعربية للبنات بدمنهور العدد الخامس الجزء الرابع عشر •r.rم

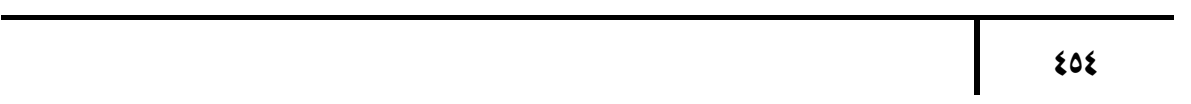




\title{
سبب النزول وأثره في اختلاف الفقهاء
}

\author{
عامر زيل سعود البسيس \\ دكتور اه في الشريعة الإسلامية \\ amer zed@gmail.com : البريد الإكتروني
}

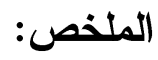

هناك اختلاف في فروع الثريعة فرضته الضرورة تحقيقا لمصالح العبــاد وتيسير ا لهم ورحمة بهم و هذا الاختلاف يقرر الثرع ع ويؤيده العقـلـل ، قـــال

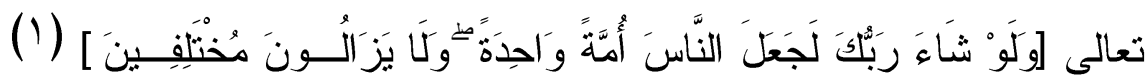
وفال رسول اله

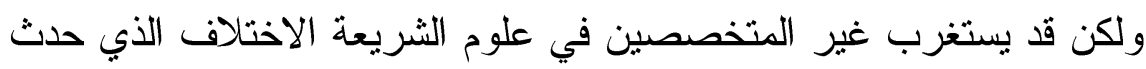
بين العلماء وخاصة مذاهب أهل السنة و الجماعة لاعتقادهم أن القرآن الكريم

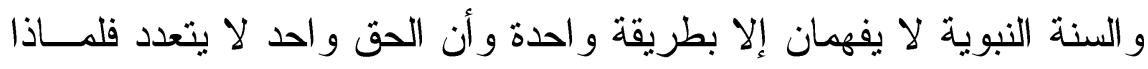

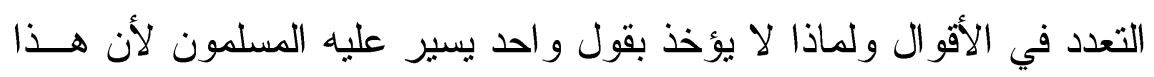

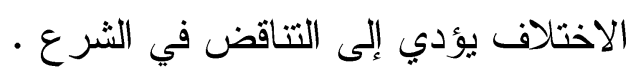
الكلمات المفتاحية: " أسباب النزول - اختلاف الفقهاء - الاختلاف في الحكم

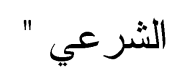


مجلة كلية الدراسات الإسلامية والعربية للبنات بدمنهور العدد الخامس الجزء الرابع عشر •r.rم

\section{The cause of descent and its effect on the different} jurists

\section{Amer Zaid Saud Al-Basis}

\section{PhD in Islamic law}

\section{Email: amer zed@gmail.com}

\section{Abstract:}

There is a difference in the branches of the Sharia imposed by necessity to achieve the interests of the servants and to facilitate them and have mercy on them, and this difference determines the Sharia and is supported by the mind.

However, non-specialists in Sharia sciences may be surprised by the difference that occurred between scholars, especially the doctrines of the Sunnis and the community, because they believe that the Noble Qur'an and the Sunnah of the Prophet are only understood in one way and that the truth is one and the same. To the contradiction in the Sharia.

Key words: "The Reasons For Revelation - The Difference Of Jurists - The Difference In The Legal Ruling". 


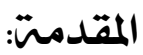

مما لا شك فيه أن القرآن الكريم ذم الخلاف المبني على الهوى و إتباع

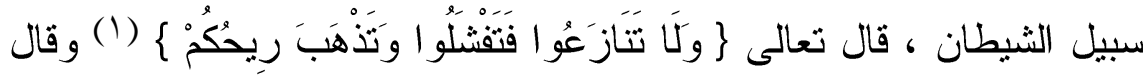

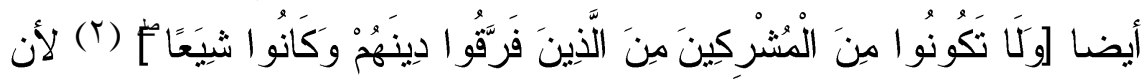

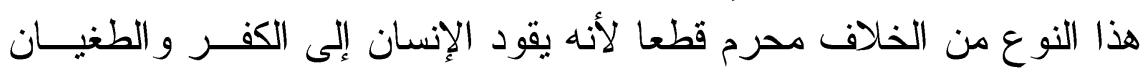

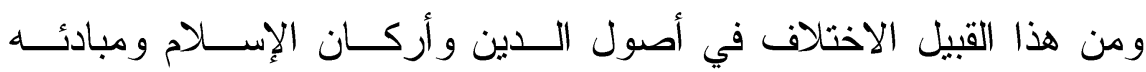
الأساسية.

نعم هنالك اختلاف في فروع الثريعة فرضــته الضـــرورة تحقيقـا

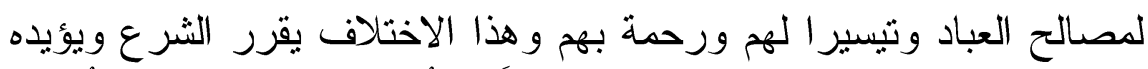

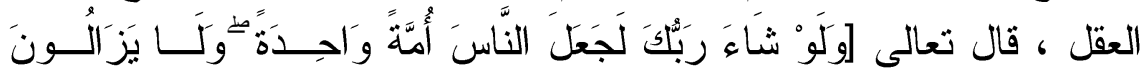

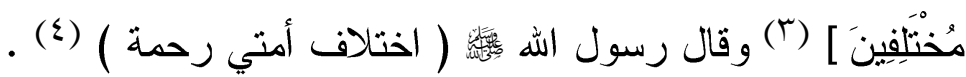
ولكن قد يستغرب غير المتخصصين في علوم الثريعة الاختلاف الذي رلهي

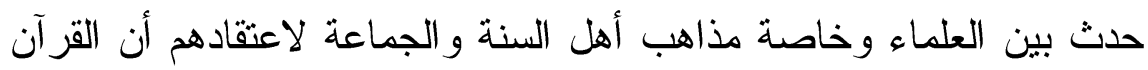

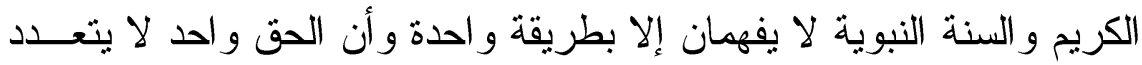

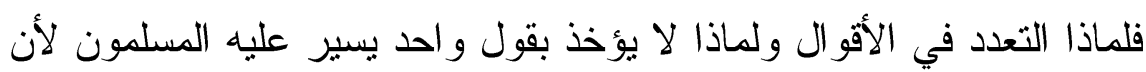

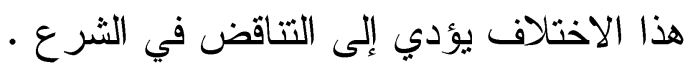

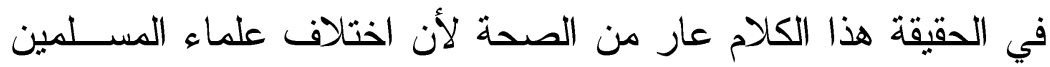

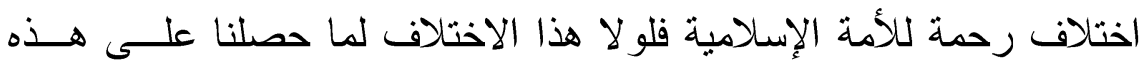

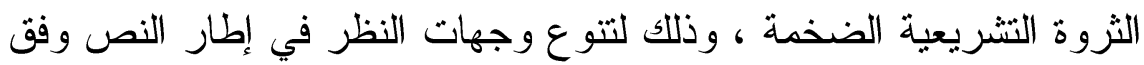

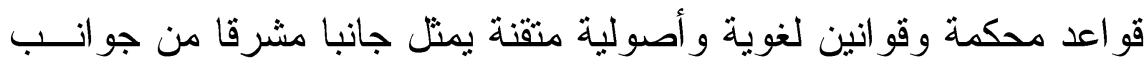

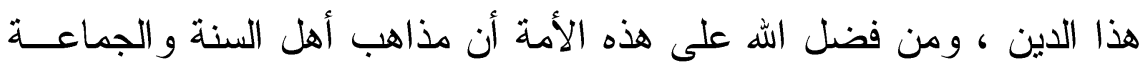
كما قلنا لم يقع بينها اختلاف في العقائد ولا في أصول الدين الدين ولم نسمع على اهلى

$$
\begin{aligned}
& \text { (1) الأنفال (T؟) . (Y) }
\end{aligned}
$$

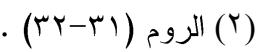

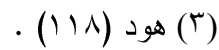

(§) ذكره القرطبي (ع/101) و الخطابي في غريب الحديث ، وقال الثيخ الألباني : لا أصل له ، وقال

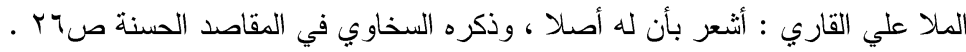


مر العصور أن هذا الاختلاف أوقع نزاعا أو تصادما بين أبناء الأمة مدــا

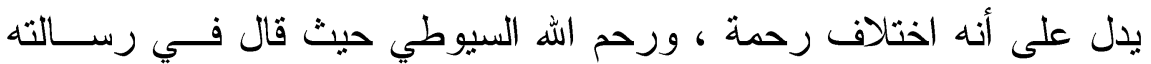

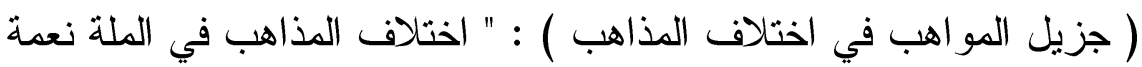
كبيرة وفضيلة عظيمة وله سر لطيف أدركه العالمون وعمى عنه الجاهلون

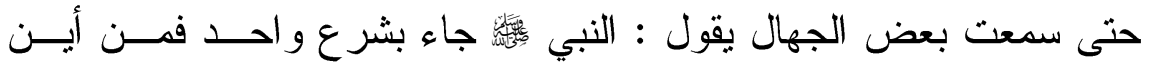

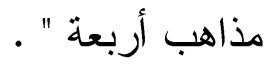

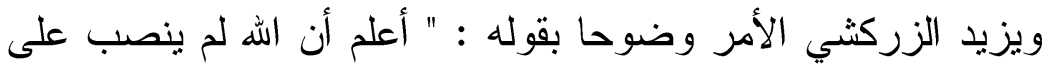

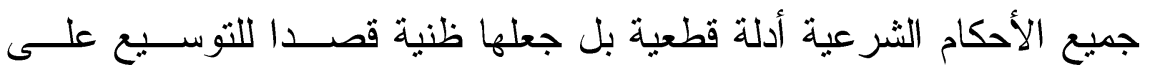

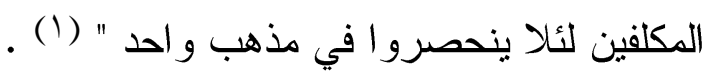

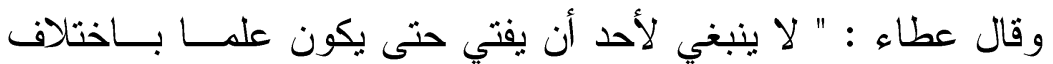

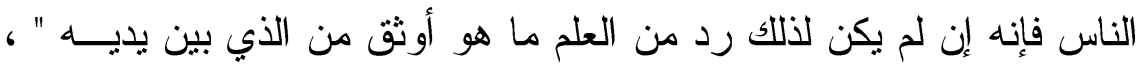

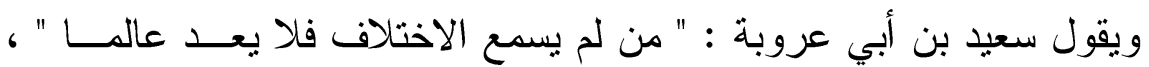

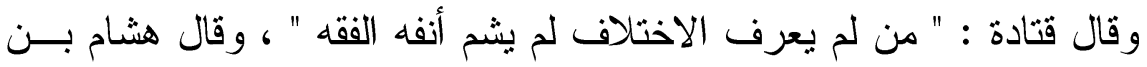
عبد الله الرازي : " من لم يعرف اختلاف الفقهاء فليس بفقيه " (r) .

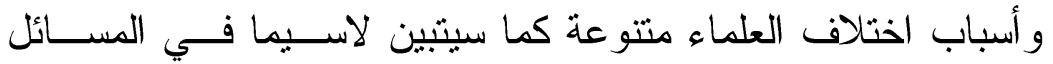

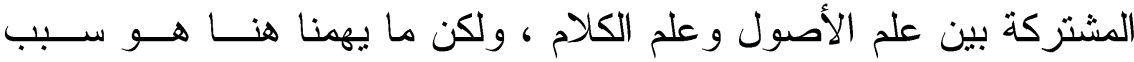

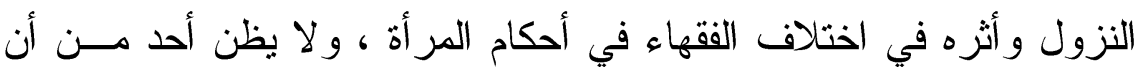

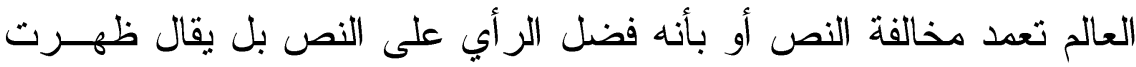

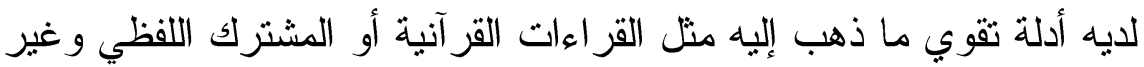
ذلك (r) . (ن) وقد قسمت هذا البحث إلى مقدمة ومبحثين : -المبحث الأول :أسباب اختلاف الفقهاء. -المبحث الثاني : سبب النزول وأثره في اختلاف الفقهاء. 


\section{المبحث الأول \\ أسباب اختخلاف الفقهائ}

قبل أن نتكلم عن أسباب اختلاف الفقهاء فإنه يجدر بنا أن نتعرف على إعلى معنى أسباب الاختلاف فنقول وباله التوفيق :

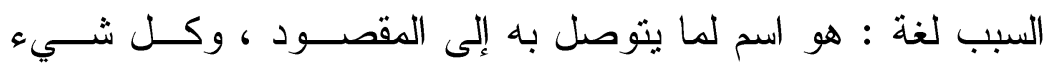
يتوصل به إلى شيء غيره فهو سبب (1) .

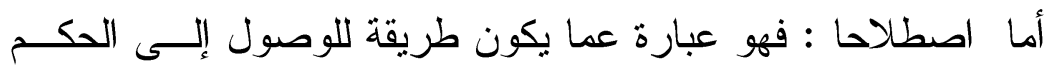

$$
\text { غير مؤثر فيه (r) }
$$

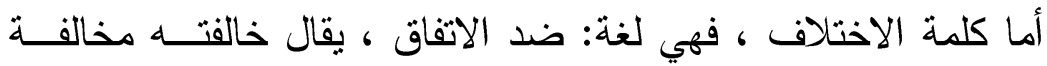
وخلافا ، ويقال تخالف القوم اختلفو ا إذا ذهب كل واحد إلى خلاف ما ذهب ، الدب ، إليه الآخر (r) ، أما الاختلاف اصطلاحا : فيستعمل الاختلاف في قول مبني على دليل (§) ، وقد استخدم الفقهاء الكلمنين - الاختلاف و الخلاف - بمعنى

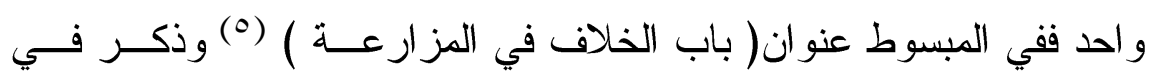
موضع آخر باب ( الاختلاف في البيوع )(†' . .

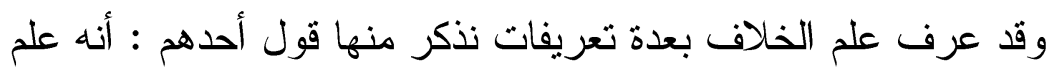
يتوصل به إلى حفظ الأحكام المستتبطة المختلف فيها بين الأئمة أو هدمها لا

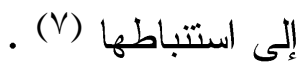

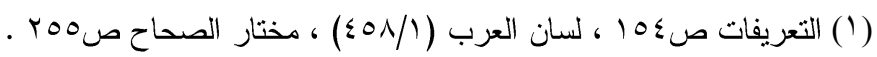

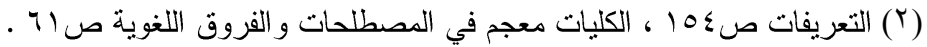

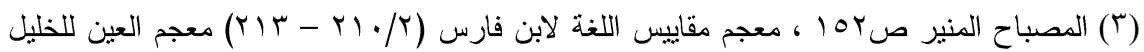

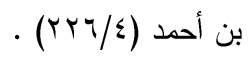

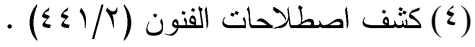

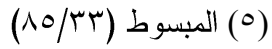

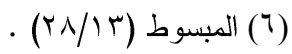

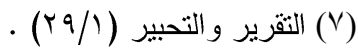


وعرف آخر بأنه : علم يعرف به كيفية إيراد الحجج الثرعية ودفع

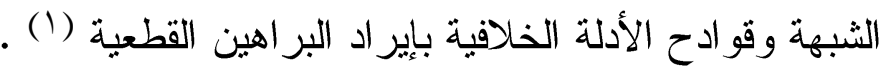

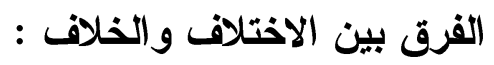
( الاختلاف : هو أن يكون الطريق مختلفا والمقصد واحدا ، أما الخلاف :

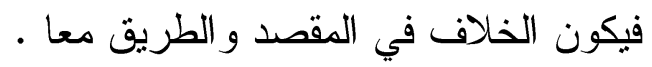

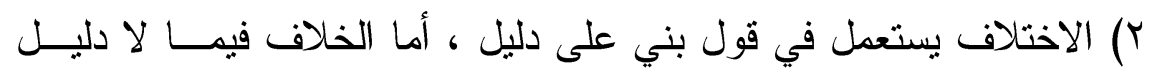
عليه.

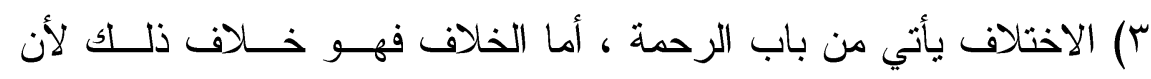

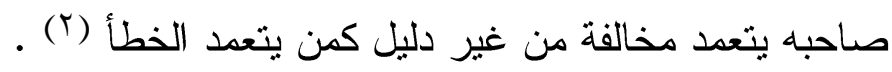
أنواع الاختلاف عند العلماء : قسم الفقهاء الاختلاف إلى محمود وهو المشروع ، ومـــموم وهـــ

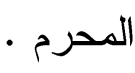

أما المحمود : شرعا فهو ما وقع بين المجتهدين من الفقهاء في مسائل الفروع الفقهية التي أذن الثارع بالاجتهاد فيها (r) ، ومن هذا المنطلق قال رسول الله

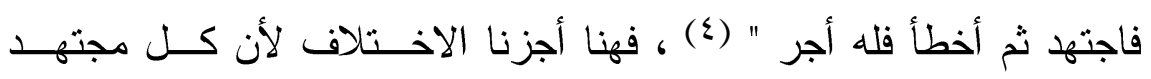

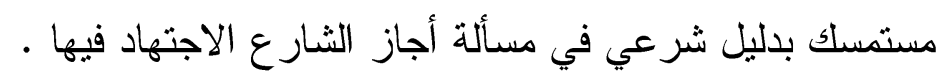

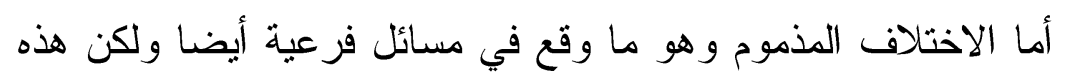

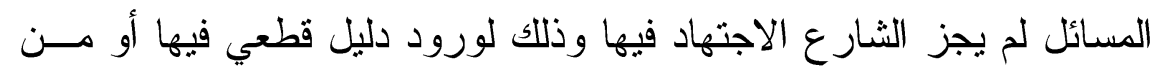

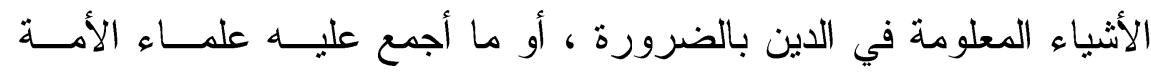

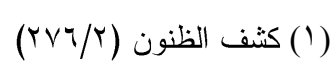

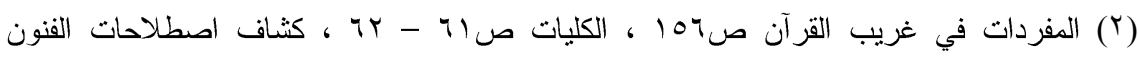
.

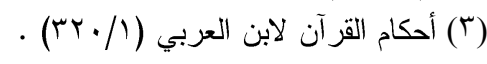
(§) رواه البخاري كتاب الاعتصام بالكتاب والسنة باب أجر الحاكم إذا اجتهد فأصاب أو أخطأ . 
كمسائل المير اث و الكفار ات و الحدود وغيرها فهذه مسائل لا يجوز الاجتهاد

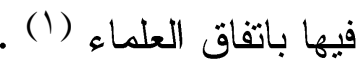

\section{نشأة الاختلاف الفقهي وتطوره :}

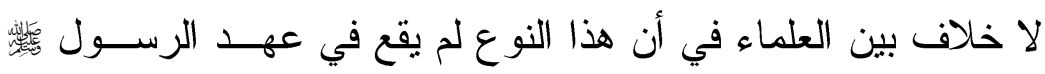

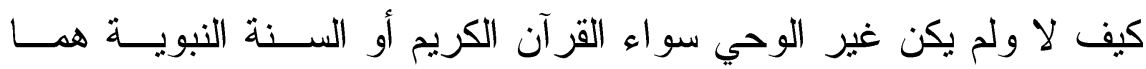

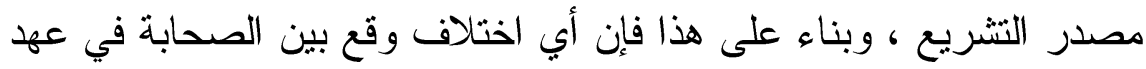
رسول الله

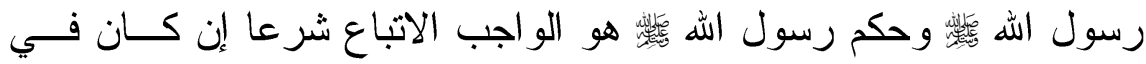

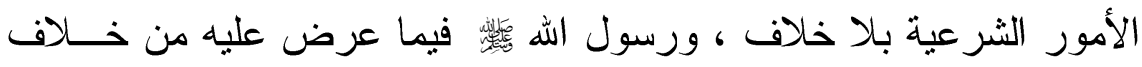

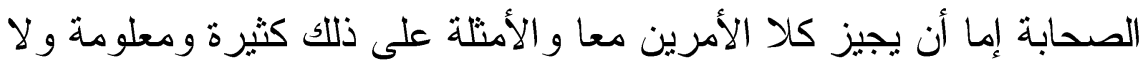
داعي لتكر ارها ونكتفي بالمثال المشهور حيث قال : لا يصلين أحدكم العصر

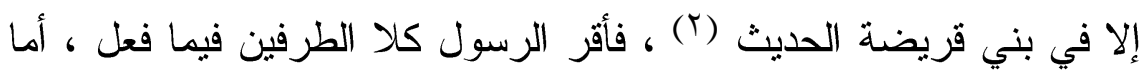

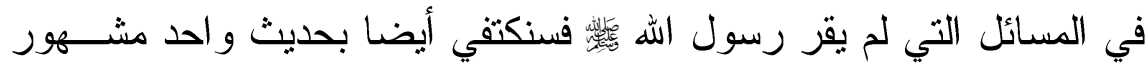

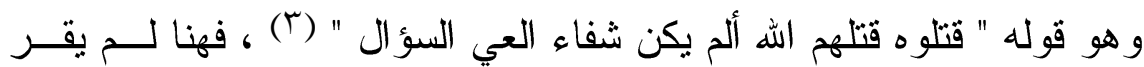
رسول الله اجتهاد من قال بوجوب غسل من أصابه الجرح عنـــما أصــبح جنبا.

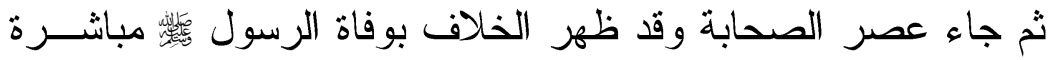
ولعل أشهر مسائل الخلاف هي مسألة تولي الخلافة بعد موت رسول الله وما حدث في اجتماع سقيفة بني ساعدة ثم الإجماع على تولية أبي بكر الصديق

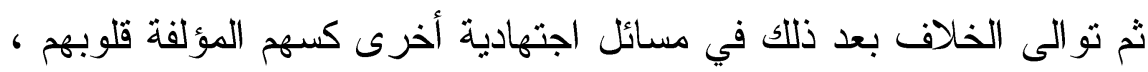

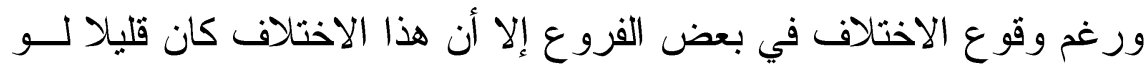


قورن بالعصر الذي بعد الصدابة ، ويرجع الفضل في عدم اتساع الخــلاف

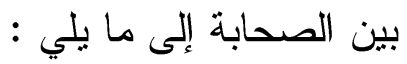

(1) تقرير مبدأ الثورى بين الصحابة الأمر الذي كان يؤدي في مسائل كثيرة

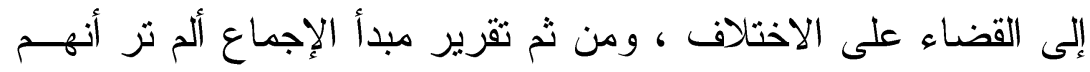

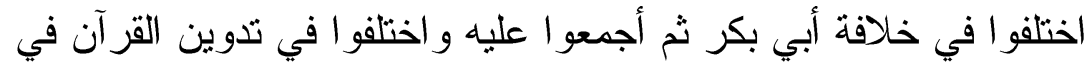

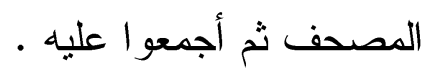

r) قلة النوازل بالنسبة لما وجد منها في العصور الثالية . لإنه

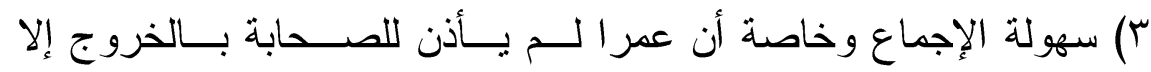
لض لضرورة. ع) قلة عدد المفتين . 0) هؤلاء المفتون - رغم قلتهم - كانوا يتورعون عن الفتــوى ويحيلــون بعضهم إلى بعض.

بانقضاء عصر الصحابة وخاصة بعدما أذن عثمان لهم بالتفرق في الأمصار ، ونشر علم رسول الله

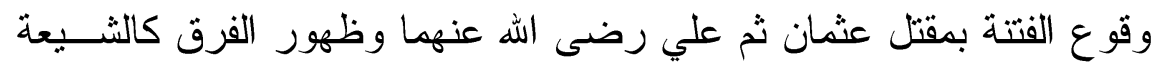

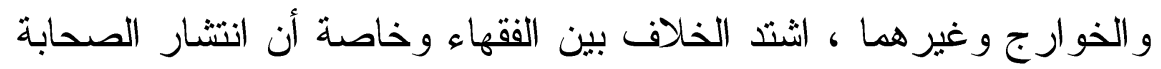

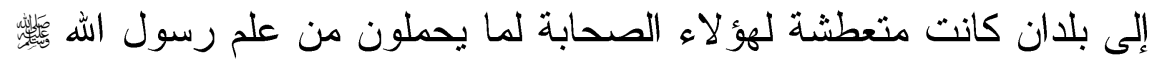

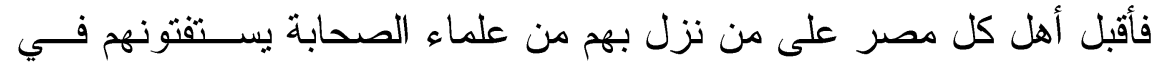

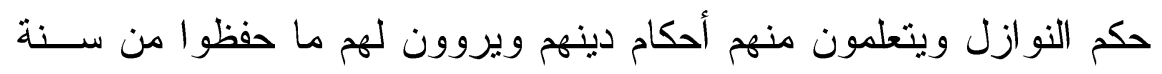

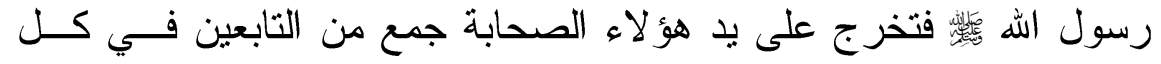

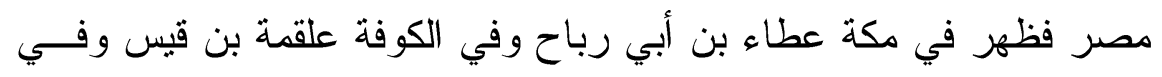
البصرة ابن سيرين وفي الثام عمر بن عبد العزيز وفي مصر بزئ بليد بن أبي

حبيب وفي اليمن عبد الرزاق بن همام الصنعاني (1) . 
ثم ازداد ظهور الفقهاء حتى ظهرت المذاهب الأربعة وهي المذاهب

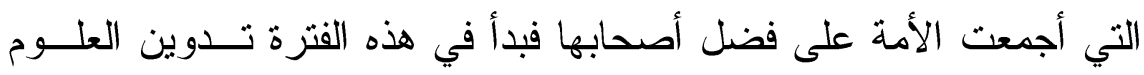

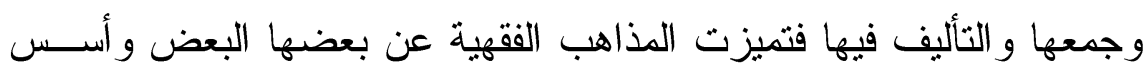

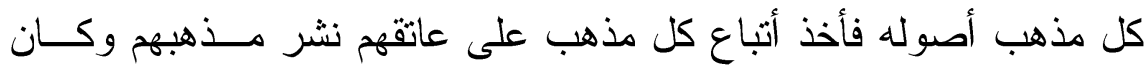

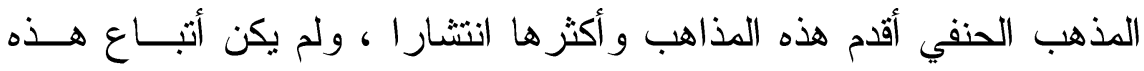
المذاهب في بادئ الأمر عن تقليد أو تعصب أعمى حتى نهاية القرن الثالث

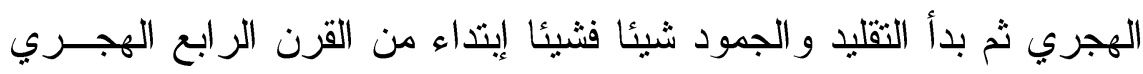

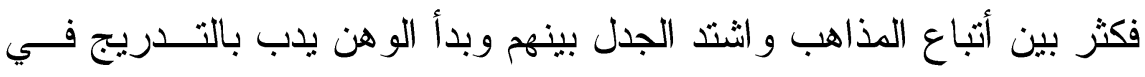

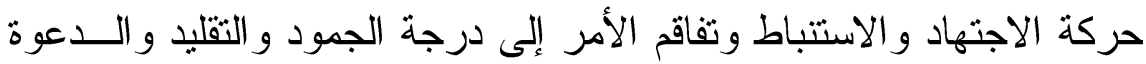
إلى سد باب الاجتهاد (1) ، ورغم تحفظنا على تسمية هذه الفتــرة باتهــام علمائها بالجمود و التقليد ، وقد ناقشنا هذا الأمر بالتقصيل في كتابنا تـاريخ التشريع الإسلامي(r) إلا أن الضرورة تقتضي إجمال الأسباب التي دفعتـــا إلى عدم تسمية هذه الفترة بفترة الجمود و التقليد لما يلي : () وصف الفترة من القرن الر ابع الهجري حتى القرن الثالث عثر الهجري لئي

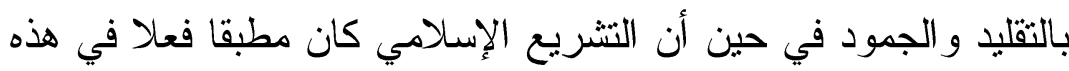

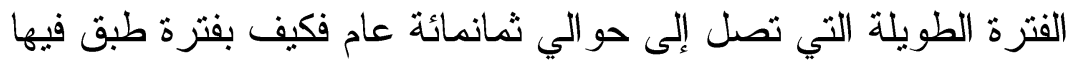

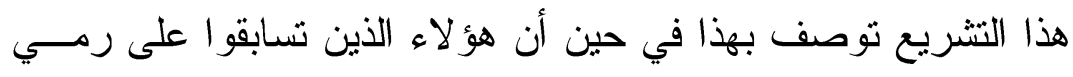

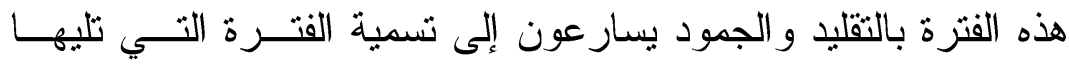

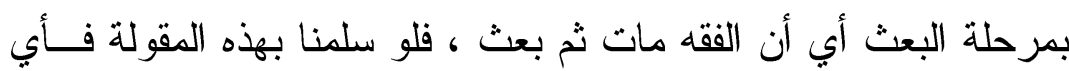

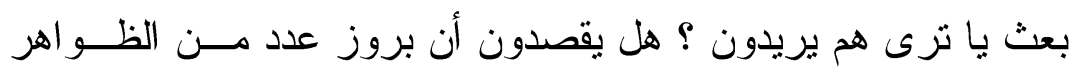

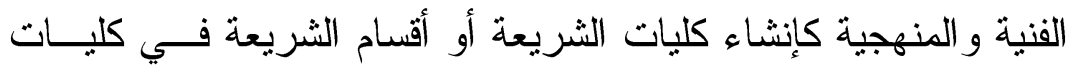

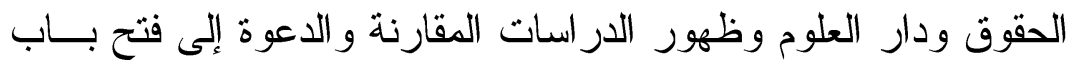

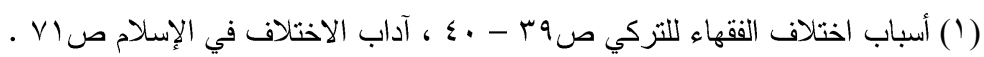

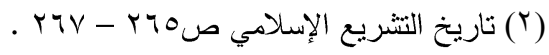


الاجتهاد و الاتجاه إلى التقريب بين المذاهب وعقد المؤتمر ات الدوليـــة لار اسة الفقه الإسلامي كان بعثا (1) ، كل هذه الأمور مجتمعة لا تحقق

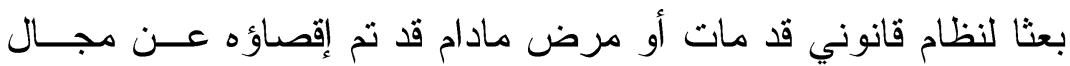

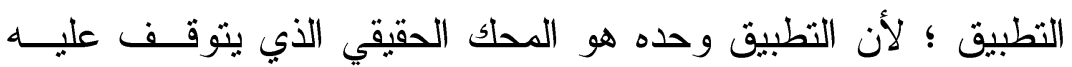

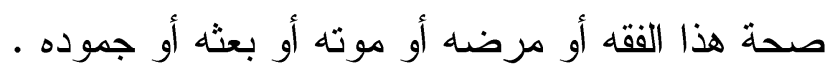
r) وصف هذه الفترة بالجمود أسقاط للكثير من جهود علماء هذه الفترة من هن هنه تعليل الأحكام وتعقيد القواعد الأصولية والترجيح بين الآراء وغير هذاء هذهاء كثير

r) ظهور مجموعة من العلماء المجددين من أمثال الثوكاني وابــن ثيميـــة

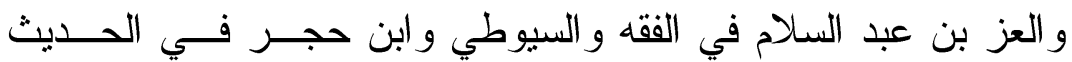
و غير هم كثير ، وكثرة مؤلفات هذا العصر خير شاهد على الدور الذي ولي قام به علماء هذا العصر ولعل الجهود التشريعية التي قامت بها الدولة هولة العثمانية خير شاهد على ما قلنا .

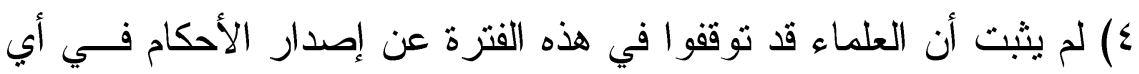
مسألة نزلت بالمسلمين أو أن أحد هؤلاء العلماء تتصل عن مســؤوليته

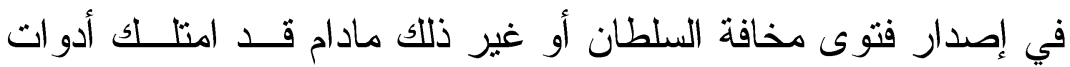

\section{الاجتهاد (r) .}

من أجل هذه الأسباب لا يمكننا القول بأن هذه الفترة من تاريخ الفقـــه

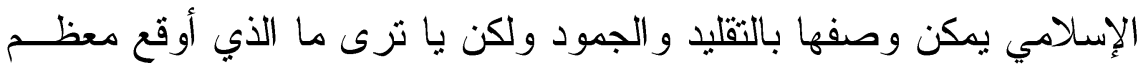

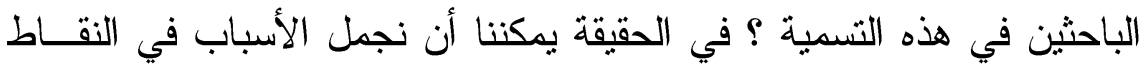


1) مما لاشكك فيه أن مقولة الكرخي وهي ( إن كل آية أو حسديث جـاءت

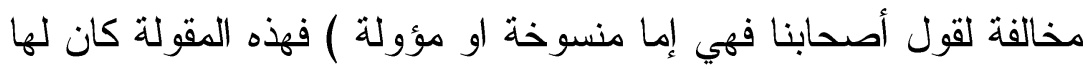

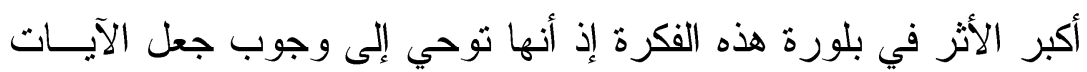

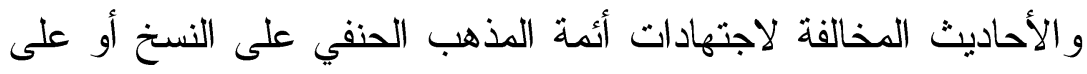

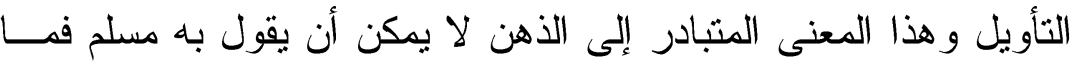
بالنا وقد نسبت إلى العالم الجليل .

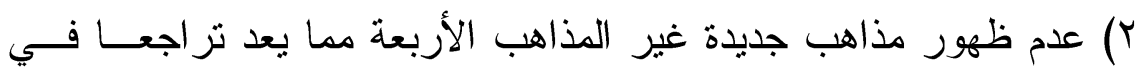

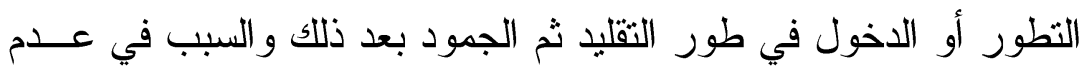

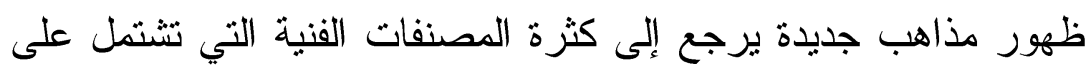

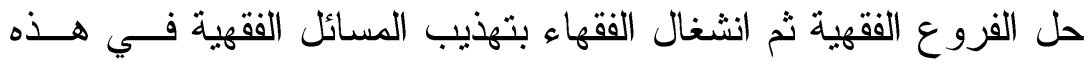

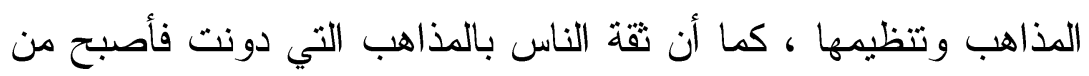

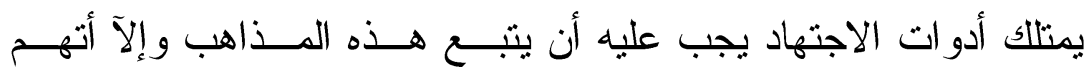

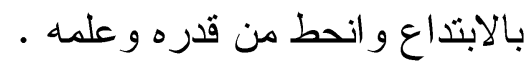

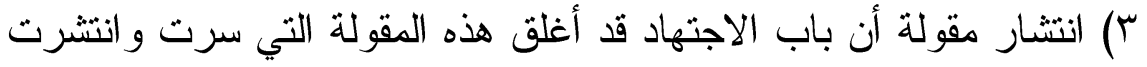

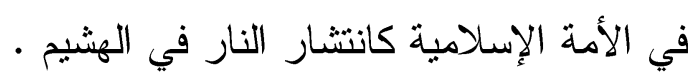

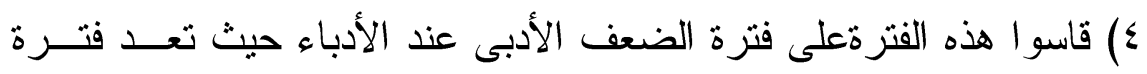

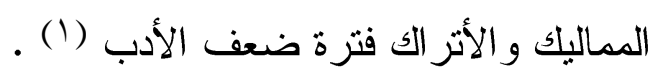

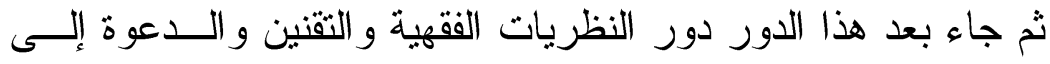

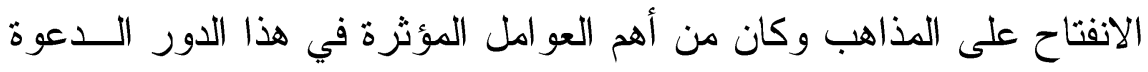

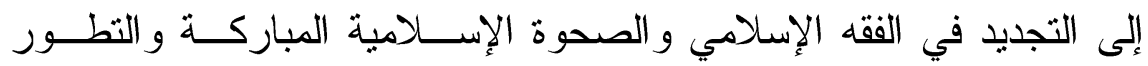

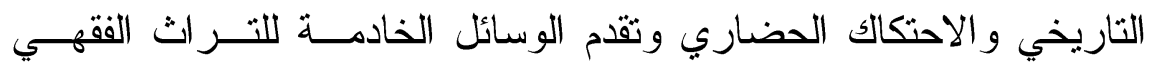


مجلة كلية الدراسات الإسلامية والعربية للبنات بدمنهور العدد الخامس الجزء الرابع عشر •r.rم

وظهور الموسوعات و المجامع الفقهية وعقد المؤتمر ات الفقهية و الدعوة إلى

(1) التقنين 


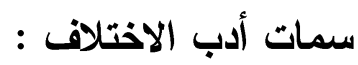

( ) تحاشي الاختلاف و الحرص على عدم وقو عله .

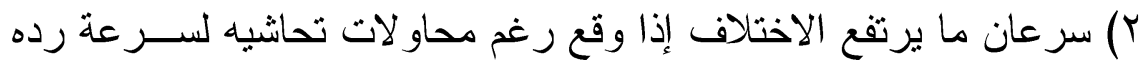

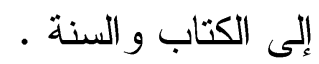

r) إن كل مجتهد يشعر أن ما وصل إليه صو اب يحتمل الخطأ وما وصــل

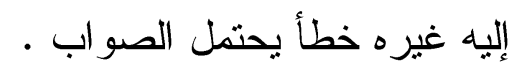

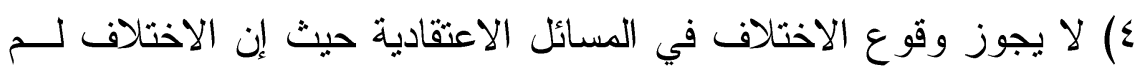

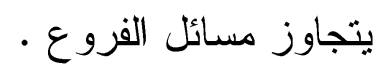

0) تجنب الهوى وذلك من شأنه أن يجعل الحقيقة وحدها هــدف المختلفــين

لا يهم أي منهما أن تظهر الحقيقة على لسانه أم لسان غيره (1) .

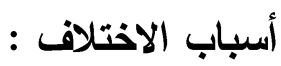

كما سيتبين لنا في الجانب التطبيقي أن أسباب الاختلاف متتوعة فمنها ما يرجع إلى القرآن الكريم ومنها ما يرجع إلى السنة النبوية أو إلى غيرها

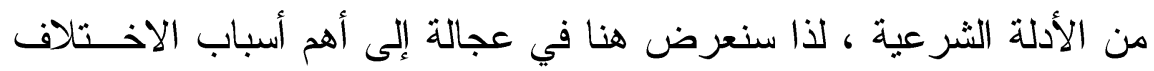
بين الفقهاء : من الأه أولا : اختلافهم في فهم القرآن آلكريم : الكراء

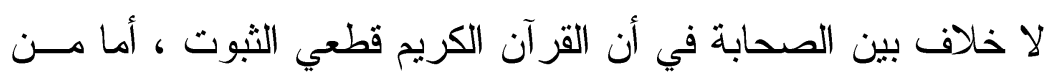

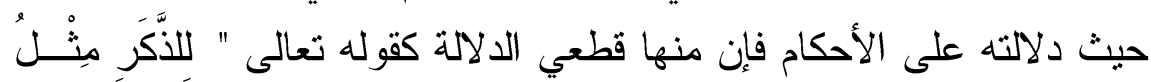

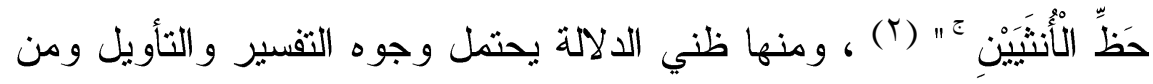
أمثلة ذلك : 


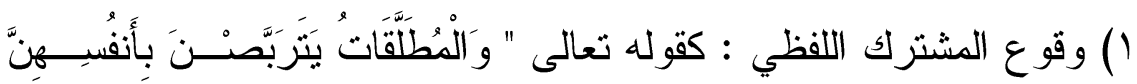

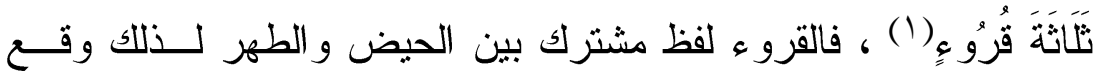

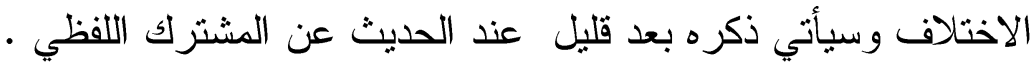

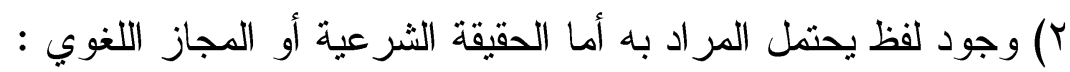

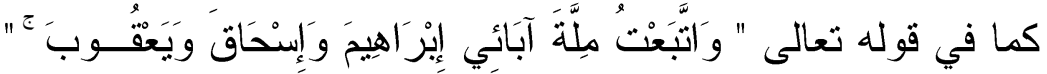

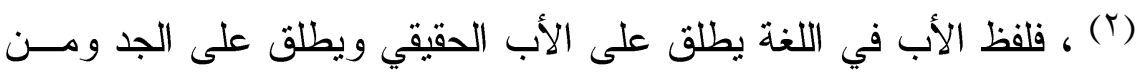

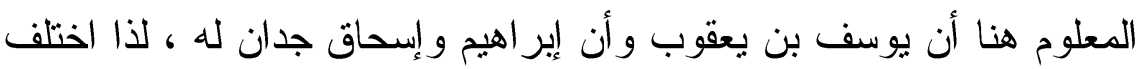

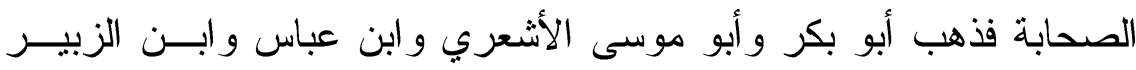

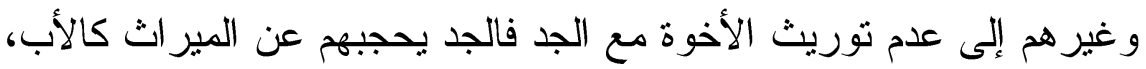

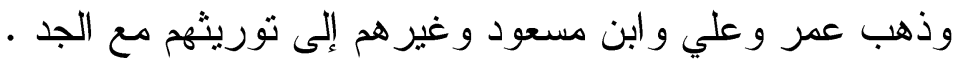

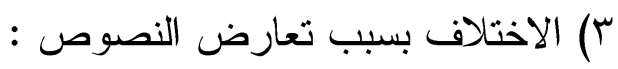

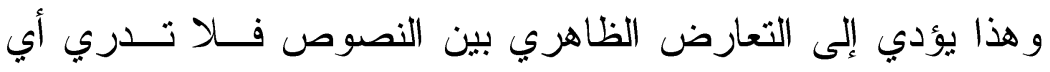

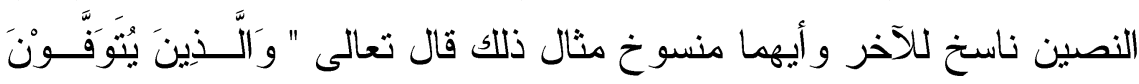

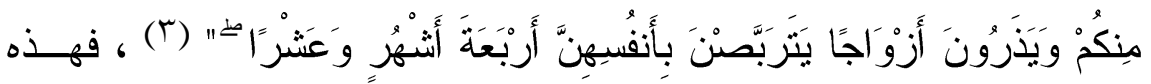

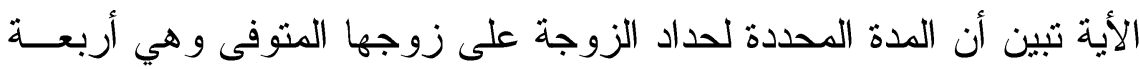

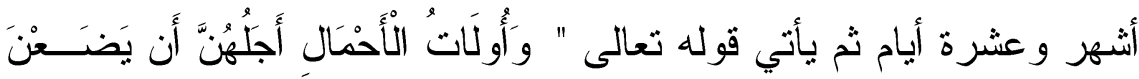

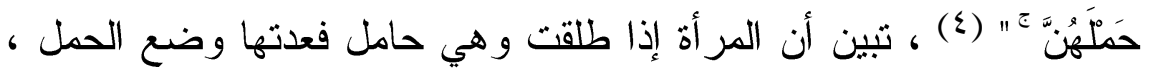

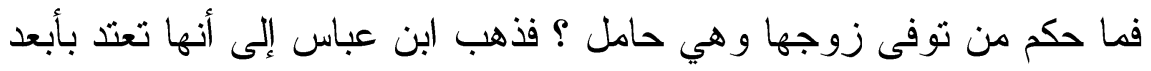

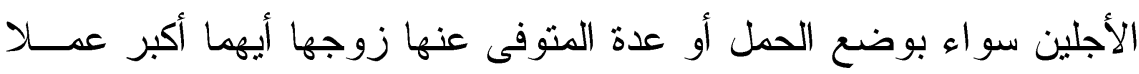

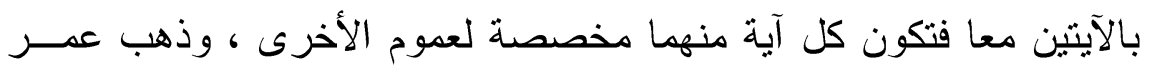


و ابن مسعود ومن و افقهم إلى أنها تعتد بوضع الحمل وأن آية الطلاق ناسخة

لآية البقرة (1)

ع) الاختلاف بسبب القراءات القرة آنية :

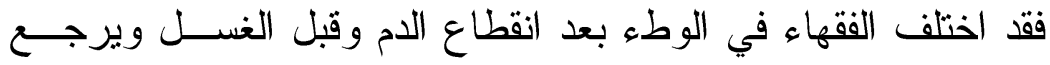

سبب الخلاف إلى اختلافهم في قر اءة قوله نعالى ( يطهرن ) (r) فقد قرئت بالتخفيف وتعني انقطاع الدم وبالتشديد وتعنني الاغتسال وسيأتي تفصيل هذه القر اعة بشيء من التفصيل في الدر اسة التطبيقية . 0) الاختلاف بسبب نزول الآية :

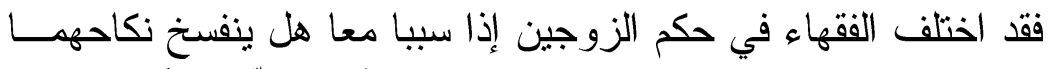

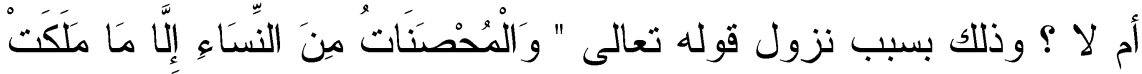
أَيْمَانكُمْ هِّ" (T) إذ العبرة هنا بعموم اللفظ أم بخصوص السبب وسيأتي تفصيل

هذه الآية في الدر اسة التطبيقية .

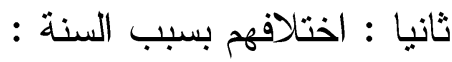

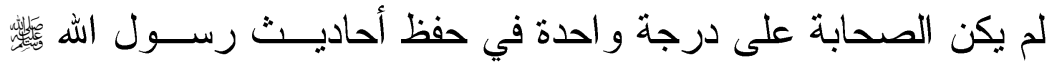
و الإلمام بها ويرجع ذلك إلى الأسباب التالية :

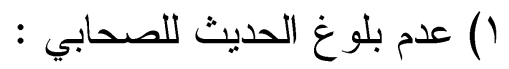

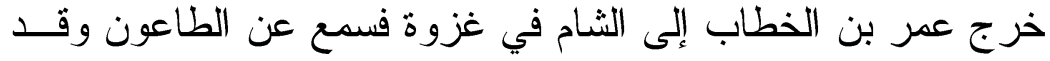

وقع في الثام فر أى عدم الآخول و الرجوع ، فقال له أبو عبيدة بن الجر الح :

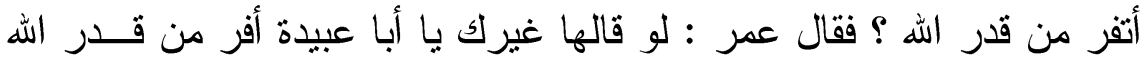

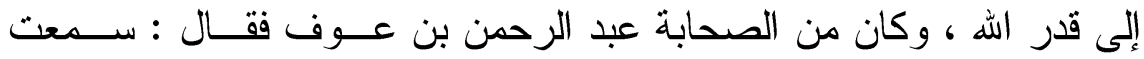
رسول الله

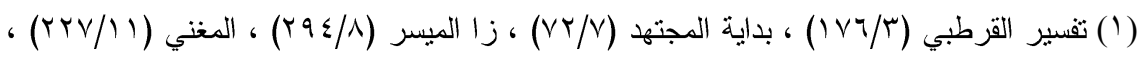

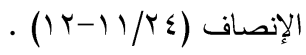

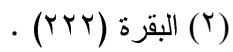

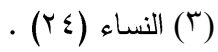


و إذا وقع بأرض و أنتم فيه فلا تخرجو ا فرار ا منه ( (1) فقرح عمر بن الخطاب

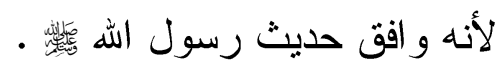

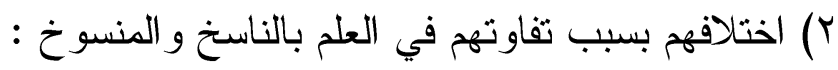

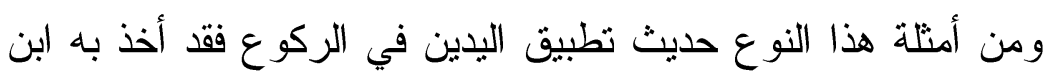
مسعود ولم يطلع على أنه منسوخ ، و أطلع سعد بن أبي وقاص على على نلى ناسخه فرو اه. كما أفتى أبو هريرة بأن من أصبح جنبا فليفطر ، وهذا حكــــــــان

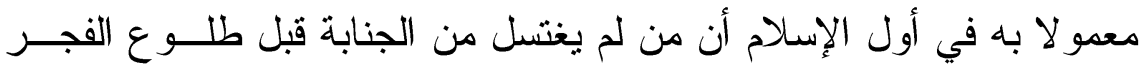

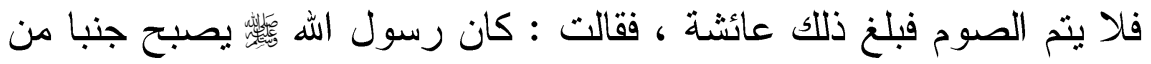
أهله ثم يغتسل ويتم صومه (r) ، فلما بلغ أبو هريزة هذا الحديث رجع عن ، فتو اه. r) اختلافهم بسبب فهم حديث رسول اله : كما في حديث ( لا يصلين أحدكم

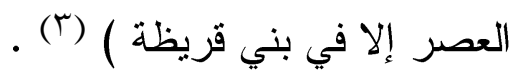

؛) اختلافهم في فعل رسول الله كما في الرمل في الطواف فقد رمل الرسول وكذا الصحابة ، وكــان

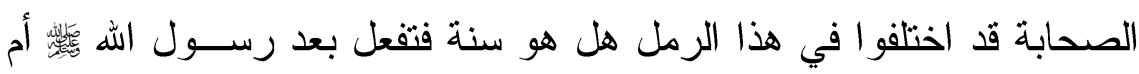

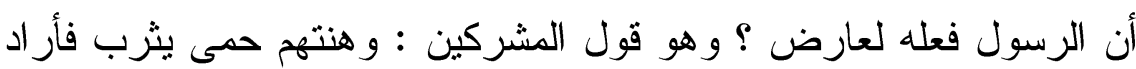

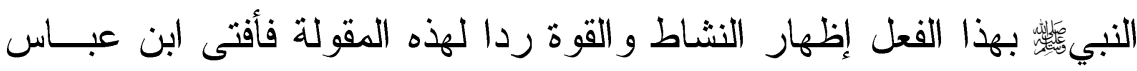

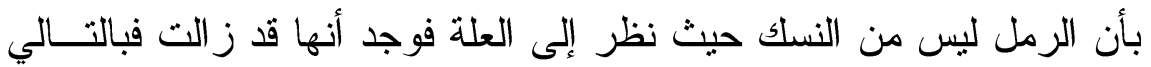

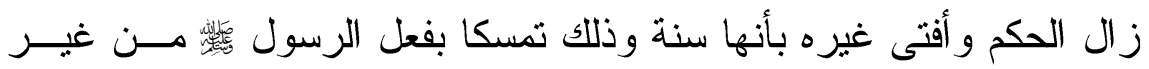
النظر لزو ال المراجع. - مان. 0) رد الحديث لعدم الثقة في سماع الصحابي : لرول 
كرد عمر بن الخطاب و عائشة لحديث فاطمة بنت فــيس فــي نفقــة

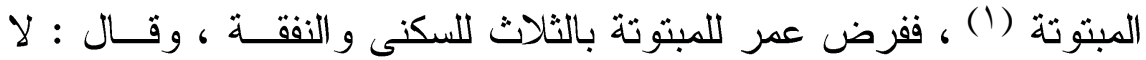

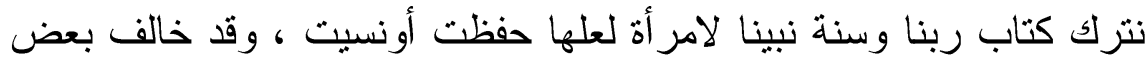

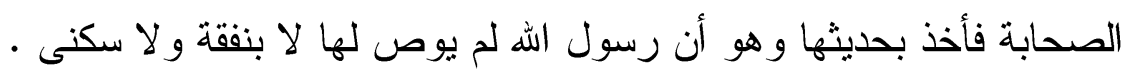
ثالثا : اختلافهم في الر أي : مما لا شك فيه أن العقول تثتفاوت من حيــث قــــوة الإدر الك وملكـــة الاستتباط كما أن الخلاف قد يقع باختلاف الزمان و المكان و هناك أمثلة كثيرة خاصة باختلاف الفقهاء في استعمال الرأي منها :

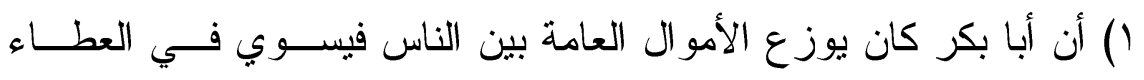

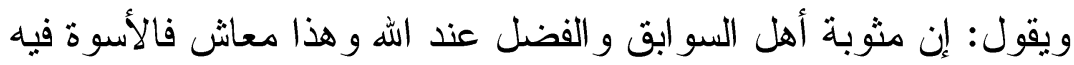

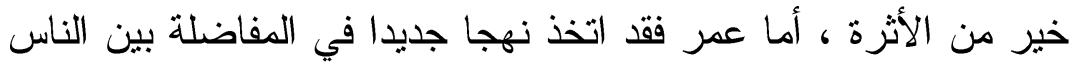

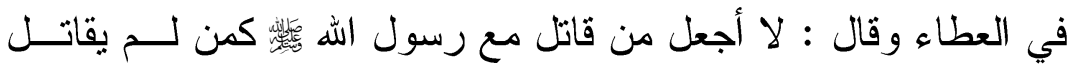

$$
\text { مe (r) }
$$

ويعد الاختلاف بسبب الر أي من أهم أسباب الاختلاف بين الفقهـــاء إذ

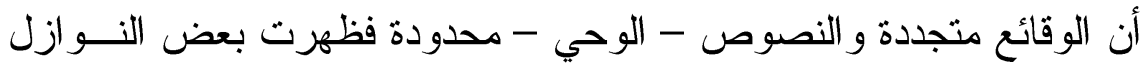

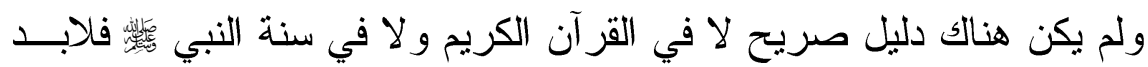
من معرفة حكمها و لا سبيل إلى ذلك إلا بالنظر فيما جاء في الكتاب و السنة

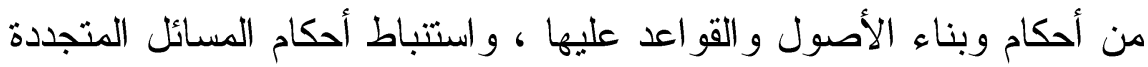
منها كل هذا لا يتم إلا عن طريق الاجتهاد ، وما كان سبيل العلم به الاجتهاد

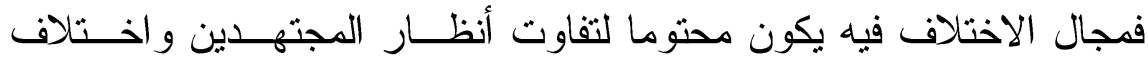
مداركهم وتقدير اتهم ووزنهم للأمور (r) .

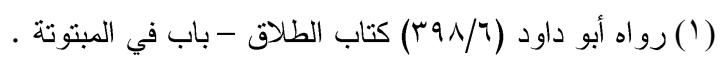

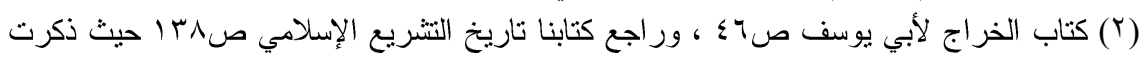


فو ائد معرفة أسباب الاختلاف :

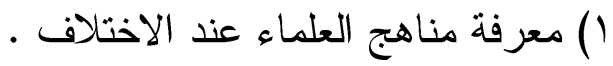

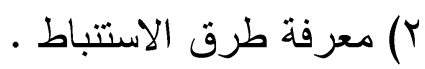

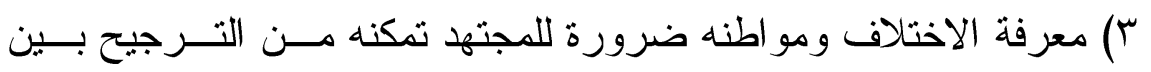

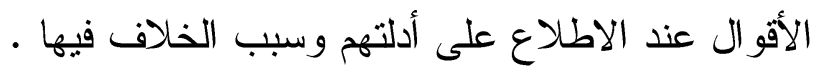

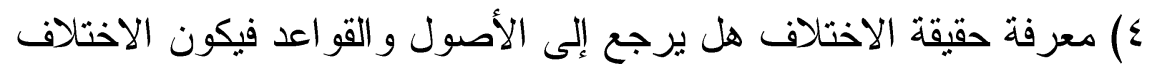

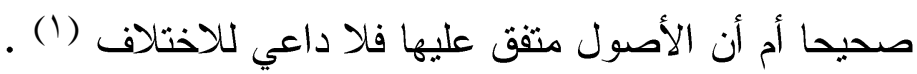
موقف الفقهاء من الاختلاف :

لم تثفق كلمة الفقهاء في جواز الاختلاف في فروع الثريعة بل اختلفو ا إلى فريقين أحدهما مؤيد و الآخر معارض و وإليك بيان رأي كل فريق : الفريق الأول: وهم القائلون بالجواز :

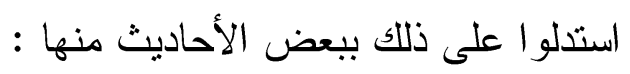

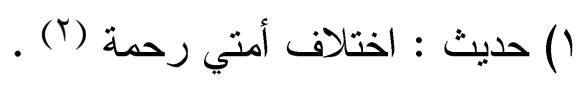

و الاستدلال في الحديث و اضح على أن الاختلاف في الآر اء ما لم يكن

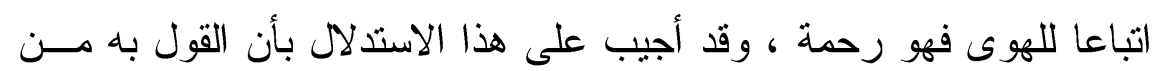

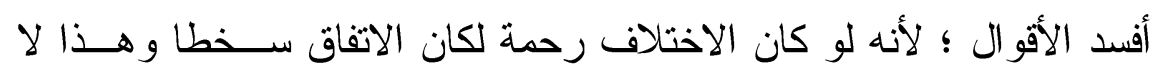
يقول به عاقل (r) ، أضف إلى ذلك اتفاق أهل الحديث على ضعفه .

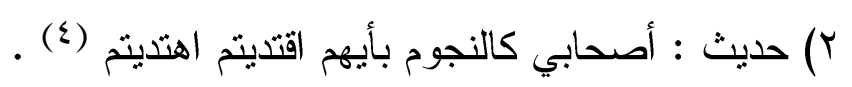

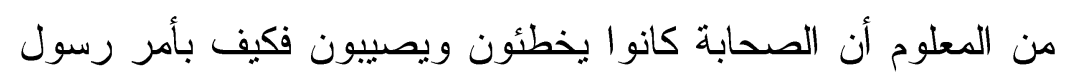
الله

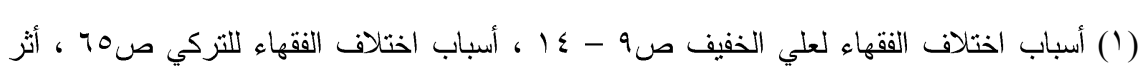

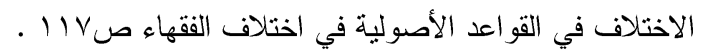

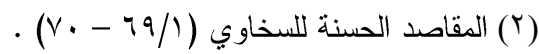

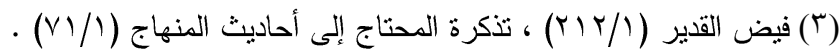

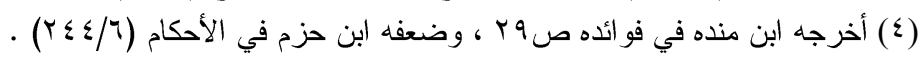


كما ورد في الحديث وفي ظل انقطاع الوحي بعد موت الرسول حتى قبـام

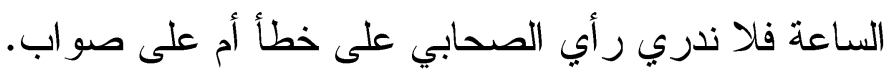

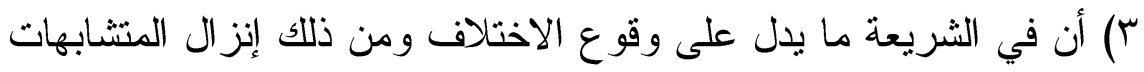
و الأمور الاجتهادية فهي مجال لتباين الأنظار واختلاف المدارك و الآراء.

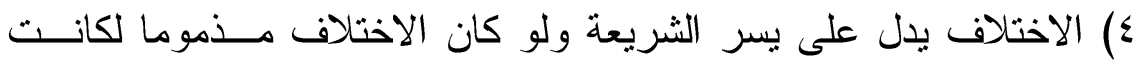
النصوص غير قابلة للاختلاف ، ولما جاءت بعض النصـــوص مجملــة

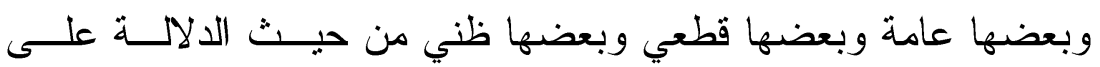

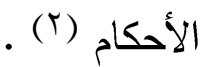
وأجيب بأن القرآن ذم الخلاف في مواطن كثيرة .

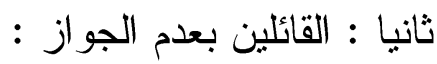
استذلو ا على ذلك أيضا بعدة أدلة منها :

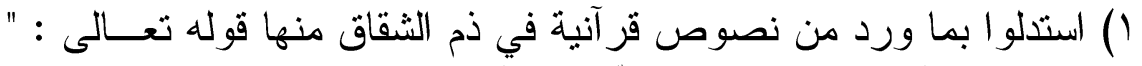

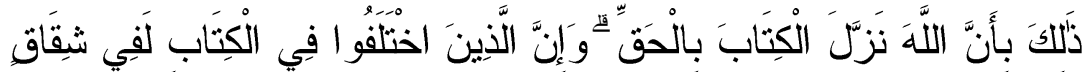

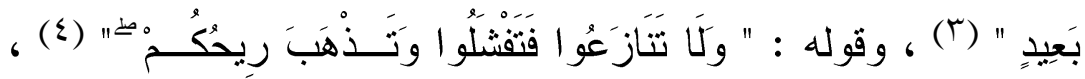

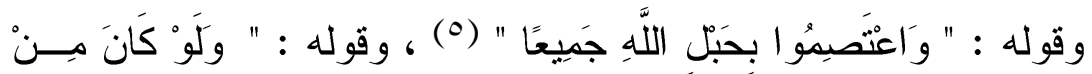

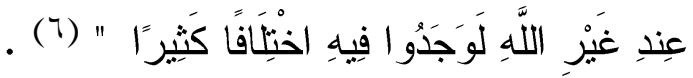

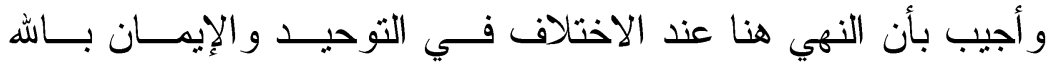
ورسوله و التخاذل عن نصرة الدين و الاختلاف في القطعيات .

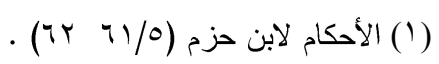

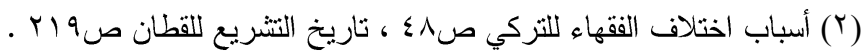




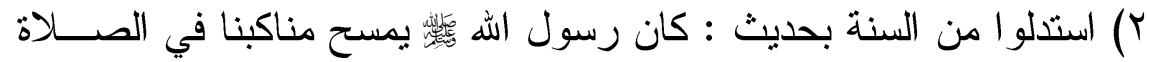

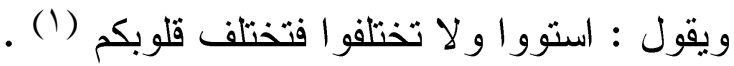

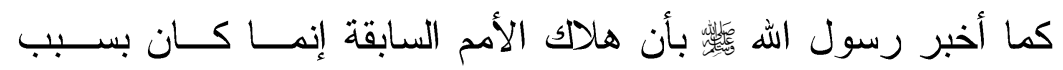
الاختلاف (r) ، فقي الحديث ( إنما هلك من كان قبلكم بسؤ الهم واخـتلافهم

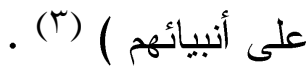

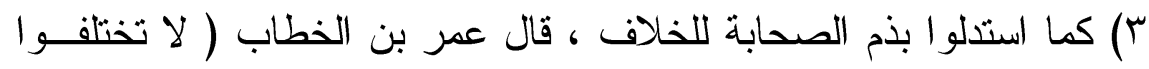

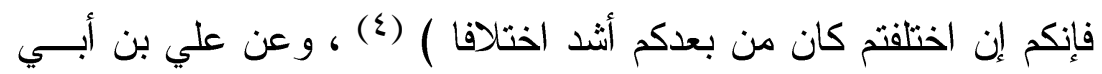

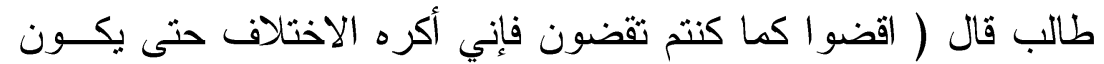

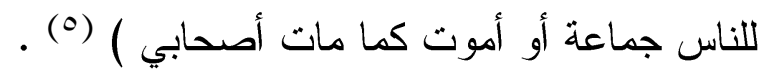

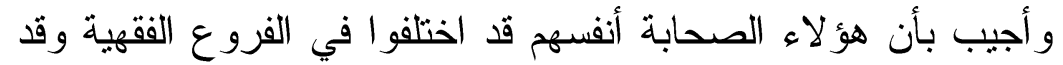

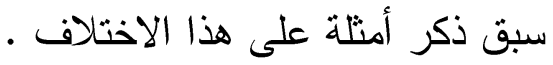

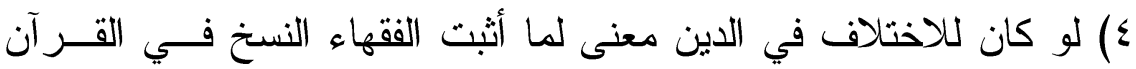
و السنة كما أن القول به يرفع باب الترجيح بين الأدلة المتعارضة (آ) .

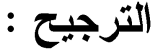

مما لاشك فيه أن كلا الفريقين يقر بأن الاختلاف قد وقع فعلا كما أنهم

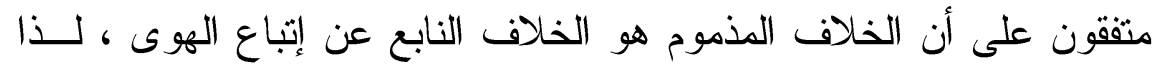
فإن الخلاف هنا شكليا وليس خلافا جوهريا . تعريف علم الاختلاف : علم يتوصل به إلى حفظ الأحكام المســتبطة المختلف فيها بين الأئمة أو هدمها لا إلى استتباطها (1) .

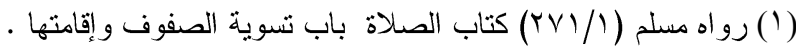

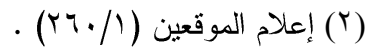
(؟) رواه البخاري كتاب الاعتصام بالكتاب و السنة باب الاقتداء بسنن رسول الله صلى الله عليه وسلم .

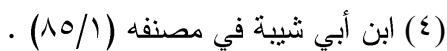

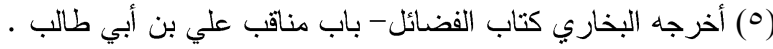

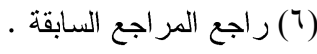


هو علم يعرف به كيفية إيراد الحجج الثرعية ودفع الثبهة وقـــوادح

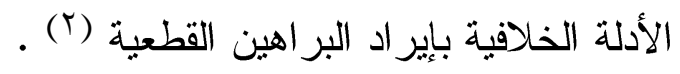

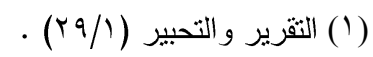

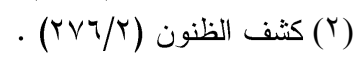




\section{المبحث الثاني \\ سبب النزول وأثره في اختلاف الفقهاي في أحكام المرأة \\ المطلب الأول: تعريف سبب النزول وأهميته}

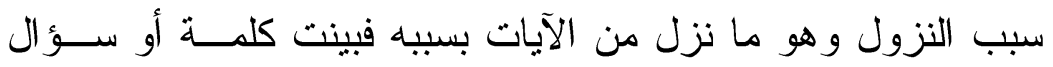

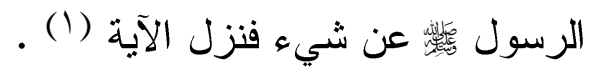

ومعنى هذا أن سبب النزول يعود إلى أحد أمرين الأول حدوث حادثة

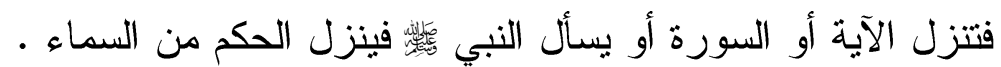

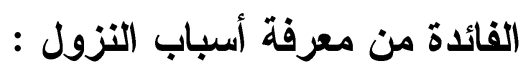

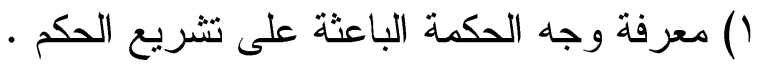

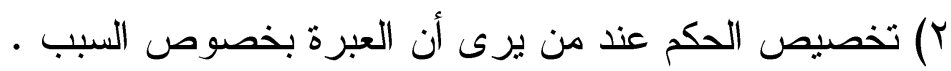

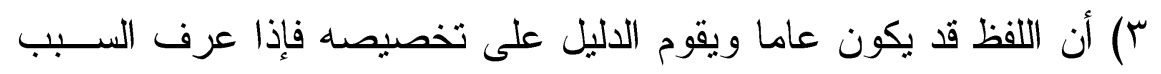
قصر التخصيص على ما عدا صورته فإن دخول صورة السبب قطعي

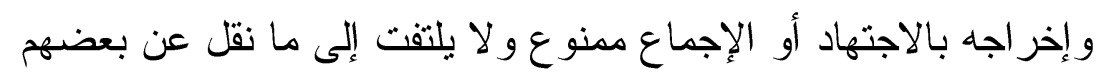

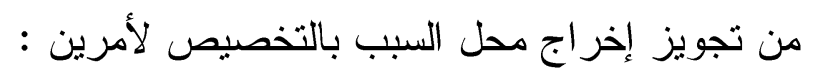

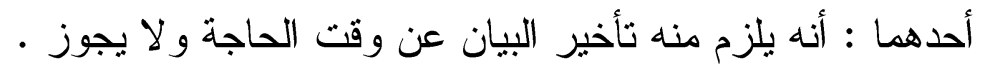

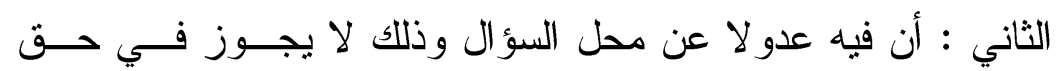

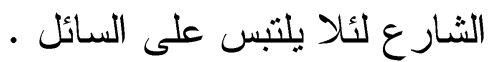

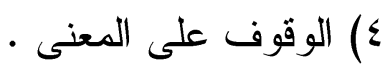

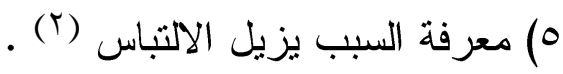

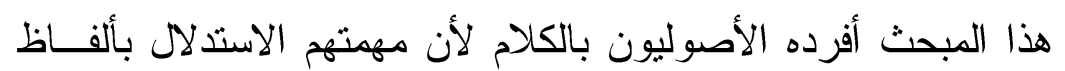
الثار ع على الأحكام ، وهو مع هذا وثيق الصلة بمباحث أسباب النزول(r).

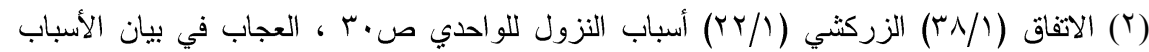
( ( 
ولا خلاف بين الفقهاء فى أن السبب إذا نزل فى العموم أو اتفق معه

فى الخصوص حمل العام على عمومه و الخاص على خصوصه (1) . (1)

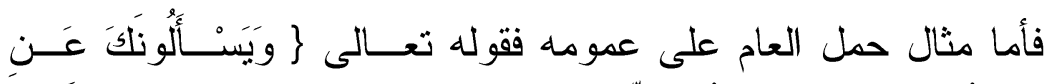

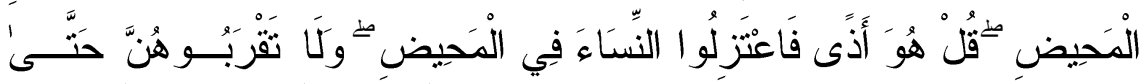

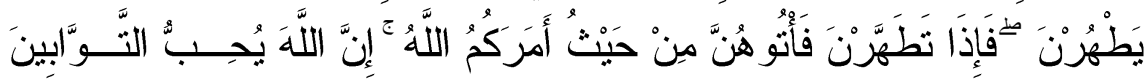

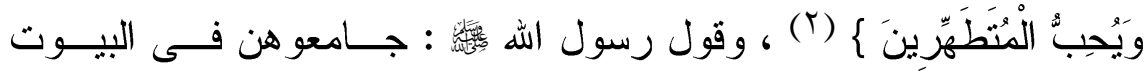
و اصنعو ا كل شئ إلا النكاح (r). أما مثل حمل الخاص على خصوصه بأن تنزل الآية فى معـين ورلا

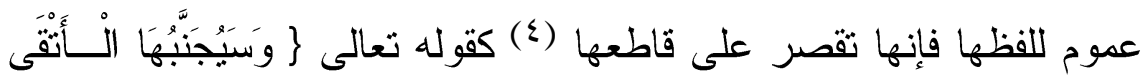

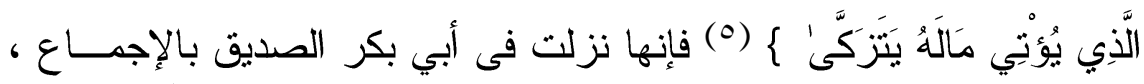

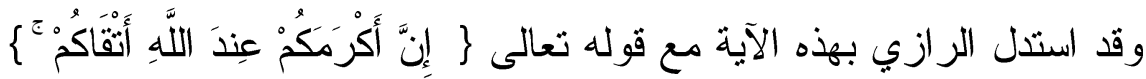

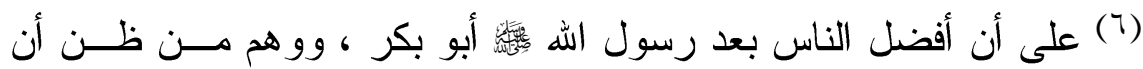

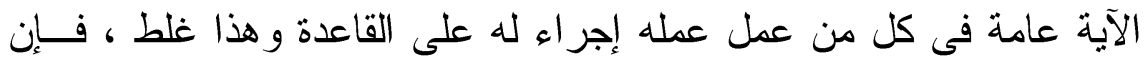

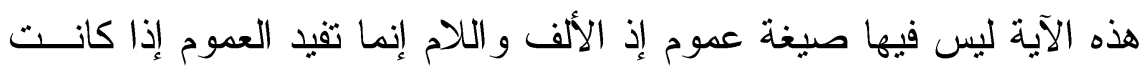

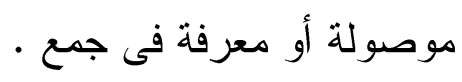

وز اد قوم : أو مفرد بشرط أن لا يكون هناك عهد و اللام فى الأتقـى

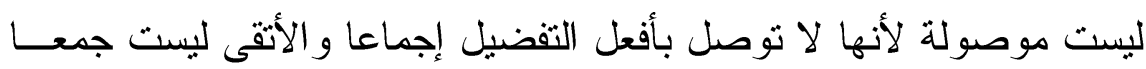
بل هي مفردة و العهد موجود خصوصا مع ما تفيده صيغة أفعل من التمييز

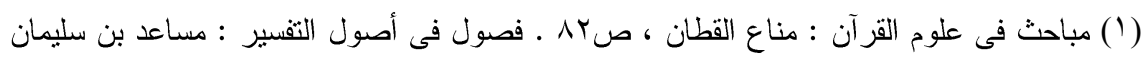

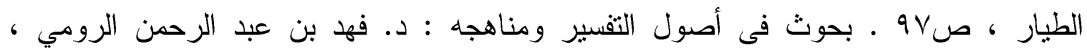

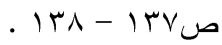

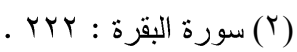

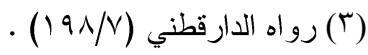

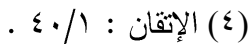


وقطع المشاركة فبطل القول بالعموم وتعين القطع بالخصوص والقصر على

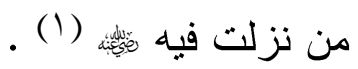

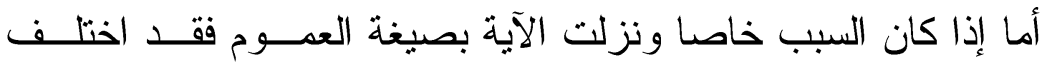

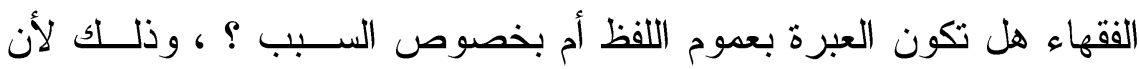

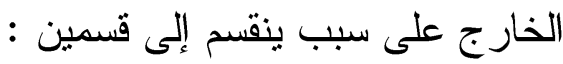

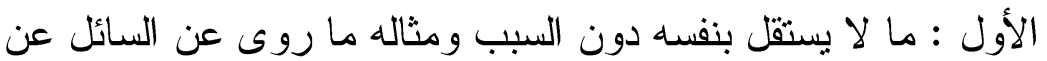

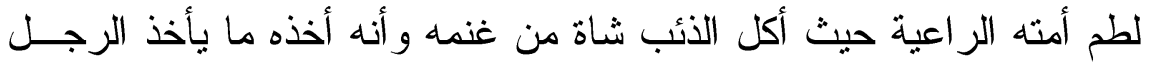
على تلف ماله (r) ، وكذا لو قال القائل : نوضأت بماء البحر فقال : يجزئك

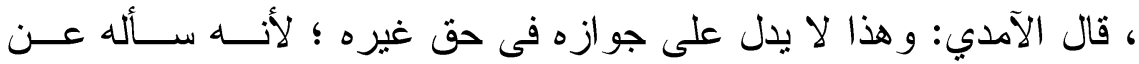

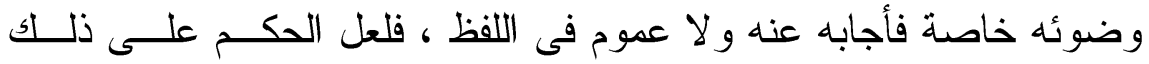
الثخص لمعنى يخصه وكذا تخصيص خزيمة بقبول شهادته وحده ، ومسـن

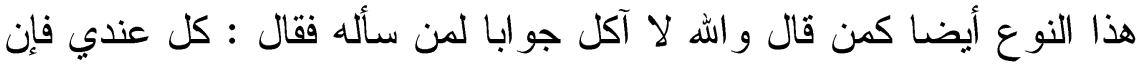
العرف يقتضي عرف السؤال على الجواب فلا يحنث إلا بالأكل عنده (r) .

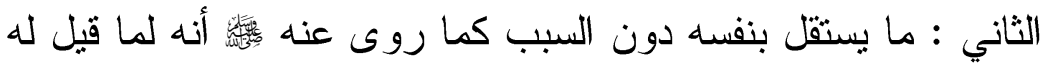
: إنك تتوضأ من بئر بضاعة وهي تطرح فيها الحيض ولحوم الكلاب و النتن

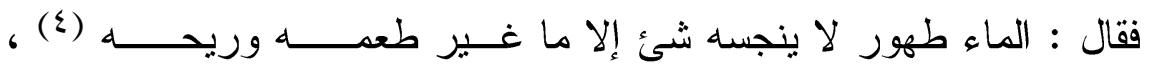
فحكم هذا فى استقلاله بنفس حكم القول المبتدأ (0) .

(r) الواضح من أصول الفقه ، لأبي الوفاء علي بن عقيل بن محمد الحنبلي ، تحقيق د. عبد الله بن عبد

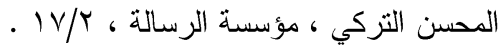

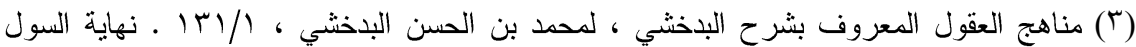

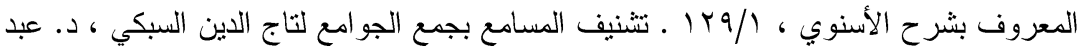

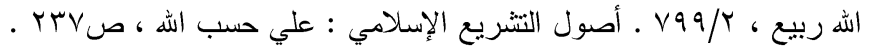

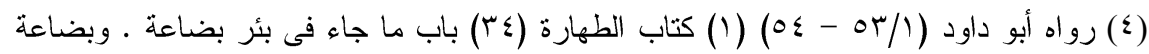

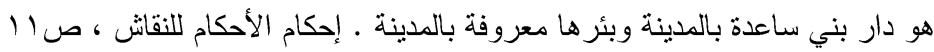

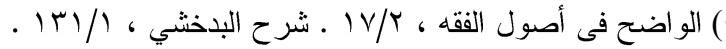


وهذا النوع هو المطلوب وهو المقصود عند قولنا : العبــرة بعدــوم اللفظ أم بخصوص السبب ؟ وقد اختلف الفقهاء فى هذا النوع إلــى فــــيقين هما:

الفريق الأول : ويمثله جمــهور العلمــاء القائلين بأن العبرة بعدــوم اللفــ لا بخصوص السبب (1) : (1) المطلب الثاني: القصر للخائف فى السفر

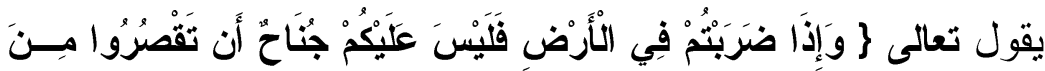

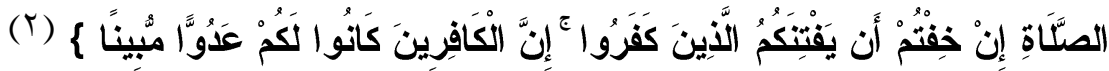

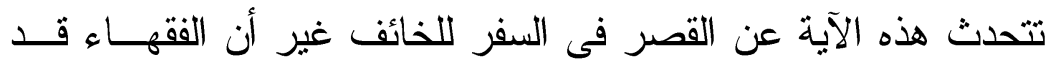
اختلفو ا فى اشتر اط الخوف مع السفر لقصر الصلاة إلى مذهبين وبيانهما كما يلي:

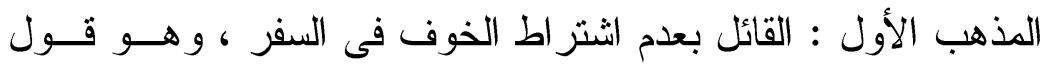

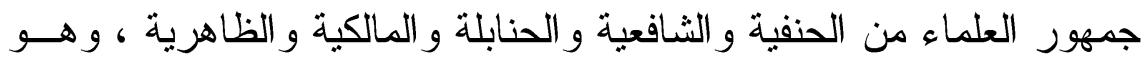
قول جل الصحابة (r) وقد استدلو اعلى جواز ذلك بعدة أدلة وهي :

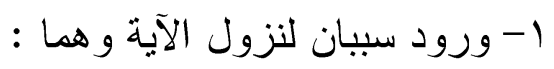
أ- فعن علي بن أبي طالب قال : سأل قوم من التجار رسول الله

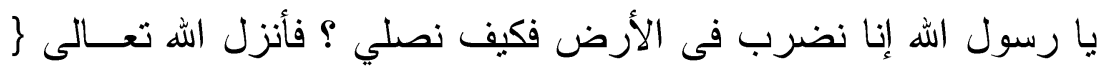

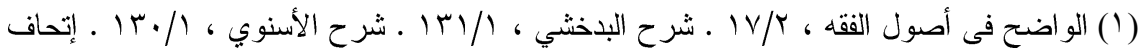

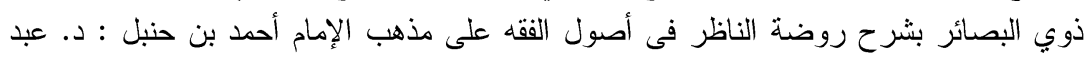

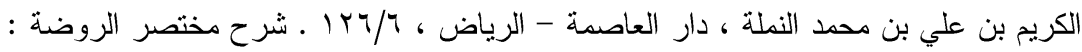

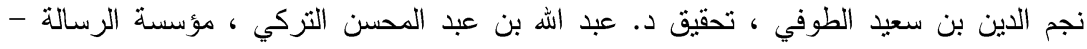

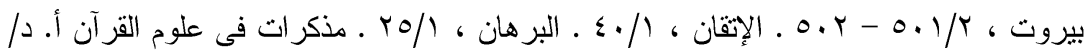

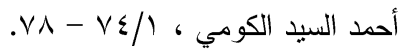

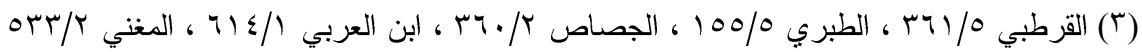

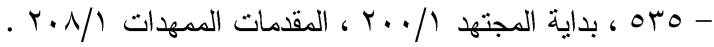




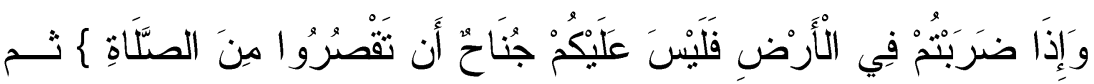

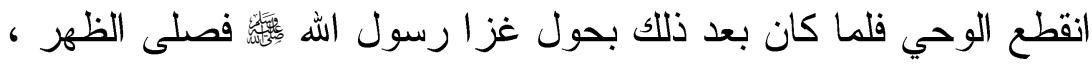

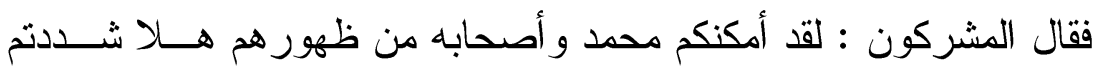

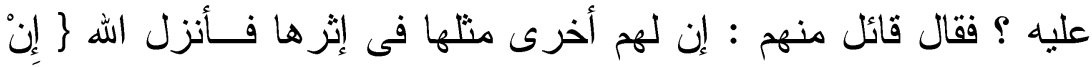

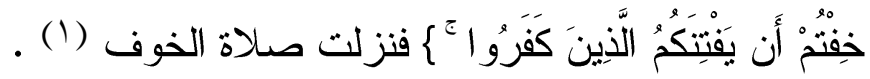

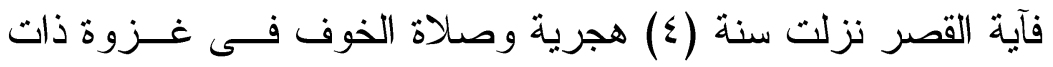

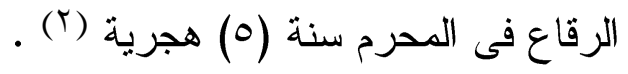

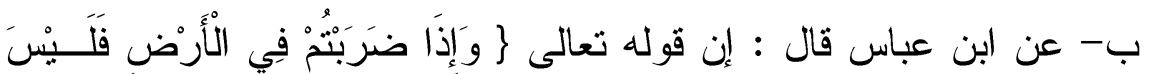

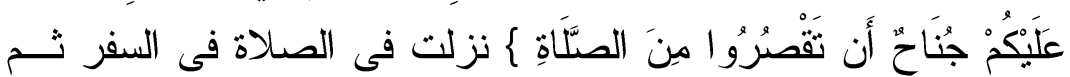

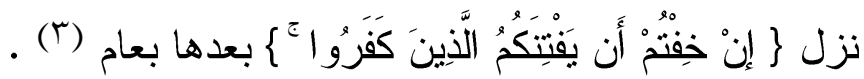

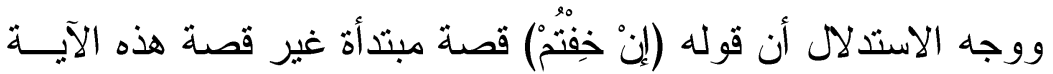

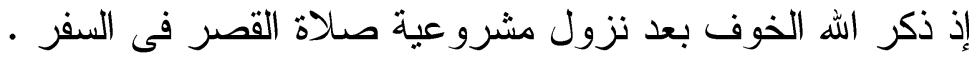

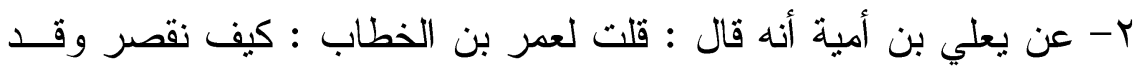

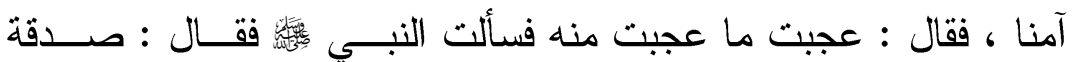
تصدق الله بها عليكم فاقبلو ا صدقته (ع) .

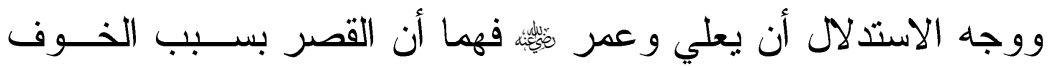

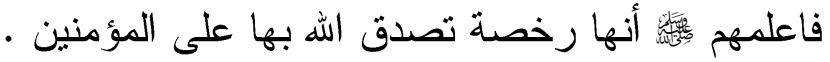

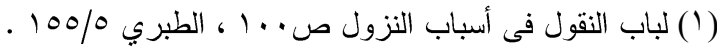

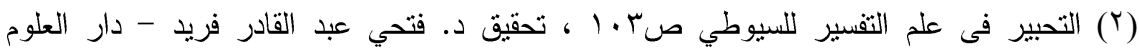

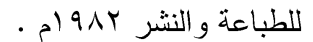

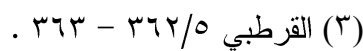

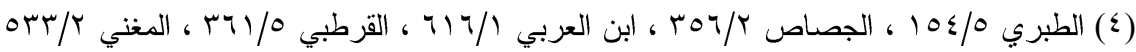

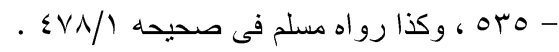




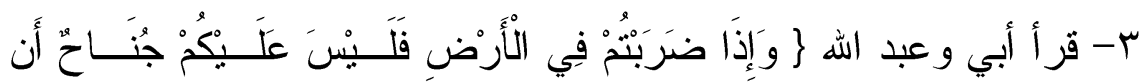

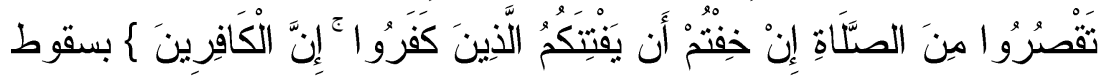

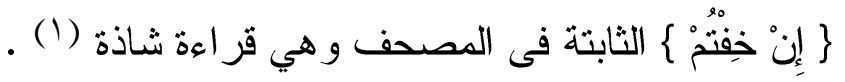

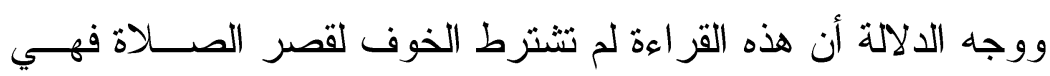

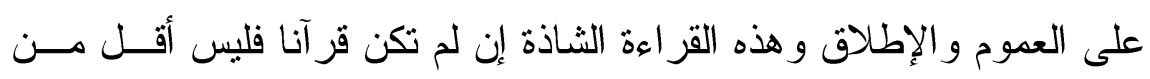

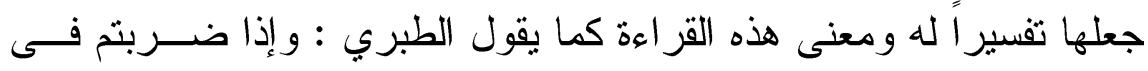
الأرض فليس عليكم جناح أن تقصروا من الصلاة أن لا يفتنكم الذين كفروا

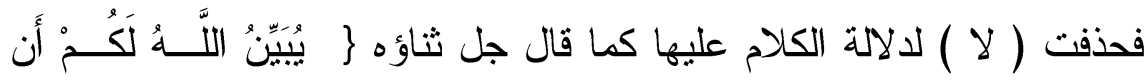

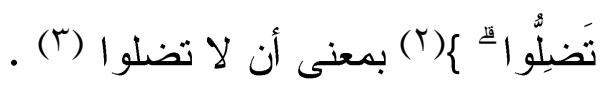

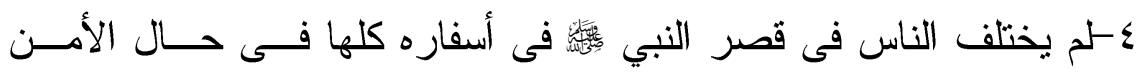

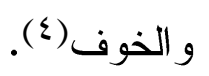

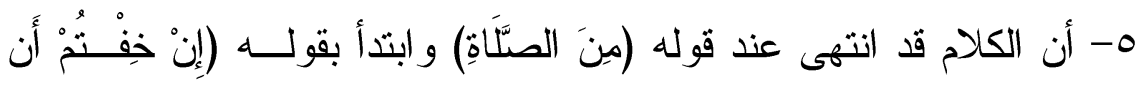

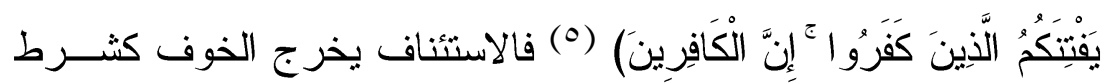

$$
\text { للقصر فى السفر لفنئن }
$$

المذهب الثاني القائل : بأن القصر فى السفر يشترط فيه الخوف وهو

قول عائشة وسعد بن أبي وقاص (T) .

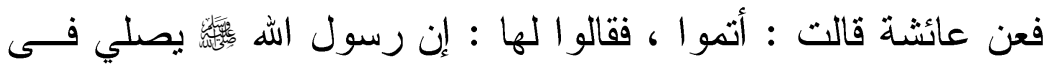

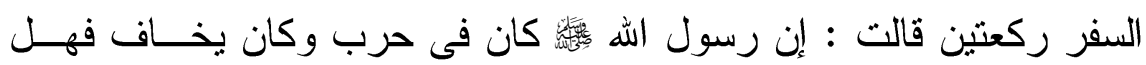
تخافون أنتم ؟ (V) ( 
وعن ابن جريج قال : قلت لعطاء : أي أصحاب رسول الله

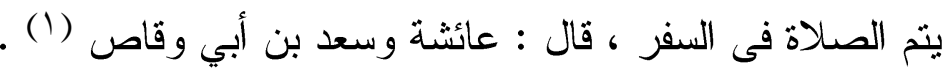

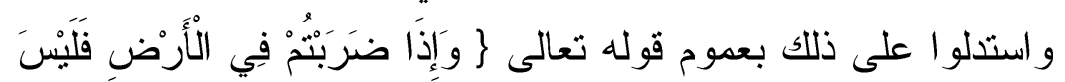

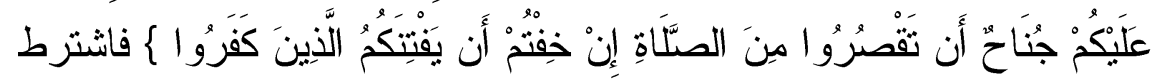
فى القصر الخوف .

\section{تعقيب وترجيح :}

بعد عرض أدلة كل منهما تبين لنا قوة أدلة الجمهــور القائـلـل بعـدم

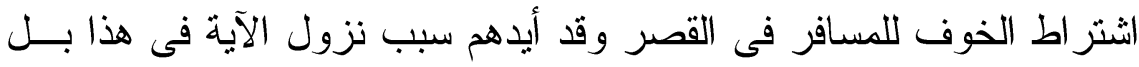
وقد ثبت عن عائشة أنها قالت : اعتمرت مع رسول الله مكة حتى إذا قدمت مكة قلت : يا رسول الله

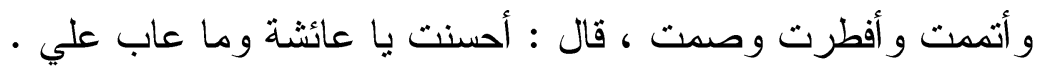

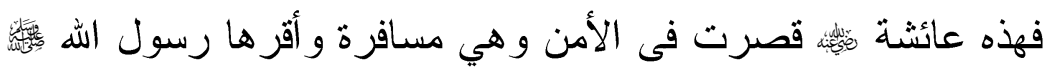
على ذلك (r) . كما روي عن ابن عمر أنه فال : صحبث النبي

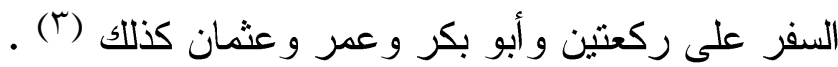




\section{المطلب الثالث}

سبب النزول وأثره في اختلاف الفقهاء في إتيان النساء في الدابر

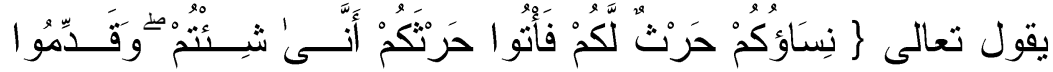

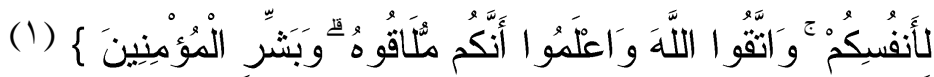

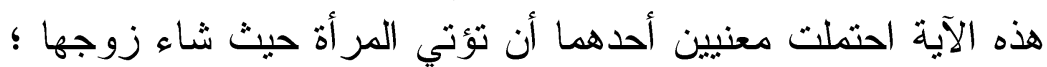

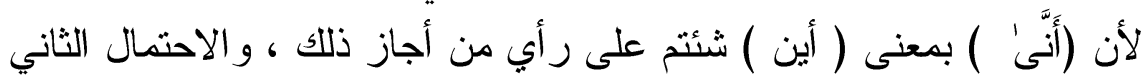

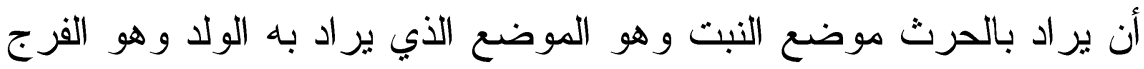

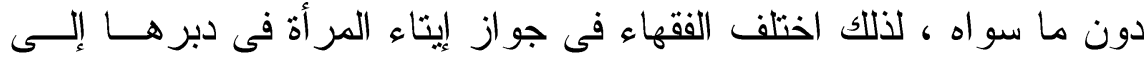

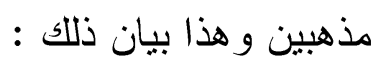

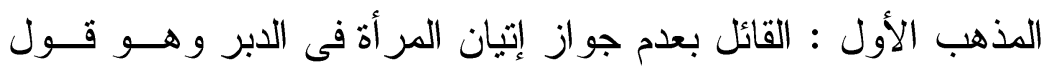

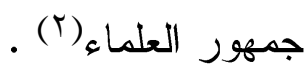

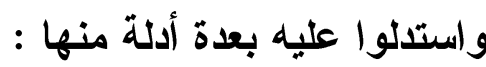

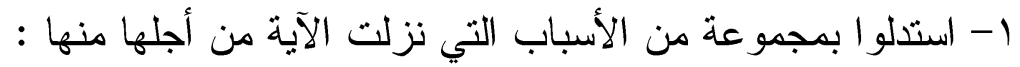

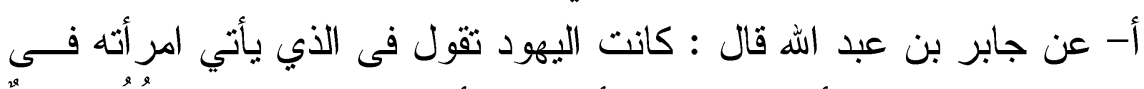

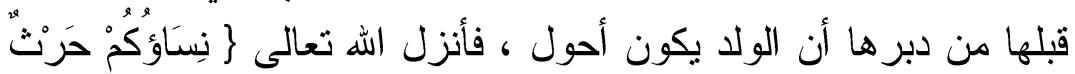

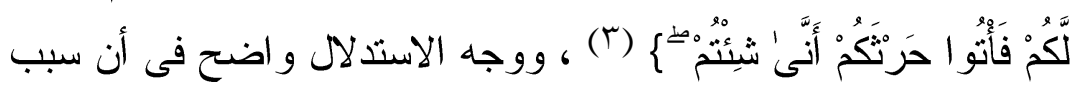

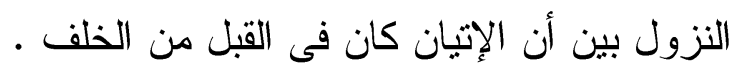

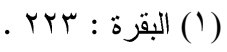

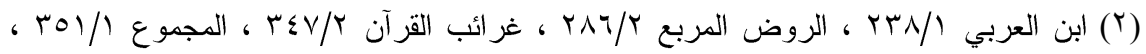

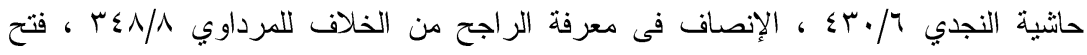

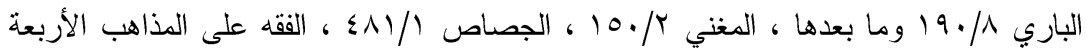

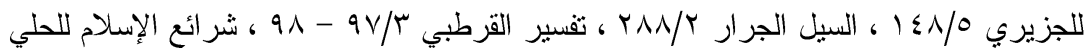

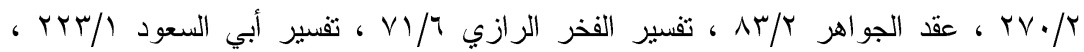

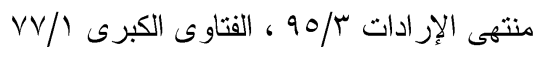

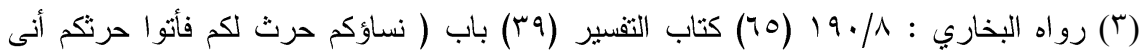

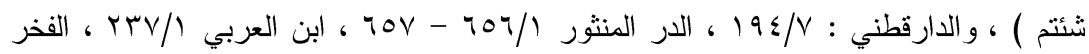

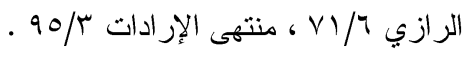




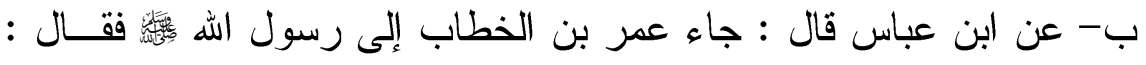

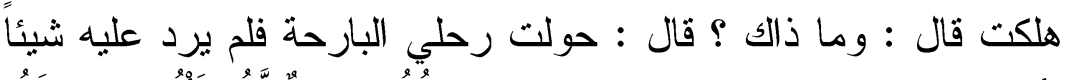

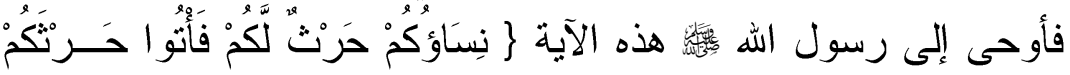

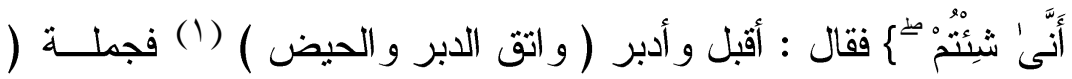

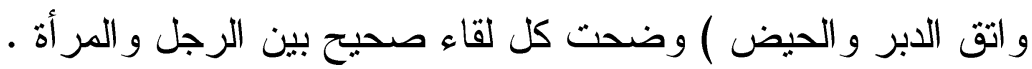

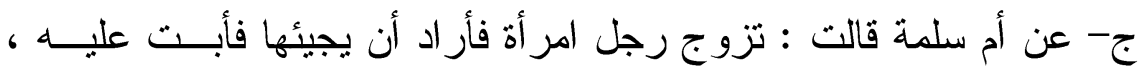

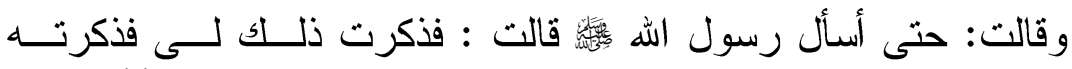

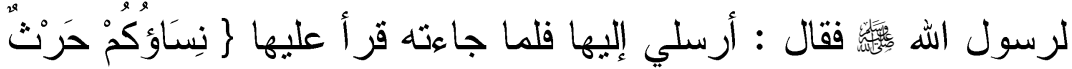

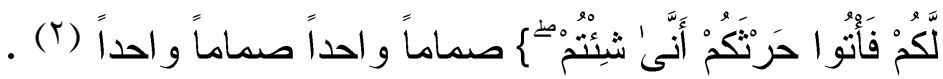

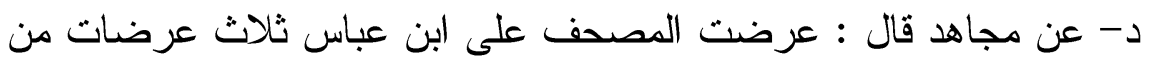

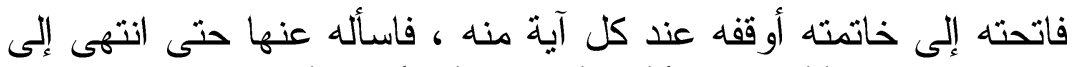

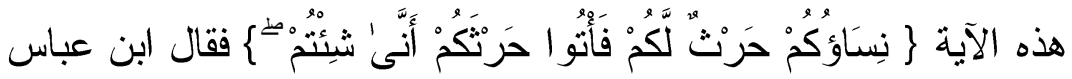

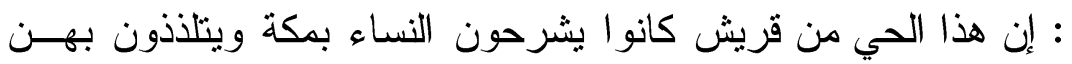

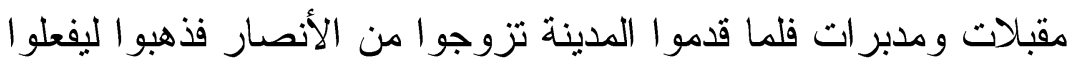

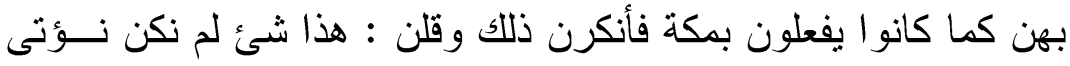

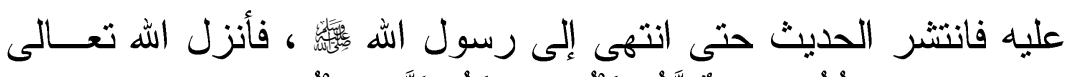

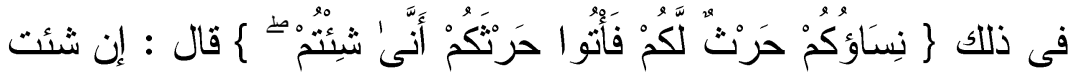

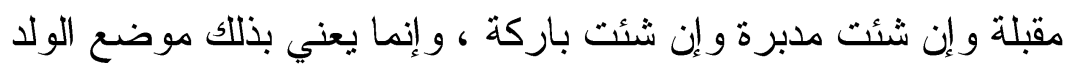

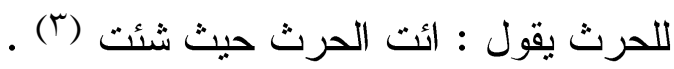

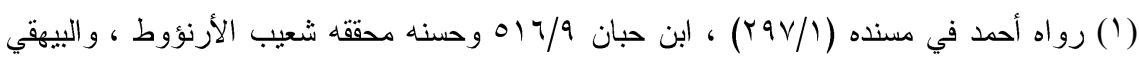
. (19//v)

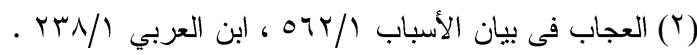

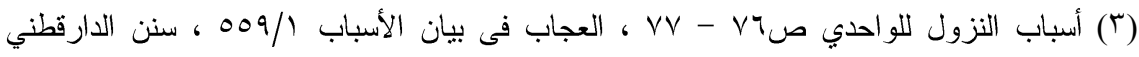

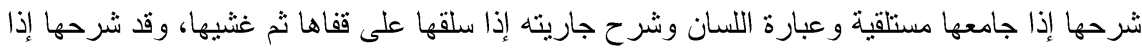

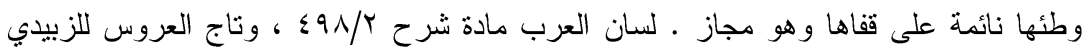

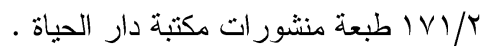


هـ-- عن أبي نضر أنه قال لنافع مولى ابن عمر : إنه قد أكثر عليك القول

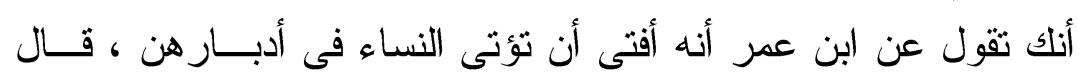

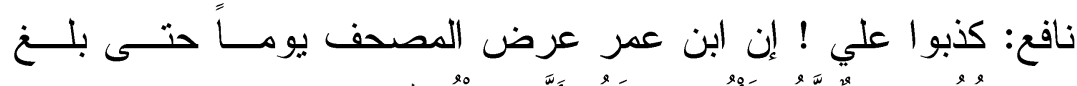

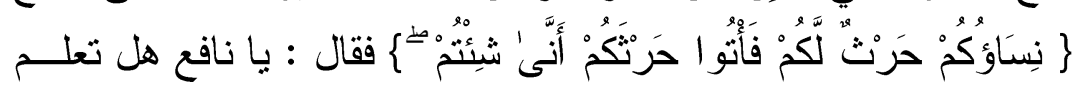

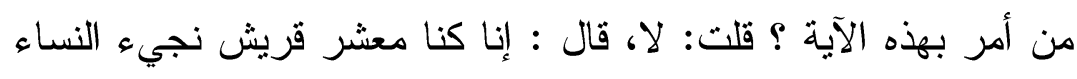

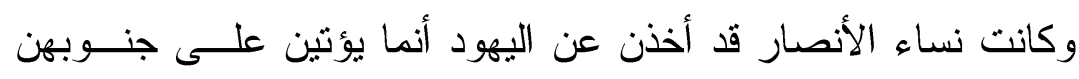

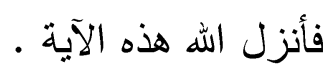

قال الجصاص : فهذا يدل على أن السبب غير ما ذكره زيد بن أســلم

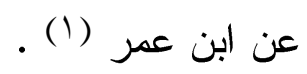

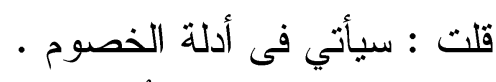

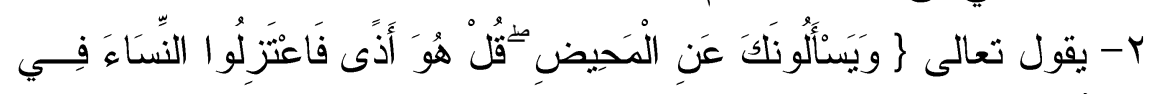

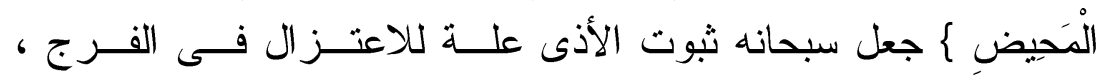

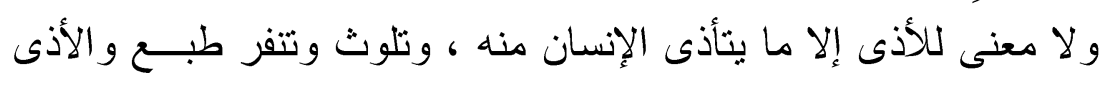

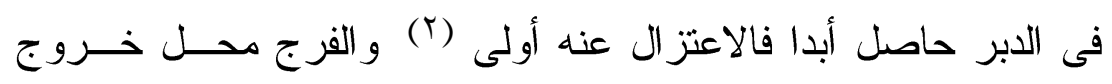

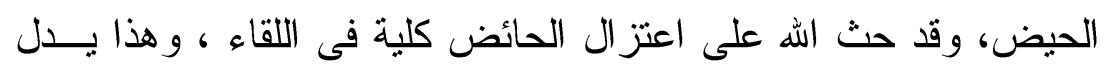

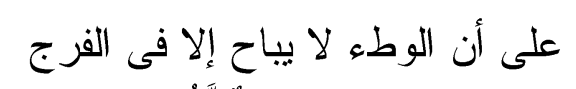

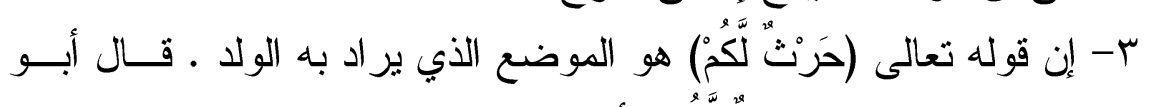

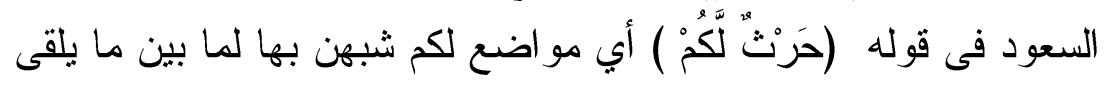

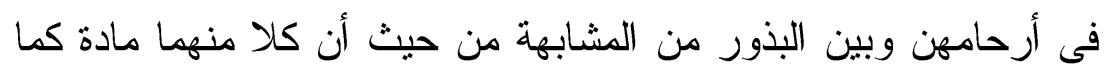

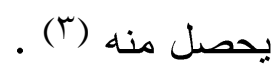




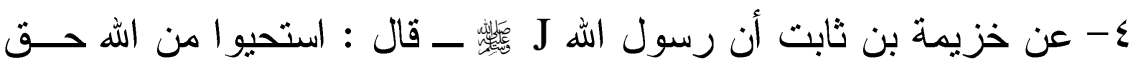

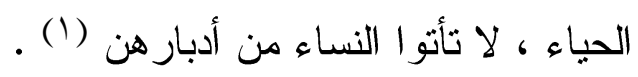

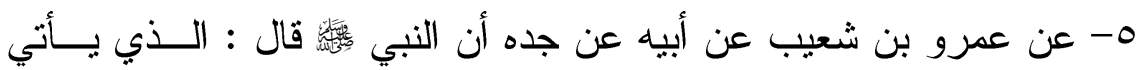

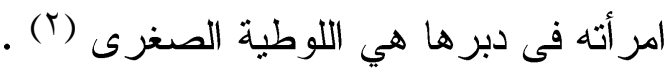

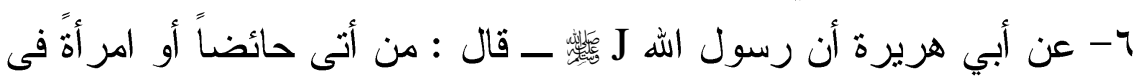

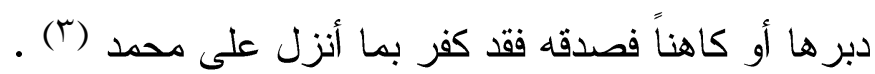

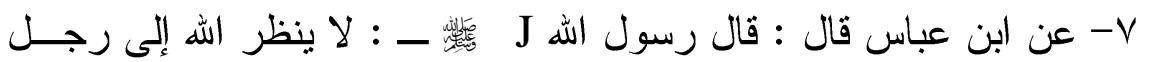

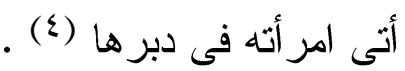

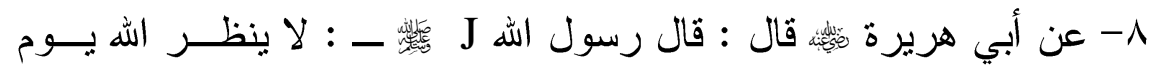

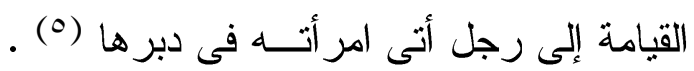

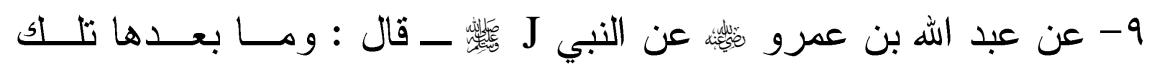

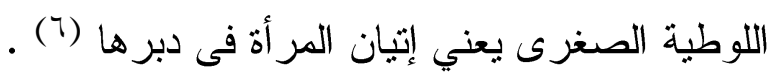

.

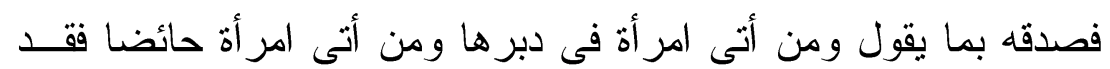

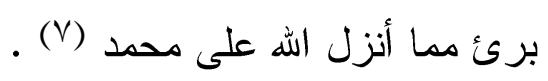

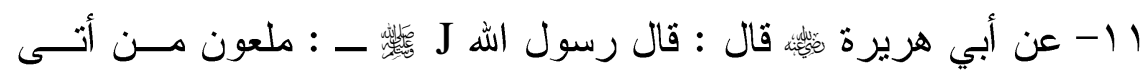

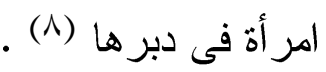

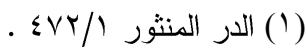

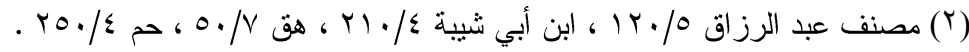

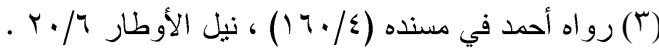

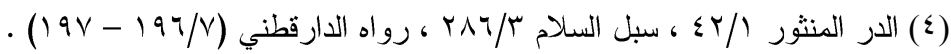

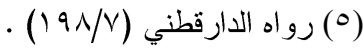

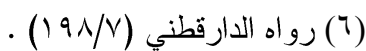

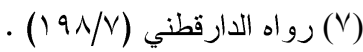

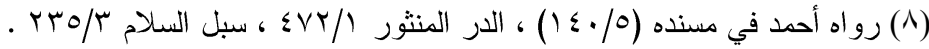




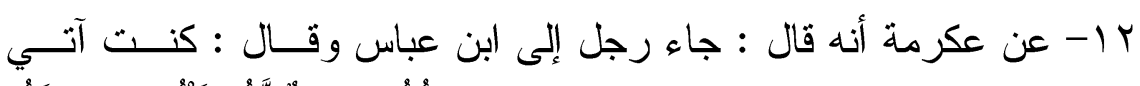

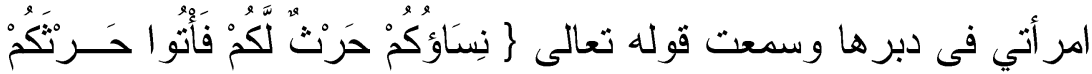

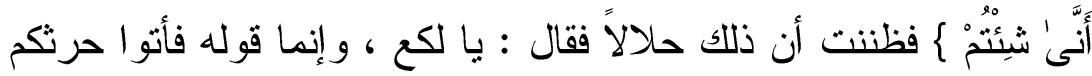

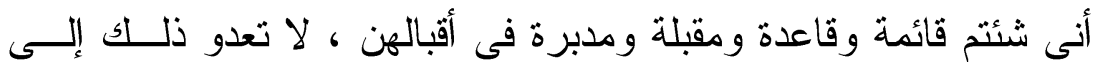

$$
\text { غيره(1) (1) }
$$

القول الثاني : القائل بجواز ذلك وهو مروي عن محمد بـن كعـب

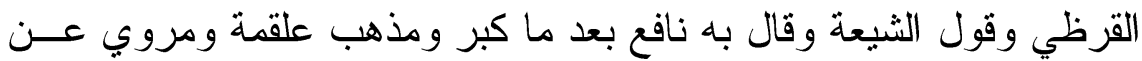
مالك و أنكره أصحابه ومروي عن ابن عمر ونفاه نافع (r) .

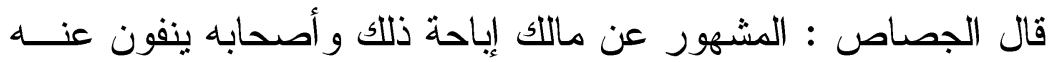
هذه المقولة لقبحها وشناعتها وهي عنه أثنهر من أن يندفع بنفيهم عنه (r) .

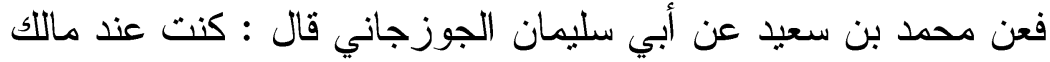

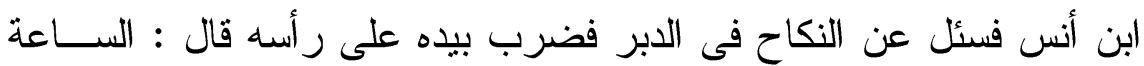
اغتسلت منه ـ وقد رو اه عن ابن القاسم (ع) . وقد تمسك متأخروا المالكية برو اية إسر ائيل بن رو احة عن مالك بــن

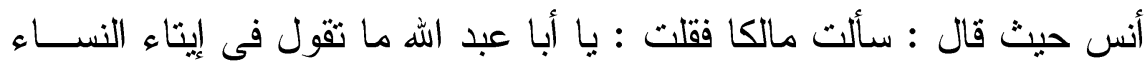

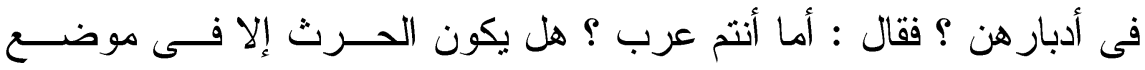

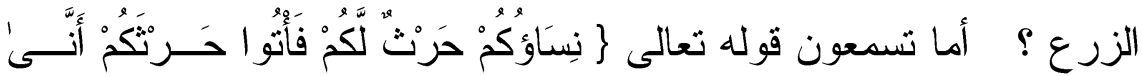

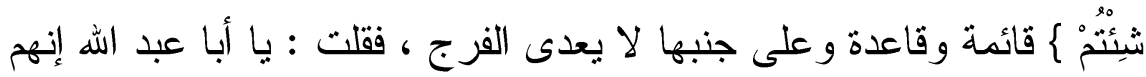
يقولون أنك تقول بذلك ، قال : يكذبون علىَّ يكذبون علىَ يكذبون عليَّ (0) . 


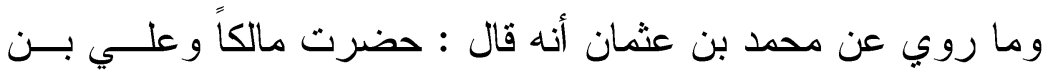

زياد يسأله فقال : عندنا يا أبا عبد الله قوم بمصر يحدثون عنك أنكان أنك تجيـز

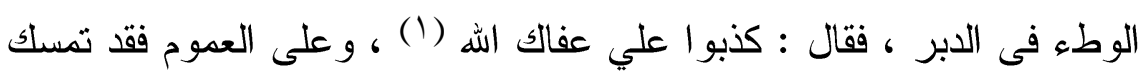

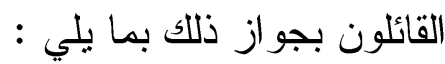

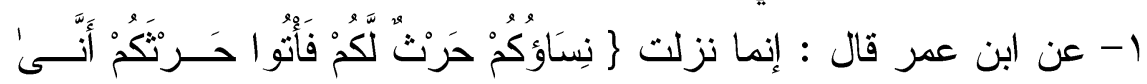

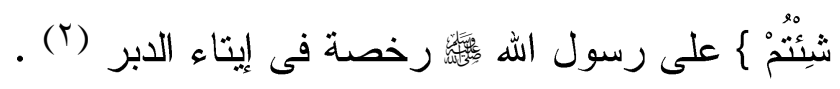

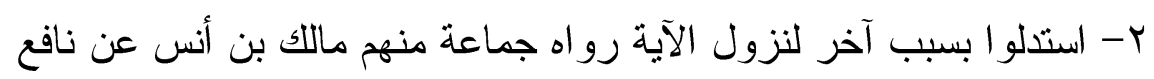

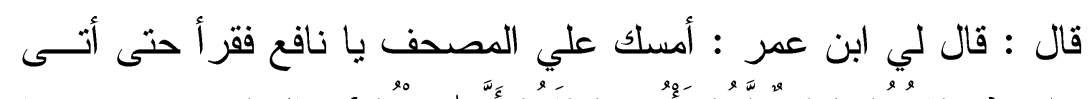

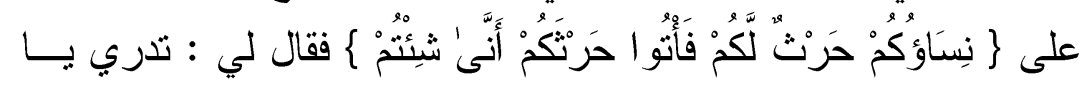

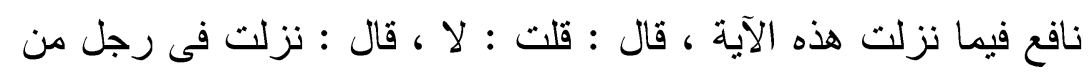

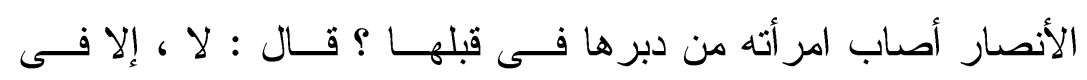

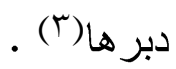

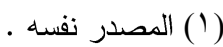

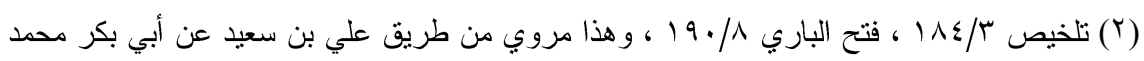

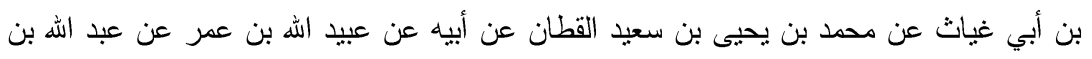

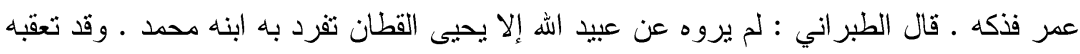

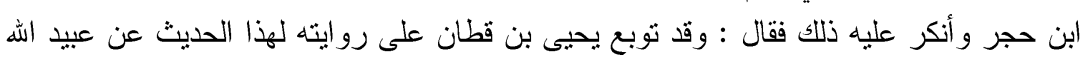

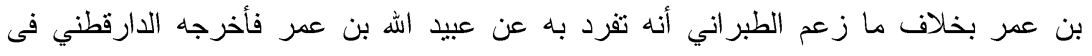

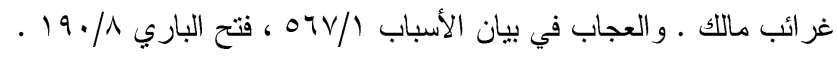

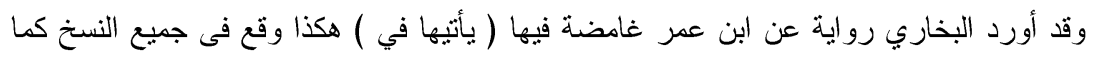

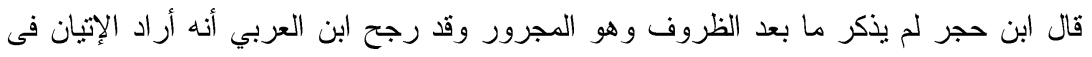

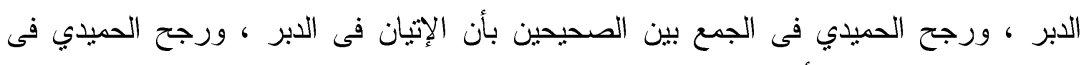

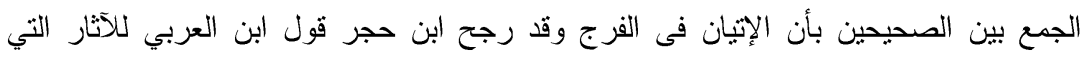

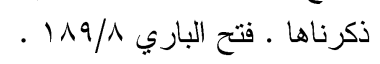
وقد عاب الإسماعيلي صنيع البخاري هذا ، فلقال الهال : جميع ما أخرج عن ابن عمر مبهم لا فائدة فيه

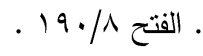
وقد أنكر ابن عباس على ابن عمر قوله بجواز الوطء فيى الدبر ونسبه إلى الوهم فى الفهر .

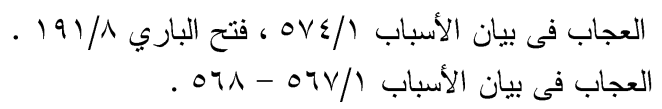




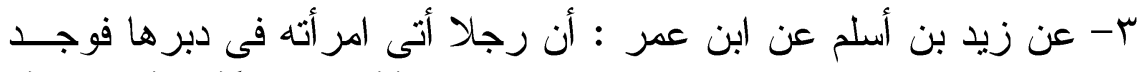

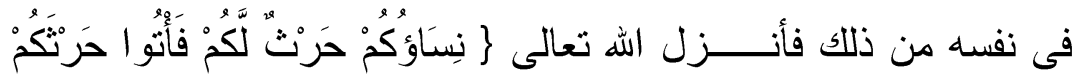

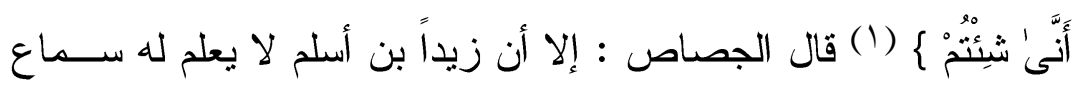

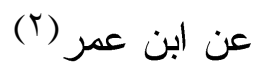

ع- أن ( الحرث ) الدذكور هنا اسم المر أة لا الموضع المعين و إلا لعد إيتاء

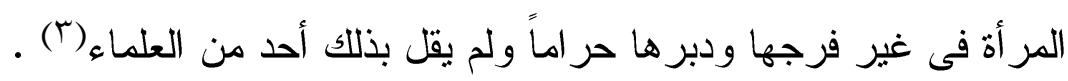

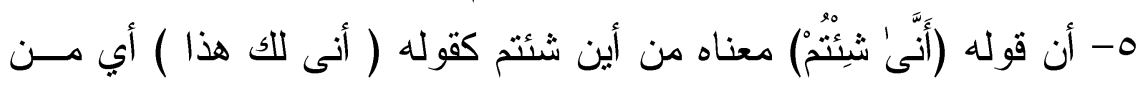

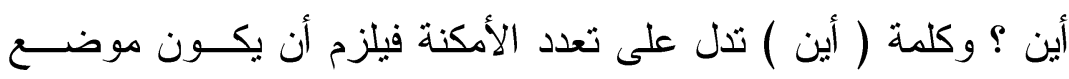

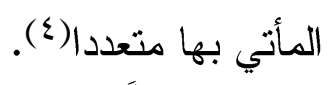

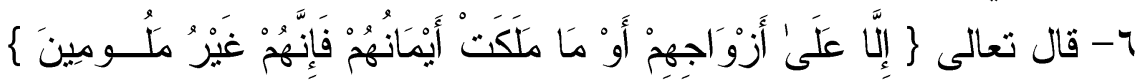

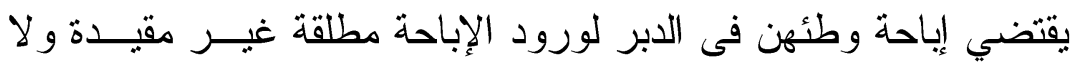

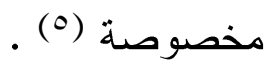

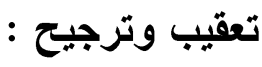

بعد عرض الآراء يتبين لنا قوة أدلة الجمهور الأخذين بسبب نــزول ألئل

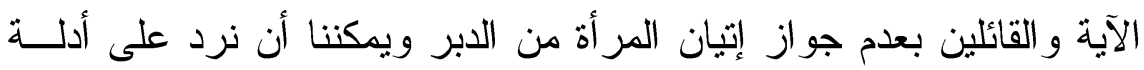

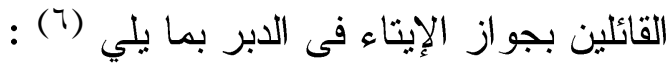

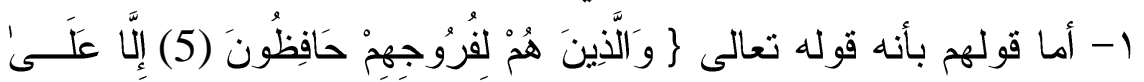

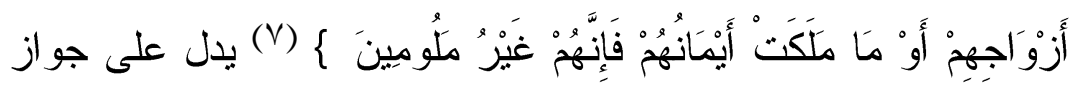

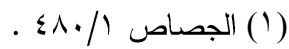

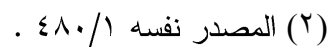

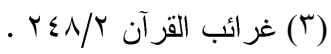

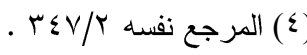

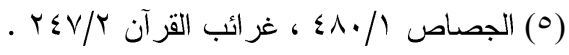

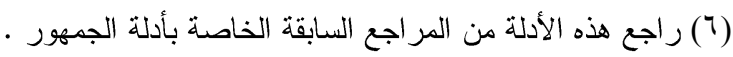

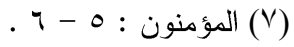


الوطء فى الدبر لورود الإباحة مطلقة غير مقيدة و لا مخصوصة فهـذا

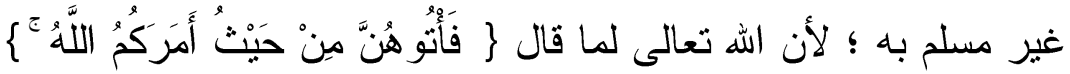

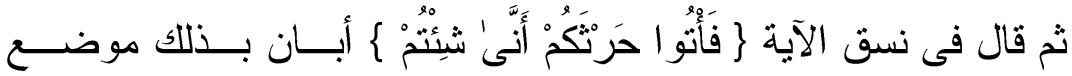

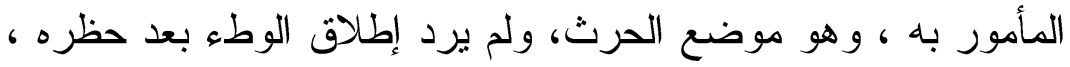

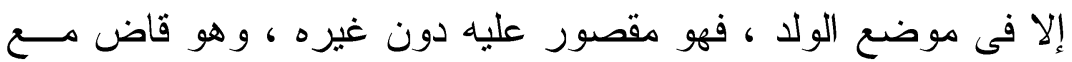

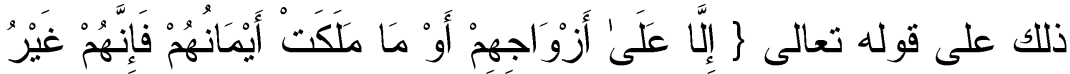
مَلْو مِينَ $\{$.

r- أما قولهج بأن الحرث اسم المرأة لا الموضع المعين فهذا غير صحيح ؛

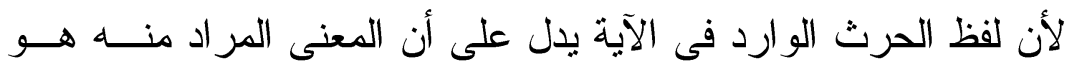
الفرج ، إذ هو المزروع • يقول الثاعر (1) : (1)

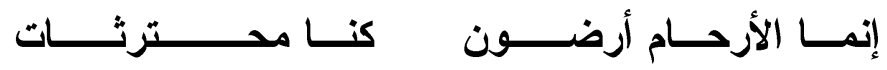

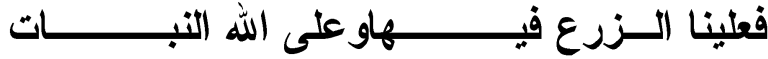
ففرج المر أة كالأرض و النطفة كالبذر و الولد كالنبات فالحرث بمعنى لهـ المترث

r- أما قولهم بأن ( أنى شئتم ) بمعنى أين شئتم ، فهذا غير مسلم به أيضا ؛

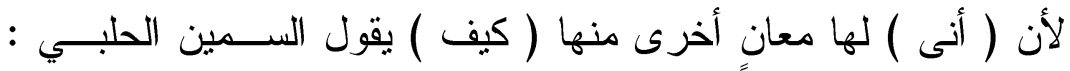

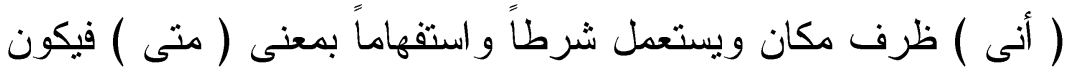
ظرف زمان ويكون بمعنى ( كيف ) وبمعنى ( من أين ) وقد فسـرت

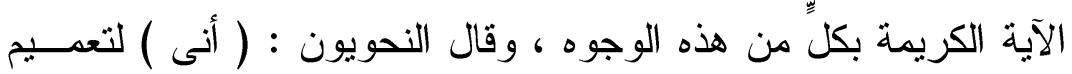

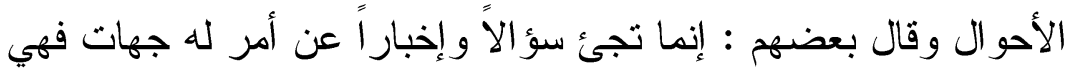
على هذا أعم من ( كيف ) ومن ( أين ) ومن ( متى ) (r) وقـــد ورد

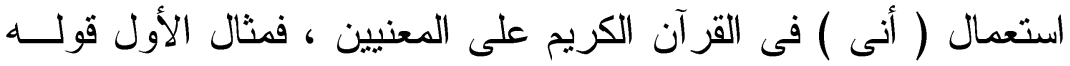




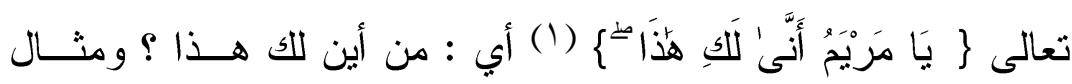

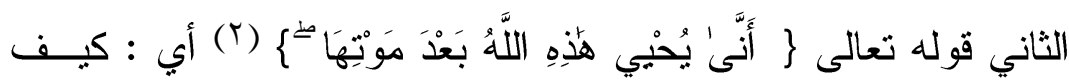

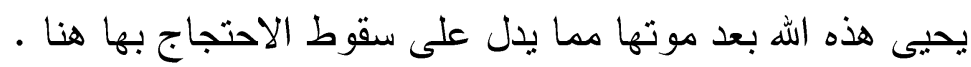

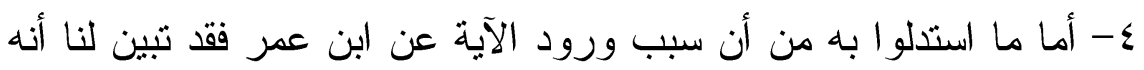

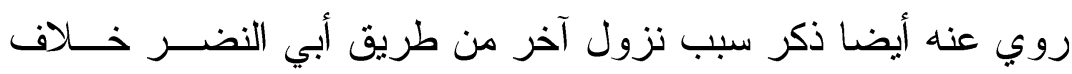

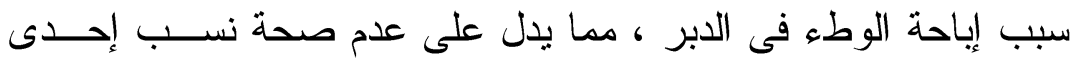

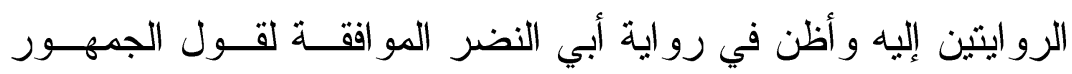

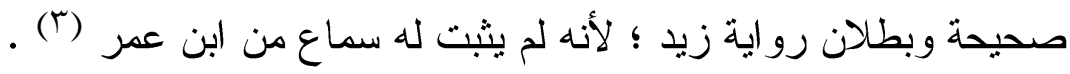

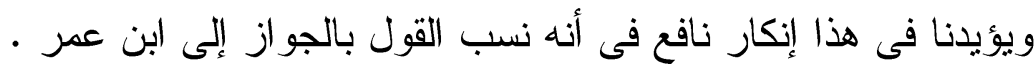

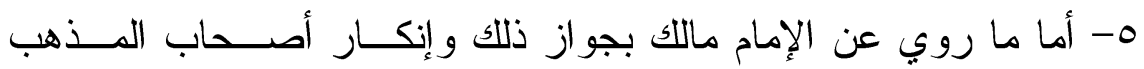

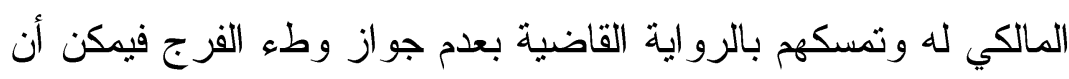

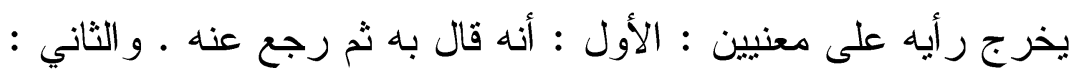

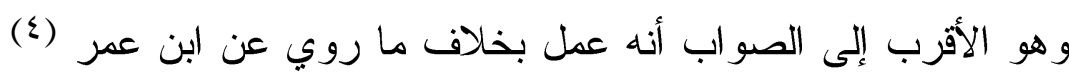

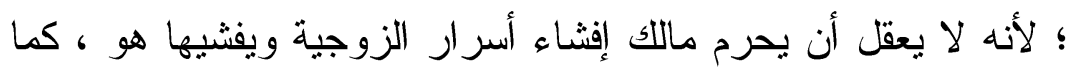

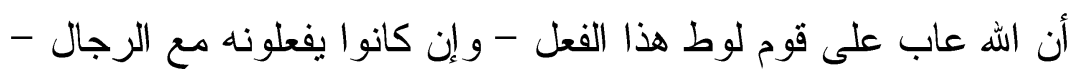

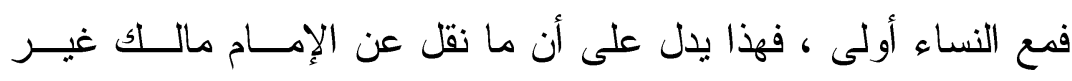

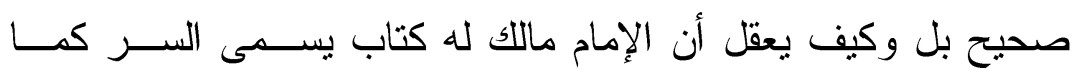

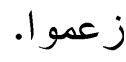

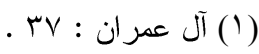

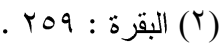

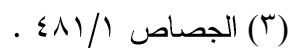

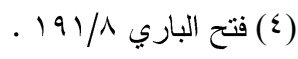


7- لو سلمنا مساو اة أدلة المجيزين بأدلة المانعين فى القوة فالاجتتاب أحوط

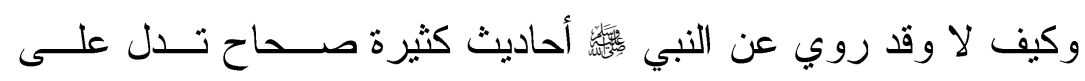

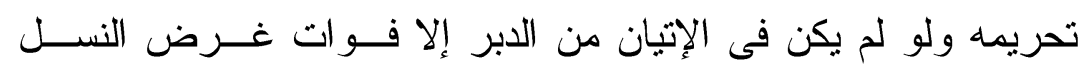

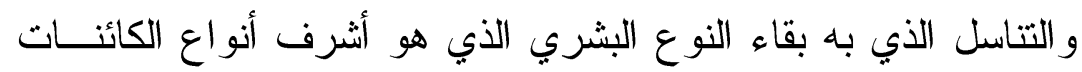

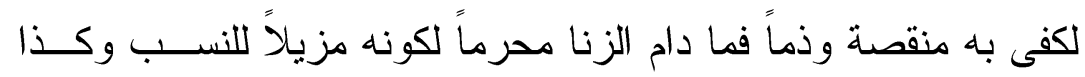

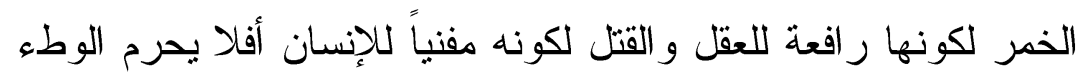
فى الدبر لكونه منضمناً للفناء .

نخلص من ذلك كله إلى القول بتحريم الوطء فى الدبر ولو ثبث أن ما أســـــ

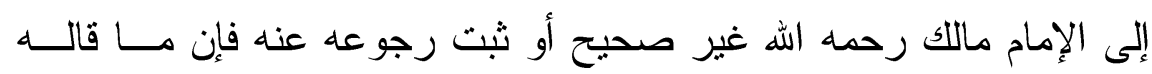
متأخرو المالكية من عدم جواز الوطء من الخلف يرفع الخلاف بين علمــاء

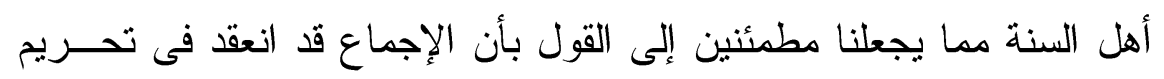

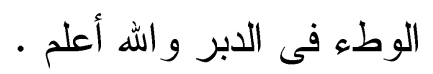




\section{المطلب الرابع}

\section{سبب النزول وأثره في اختلاف الفقهاء في الولاية فى الزواج على المرأة البَالغة}

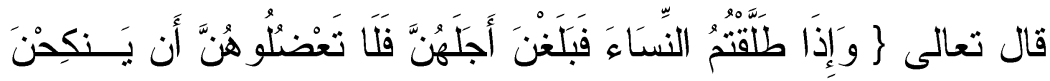

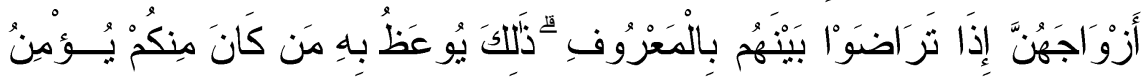

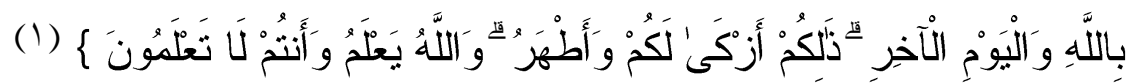

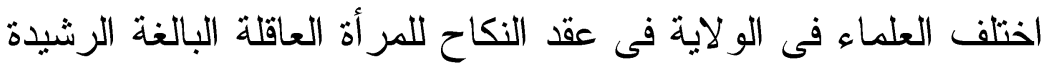

$$
\text { البكر إلى عدة مذاهب و إليك بيان ذللك : }
$$

المذهب الأول : هم القائلون بعدم جواز تولية المرأة ، فالمر أة لا تملك ذإن

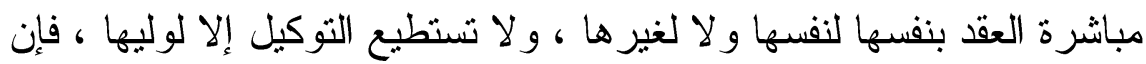
فعلت شيئا من هذا كان العقد باطلا ، وبهذا قال المالكية مو الشافعية و الحنابلة

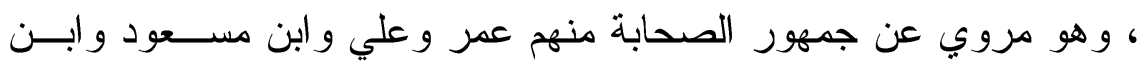

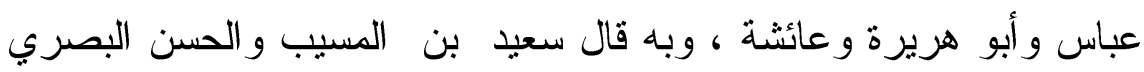

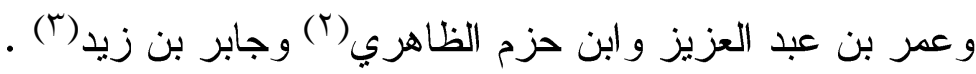

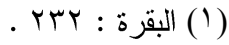

و العضل له معنيان : أحدها المنع والآخر الضيق يقال : عضل القضاء بالجيش إذا ضاق به والأمر

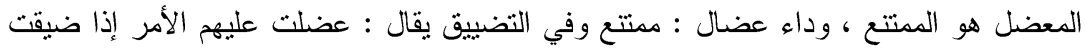

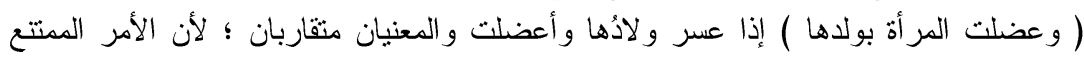

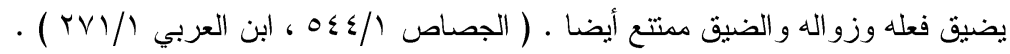

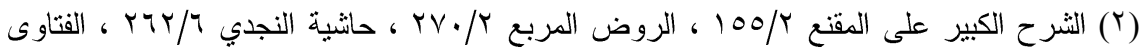
الكبرى

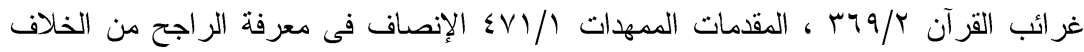

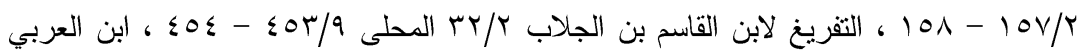

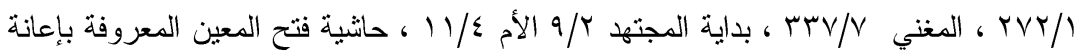

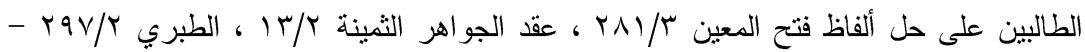

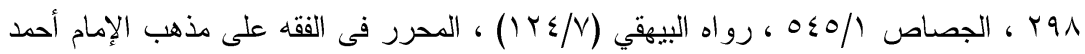

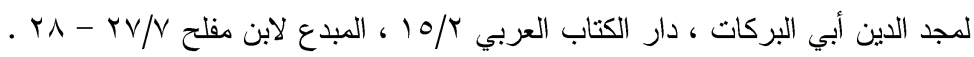

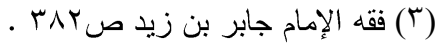


واستدلوا على ذلتك بأدلة من المنقول ومن المعقول :

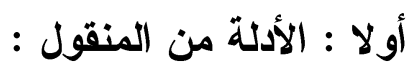

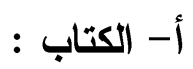

1- استخلو ا بسبب نزول الآية المذكورة فقد روى البخاري وغيــره ســبيين

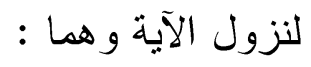

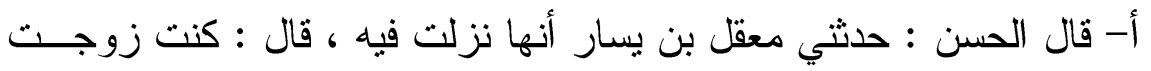

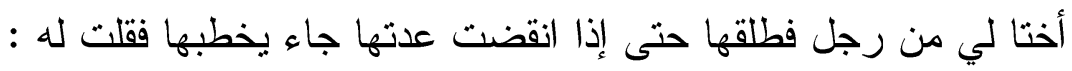

زوجتلك و أفرشتك و أكرمتلك فطلقتها ثم جئت تخطبها ؟ لا و الله لا تعود

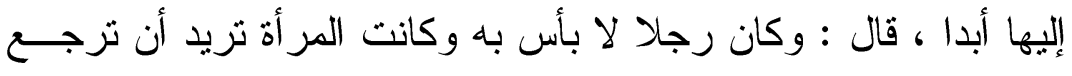

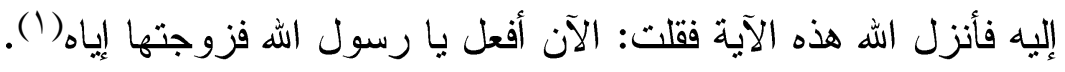

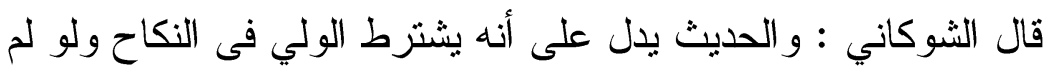

يكن شرطا لكان رغوب الرجل فى زوجته ورغوبها فيه كافيا (r) .

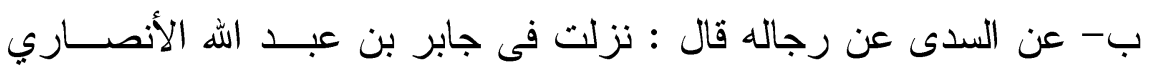

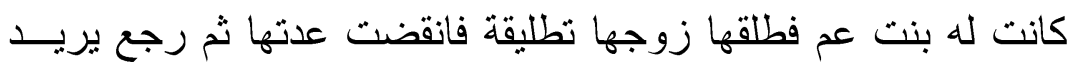
رجعتها فأبى جابر ، وقال : طلقت ابنة عمنا ثم تريد أن تتححها الثانية،

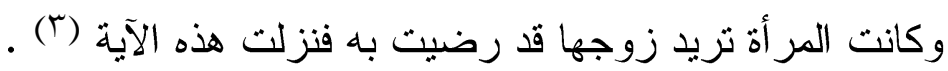

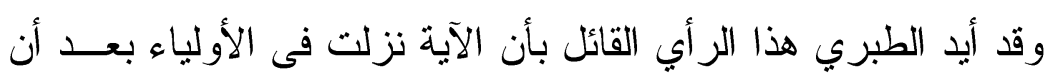

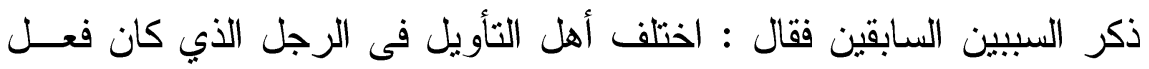
ذلك فنزلت هذه الآية فقال بعضهم : معقل بــن يســار المزنــي .... وقــال آخرون: كان ذلك الرجل جابر بن عبد الله ... و الصواب من القول في هذه لهذ

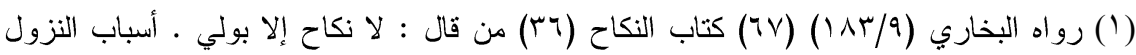

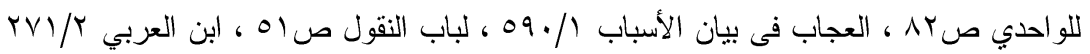

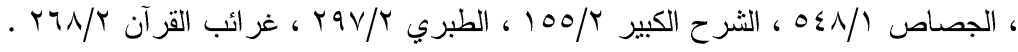

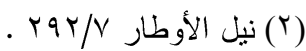

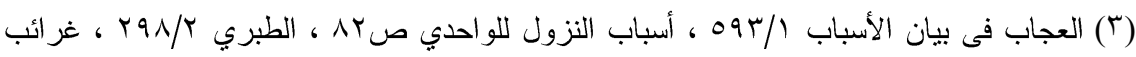

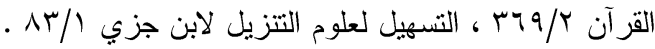


الآية أن يقال إن الله تعالى ذكره أنزلها دلالة على تحريمه على أولياء النساء

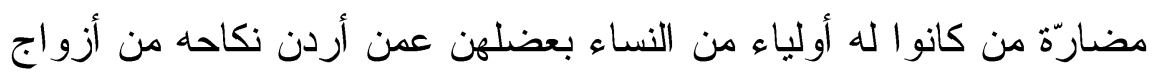

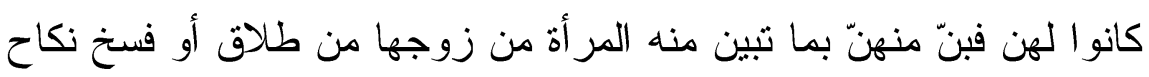

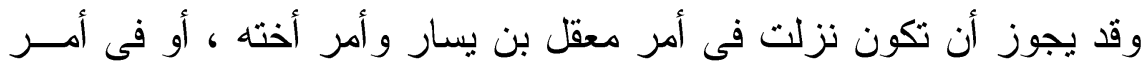

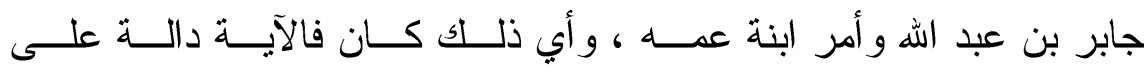

$$
\text { ما ذكرت (1) }
$$

وقد أجاب خصومهم بأن الخطاب فى الآية يدل على أن الولي شــرط

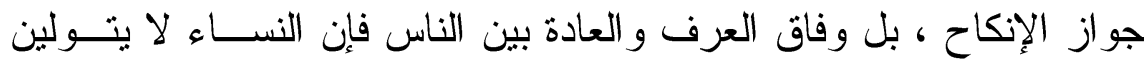

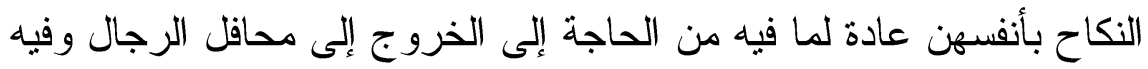

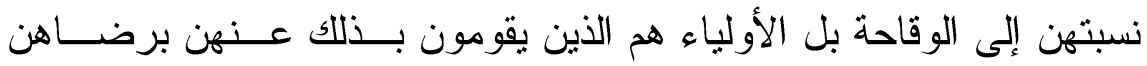

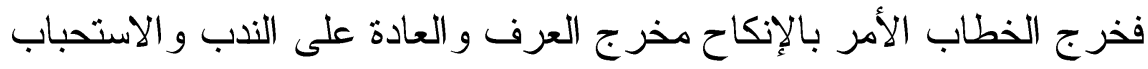

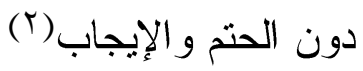

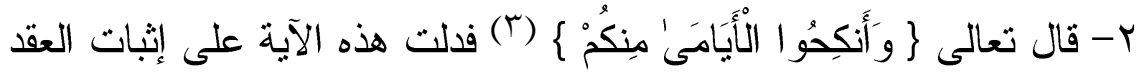

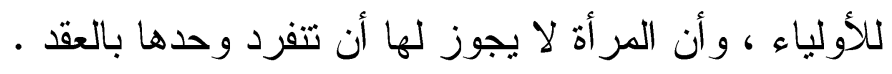

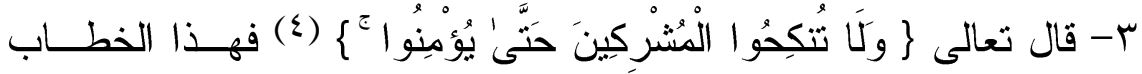

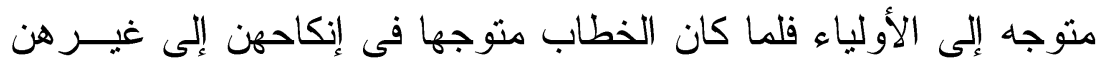

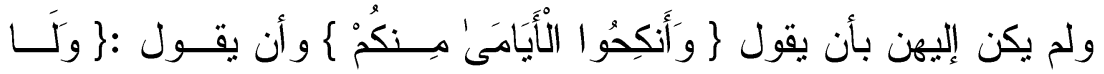

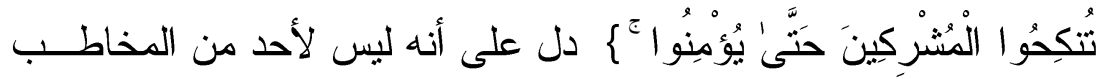
فيهن أن يزوج نفسه (0)

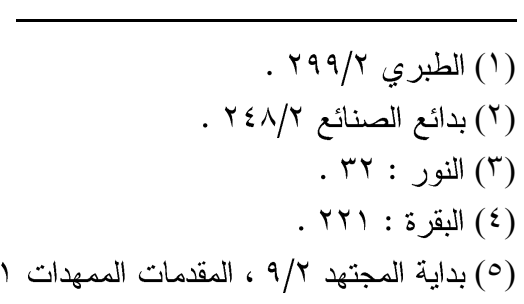




\section{ب- أدلتهم من السنة :}

أما الأحاديث التي تؤيد مذهبهم فهي كثثرة نذكر منها :

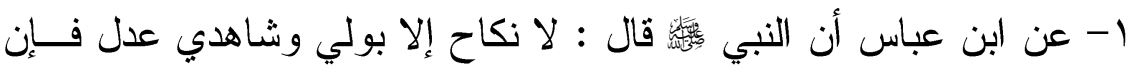

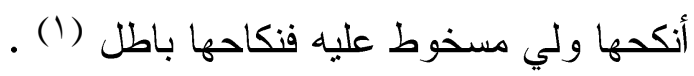

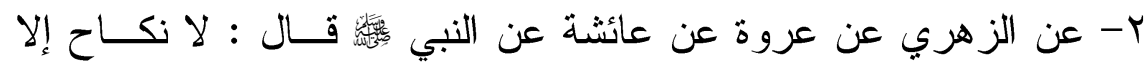
بولي (r) (ب) ب- عن عمران بن حصين قال : قال رســـول الله وشاهدي عدل • وروي عن أبي بريدة مثل ذلك (r) .

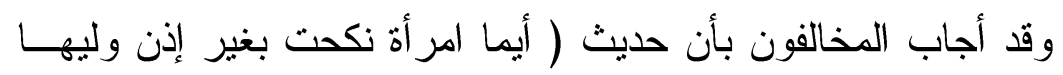

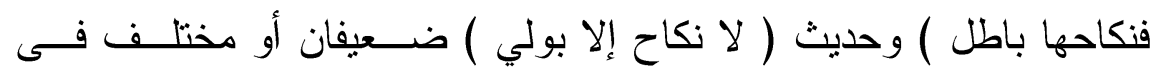

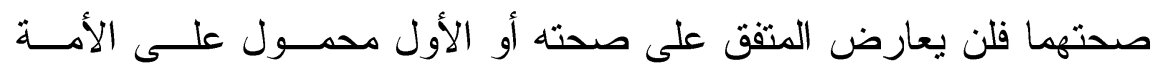

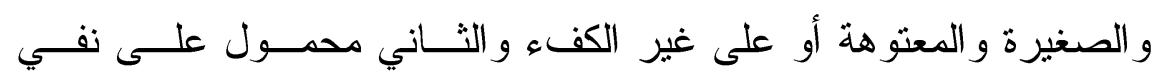

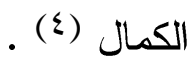

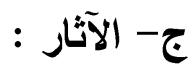
فقد روي عن جماعة من الصحابة آثار كثيرة تدل على تحريم النكاح بغير ولي منها : - n

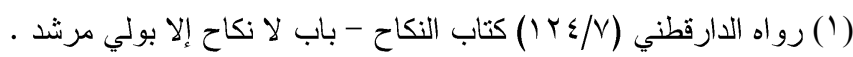

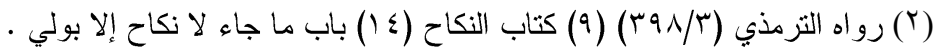

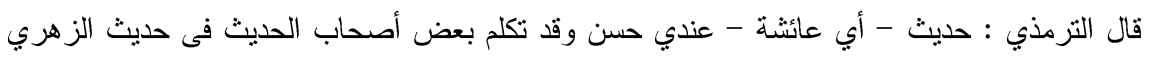

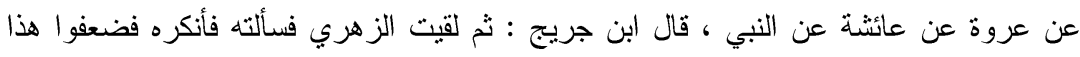

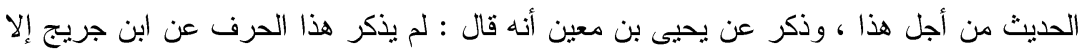

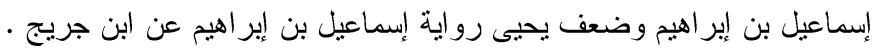

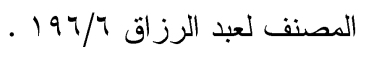

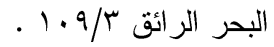


1- عن الثعبي قال : إن عمر وعلياً وابن مسعود وشــريحاً لا يجيـزون

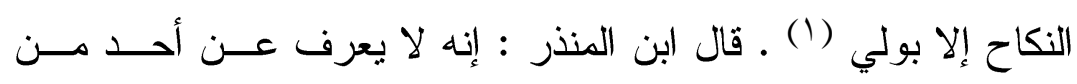

الصحابة خالف ذلك (r)

r- عن ابن عباس قال : لا نكاح إلا بولي أو سلطان فإن أنكحهــا سـفيهاً

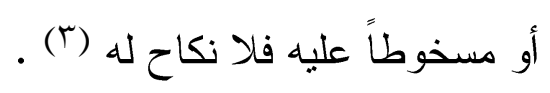

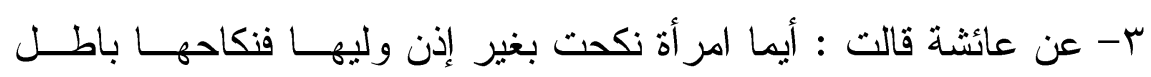

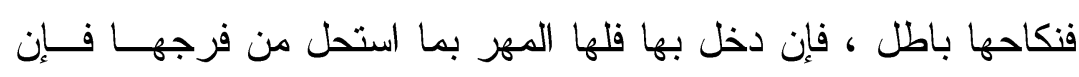

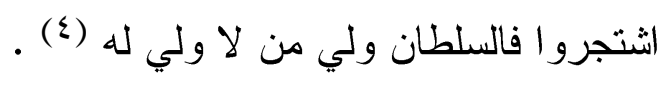

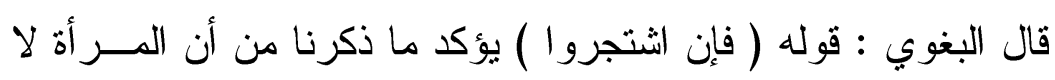

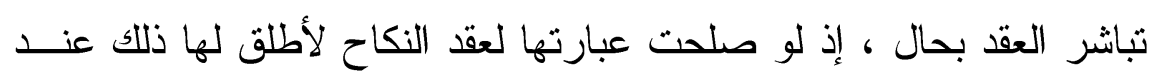

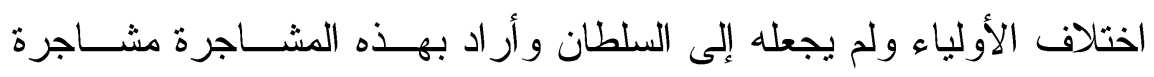

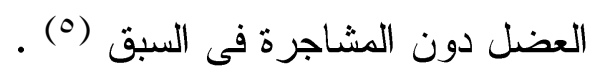

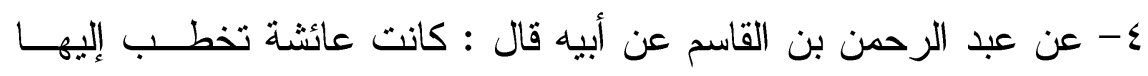

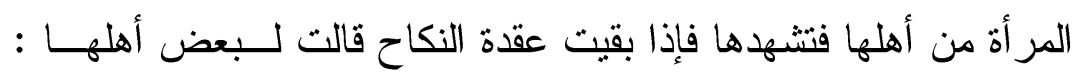

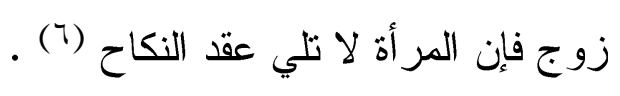

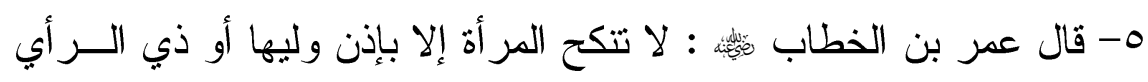

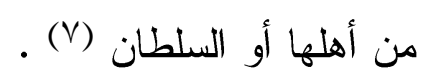

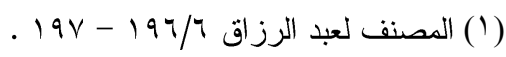

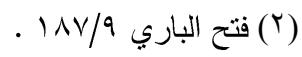

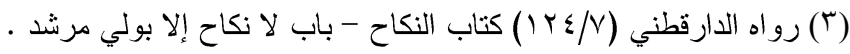

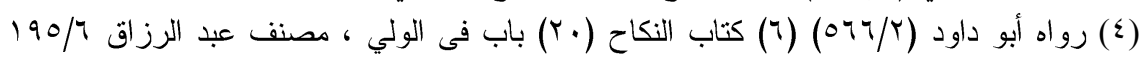

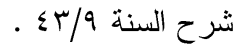

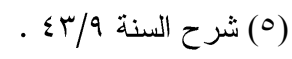

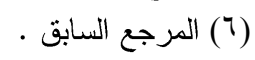

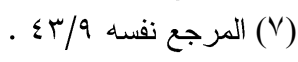




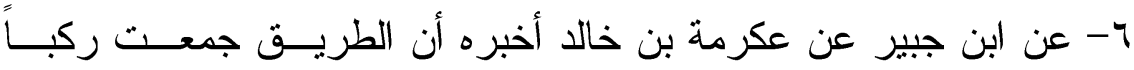
فجعلت امر أة ثيباً أمرها إلى رجل من بن القوم غير ولي فأنكحها رجـلا

فبلغ ذلك عمر بن الخطاب فجلد الناكح و المنكح ورد نكاحهما (1) .

\section{ثنانيا الأدلة من المعقول :}

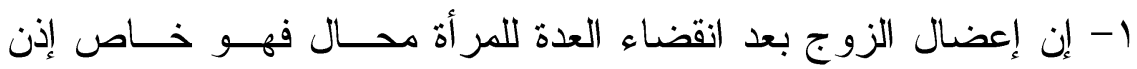

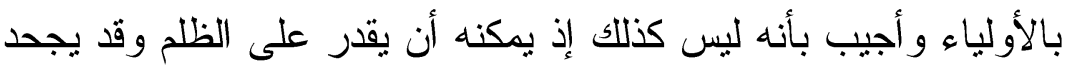

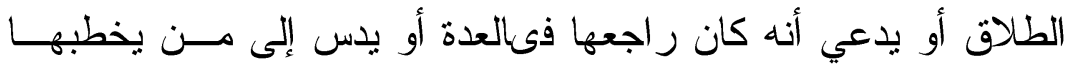

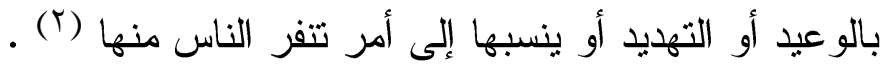

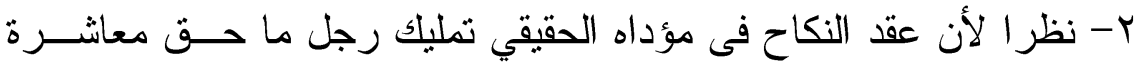

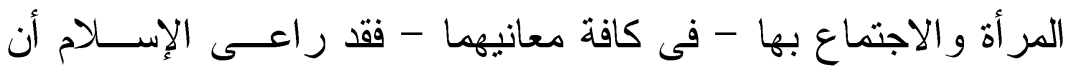

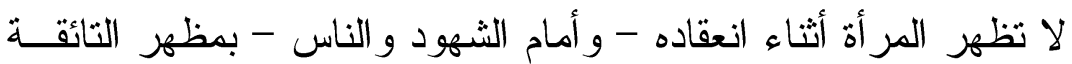

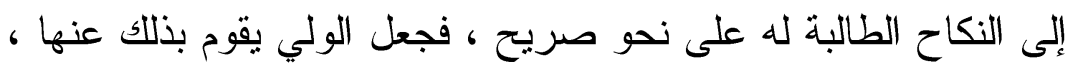

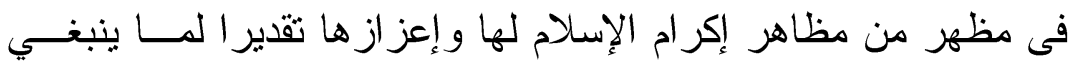
نحو ها من و اجب حمايتها من أي موقف يمس حياءها و عزتها فإظهار

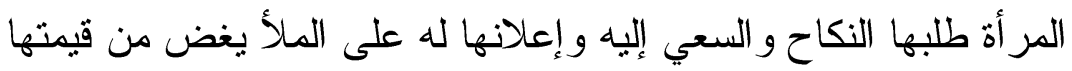

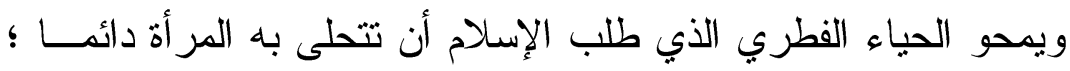

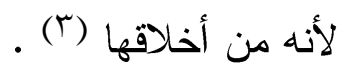

ب- إن التكوين النفسي للمر أة يجعلها تتجه فى الغالب إلى تحكيم عاطفتها مما

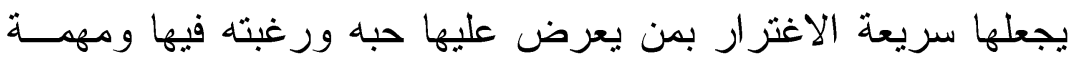

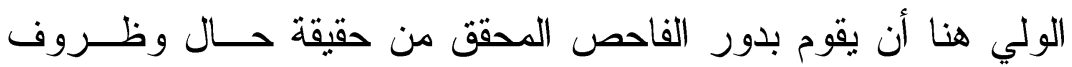

$$
\text { (1) (199/7 المصنف لعبد الرزاق . (1) }
$$


الرجل فحين اشترط الإسلام أن يباشر الولي عقد النكاح فمعنى هذا أنه

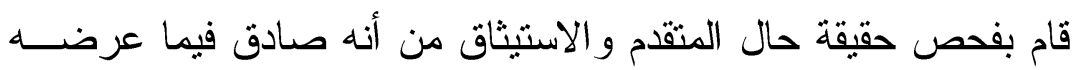

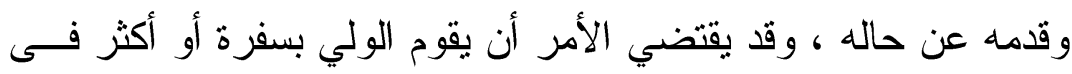

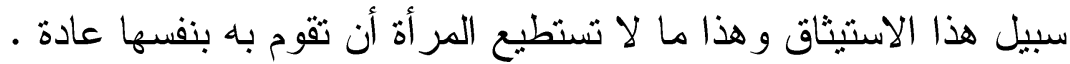

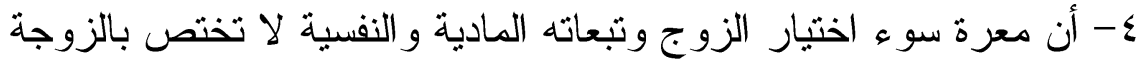

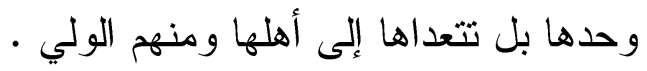

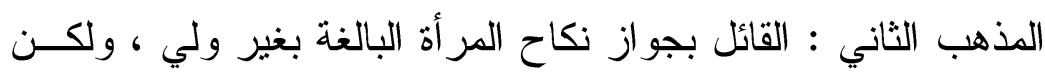

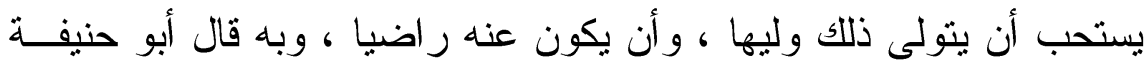

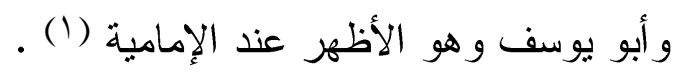

وقد استدلوا على ذلك بعدة أدلة من المنقول ومن المعقول (r) :

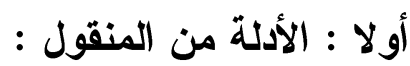
أ- الكتاب : (1)

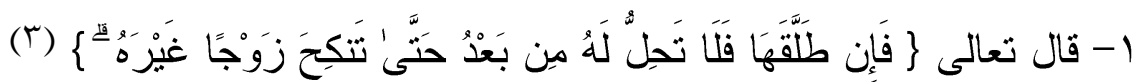

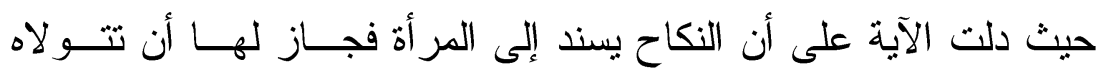
بنفسها.

و أجيب عن ذلك بأن الآية على معنى : تتكح بإذن وليها فلـيس الـــص

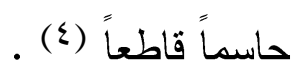

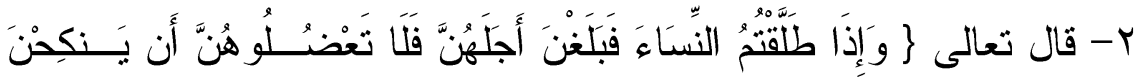

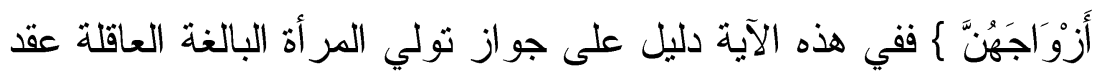

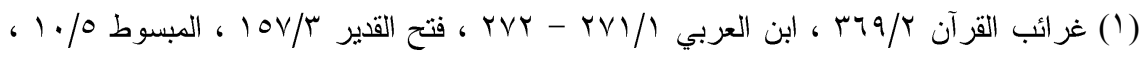

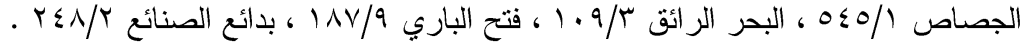

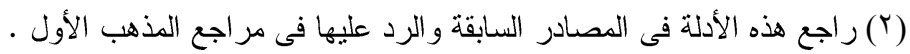

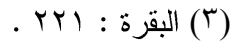

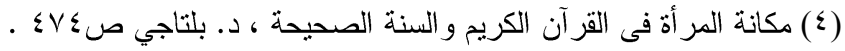




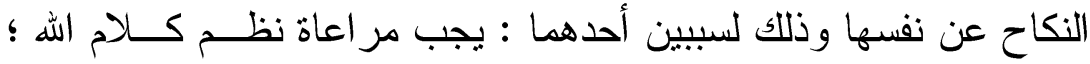

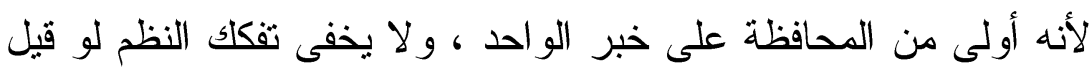

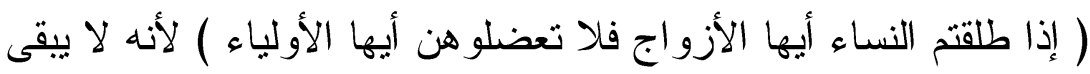
بين الشرط و الجز اء مناسبة . الداء التهاء

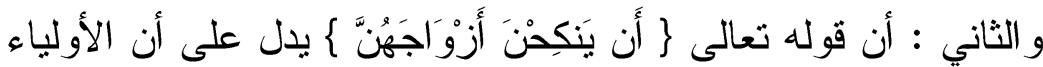

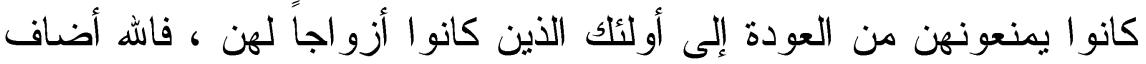

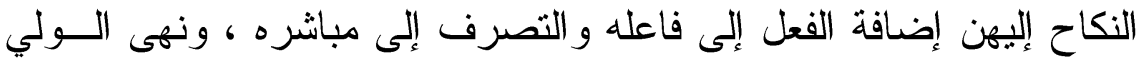

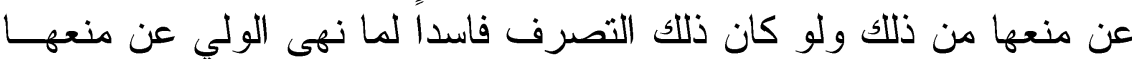
منه

و أجيب عليهم بأن قولهم يجب مر اعاة نظم الآية فهو ليس كما ذكروه، فللمر أة حق طلب النكاح ، وللولي حق المباشرة للعقــد ، فــإذا أرادت مــن فئن يرضى حاله و أبى الولي من العقد فقد منعها مر ادها وهذا بين .

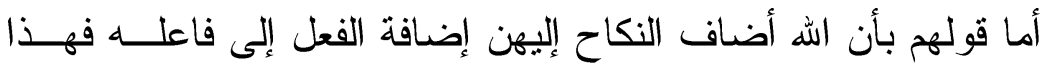

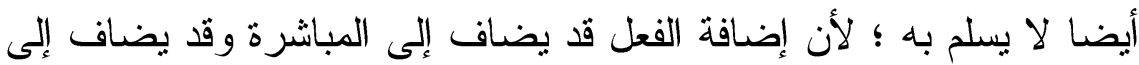

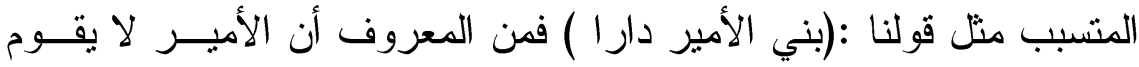

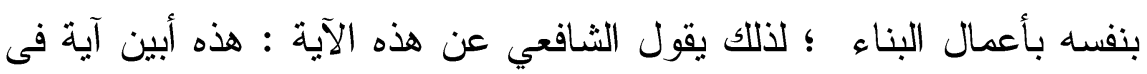

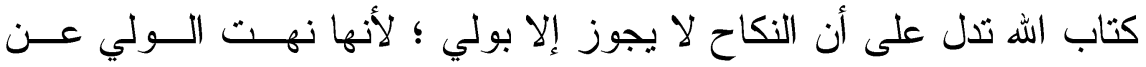

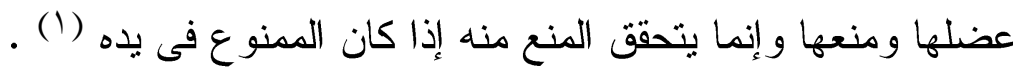

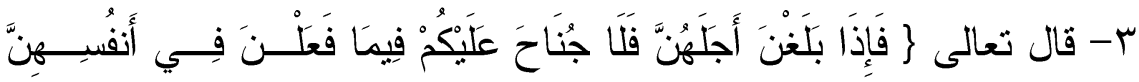

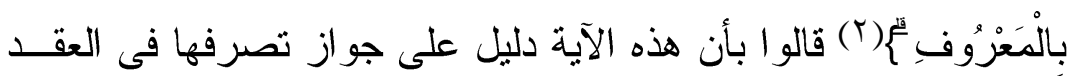
على نفسها 
وقد أجاب ابن العربي عن هذا الاليل فقال : هذا خطاب للأولياء وبيان

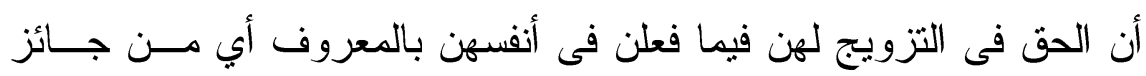

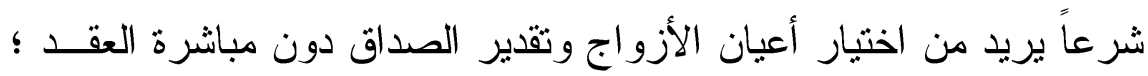

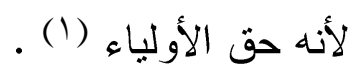

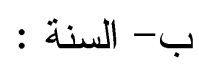

أما دليلهم من السنة فقد استـلو ا بحديث رسول الله

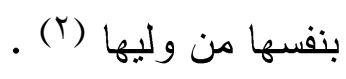

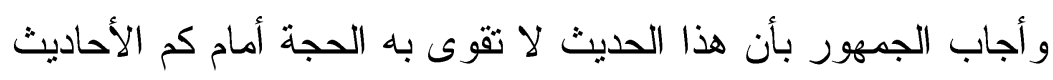

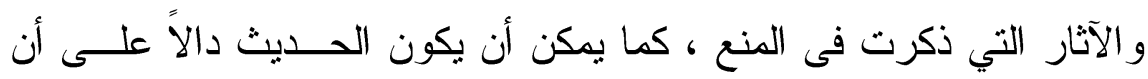

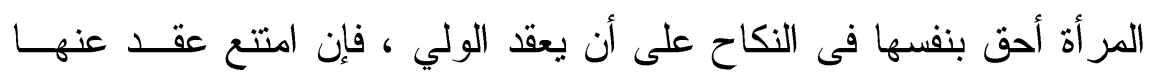

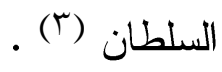
ثانيا : أدلتهم من المعقول : العنان

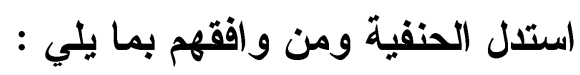

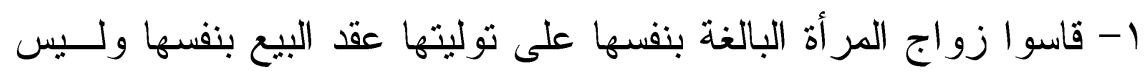

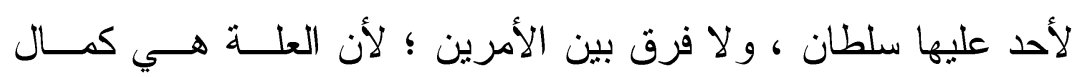

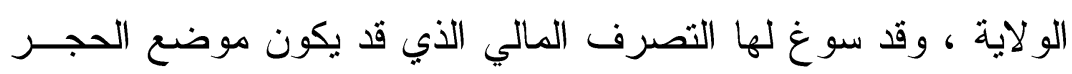

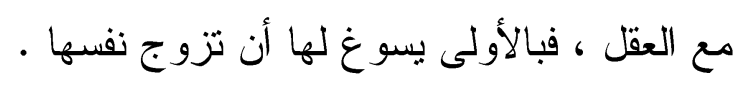

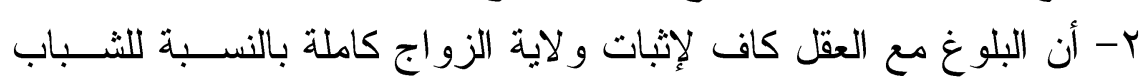

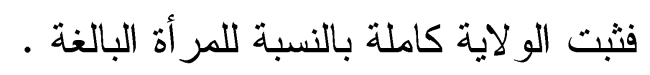

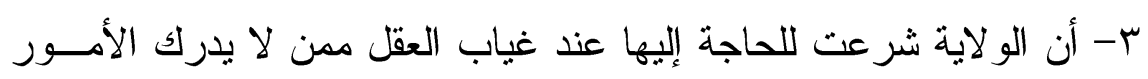

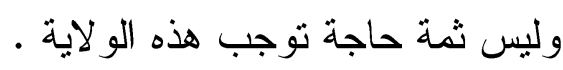

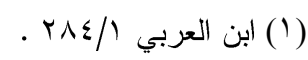

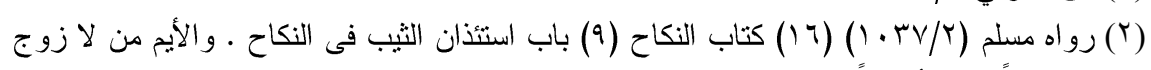

$$
\begin{aligned}
& \text { الها بكرأ كانت أو ثيباً. }
\end{aligned}
$$

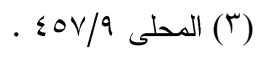


و أجيب عليهم بأن قولهم إن المر أة أملك لنفسها قياساً على البيع ، وهذا

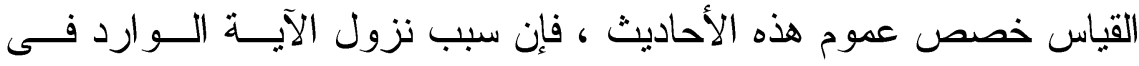

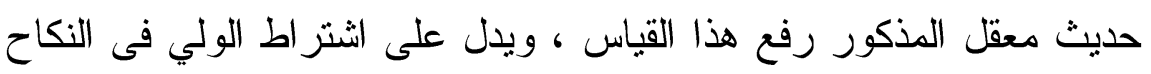

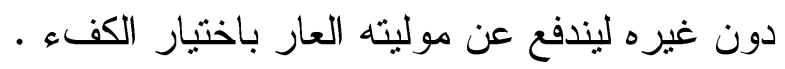

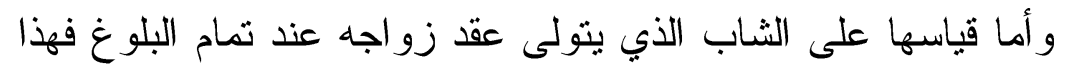

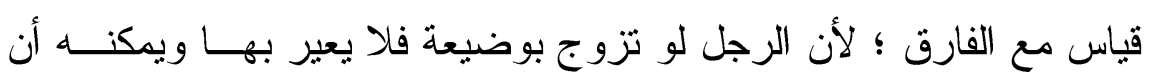

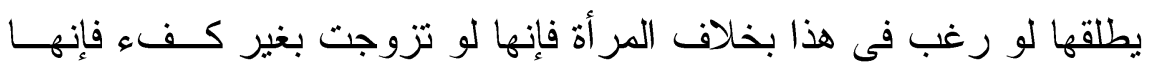
تعير هي وأهلها.

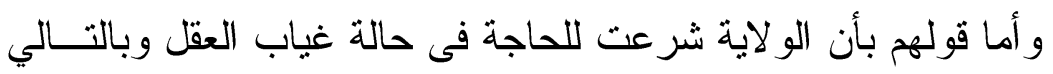

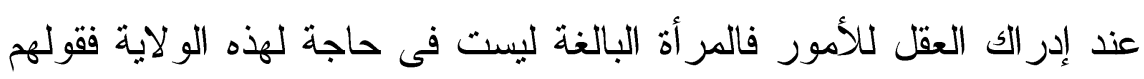

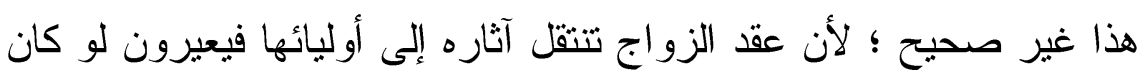

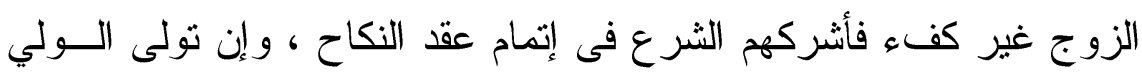
لعقد الزو اج بمو افقة المر أة البالغة فيه حفظ لكئ لكر امتها التي كرمها الإنسام بها.

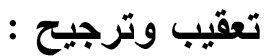

بعد عرض أدلة كل فريق ومناقثة أدلته يتبين رجحان قول الجمهور

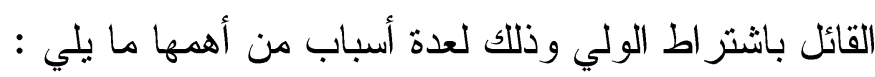

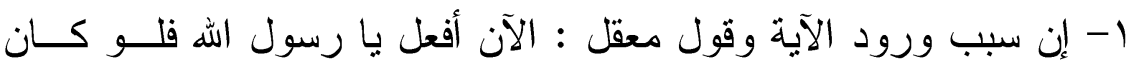

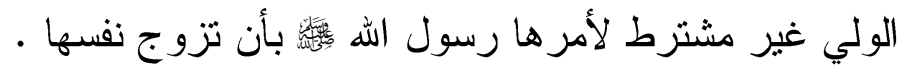

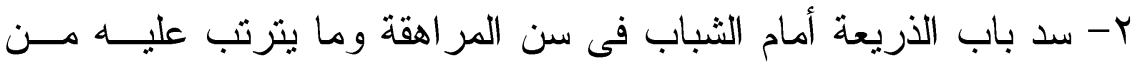

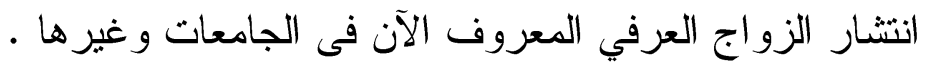

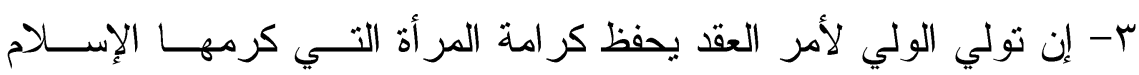

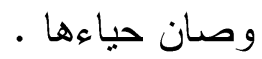

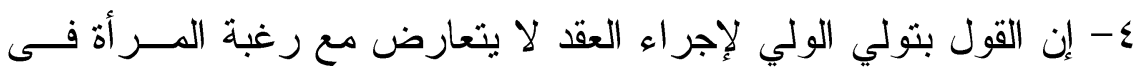

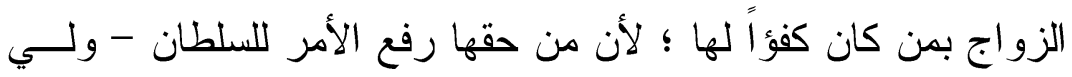

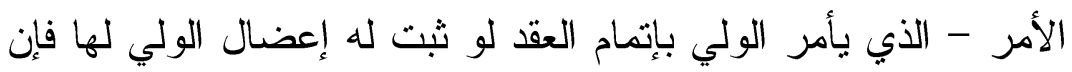

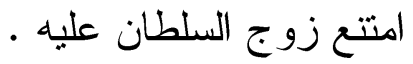




\section{بقي أن أثنير إلى شيئين :}

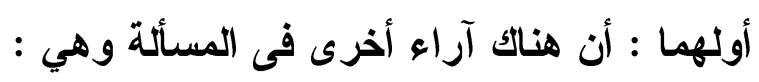

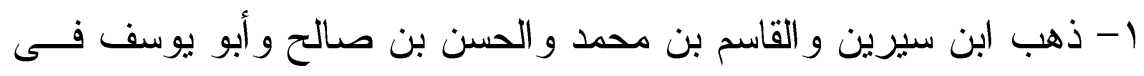

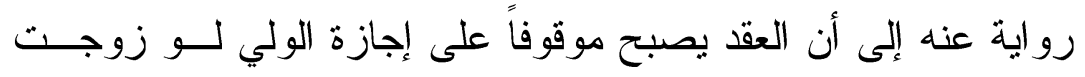

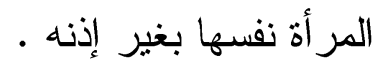

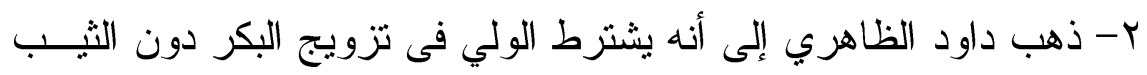

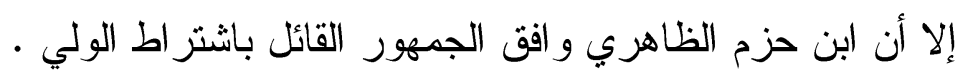

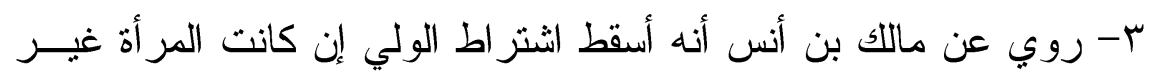

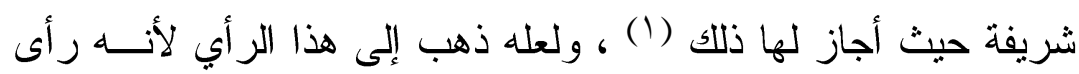

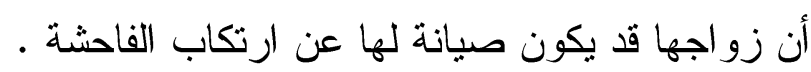

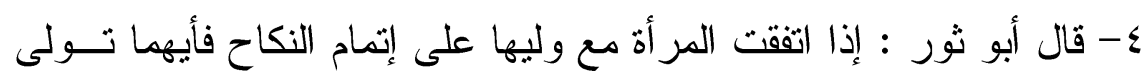

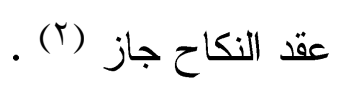

وقد أيد د. زكي الدين شعبان رأي أبي ثور حيث قال : ومن يتأمل فى الى الثي

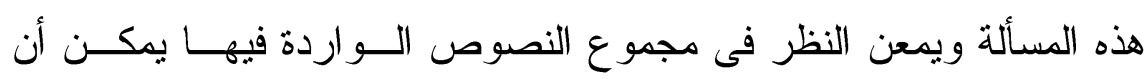

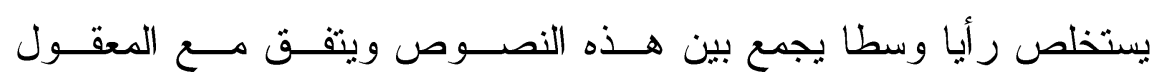

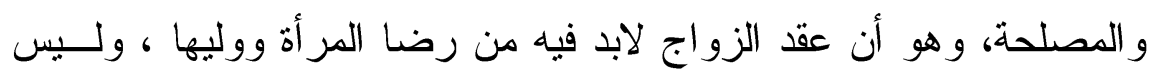

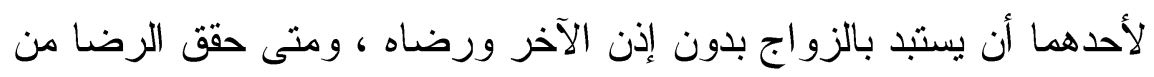

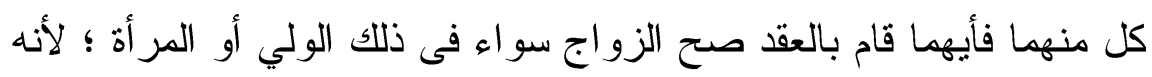

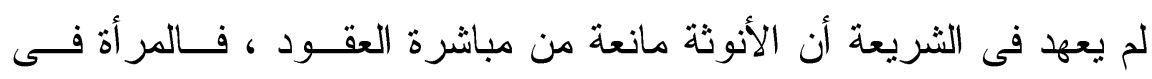

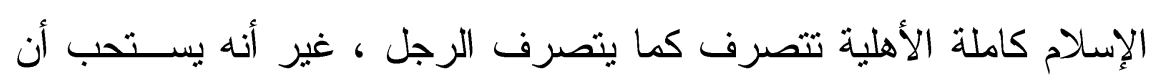




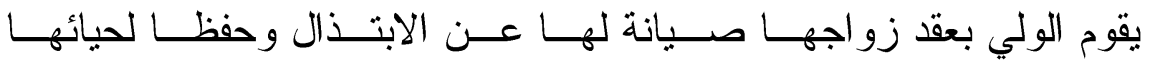
وحشمنها (1)

ثانيهما : أن أبا حنيفة عندما أجاز إسقاط الولي للمر أة البالغة العاقلـــة

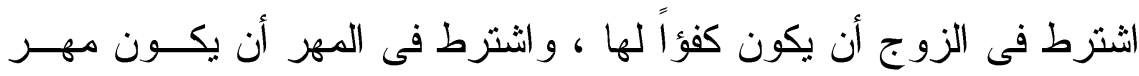

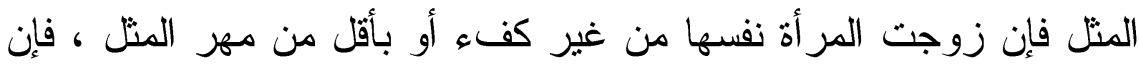

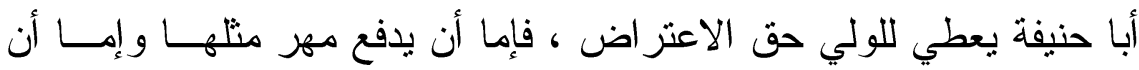

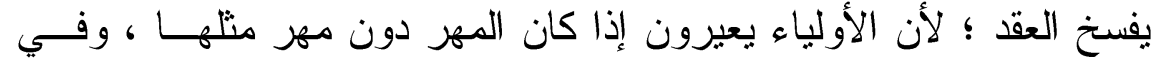

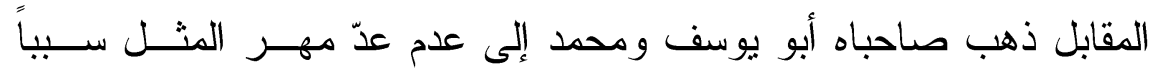

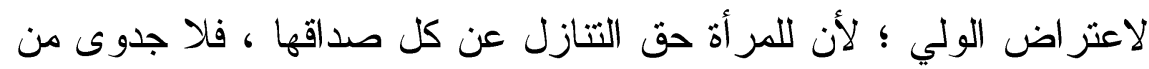

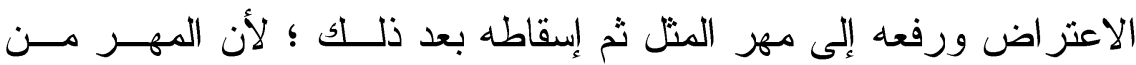

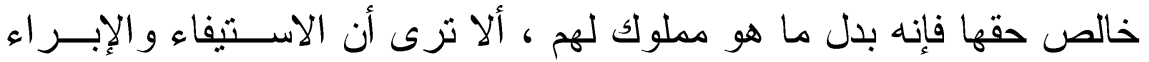

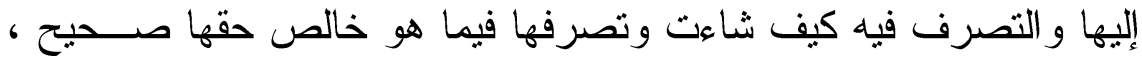

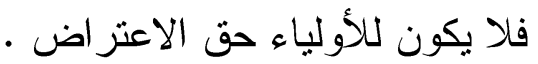

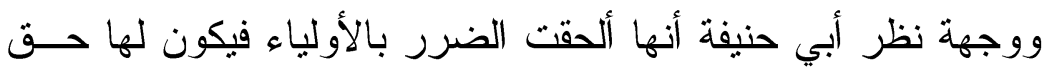

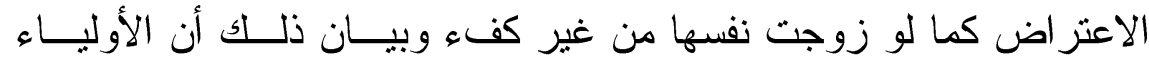
يتفاخرون بكمال مهر ها ويعيرون بنقصان مهر ها (r) . 


\section{الخاتمتة}

أود أن أذكر أهم النتائج الني توصلت إليها ومنها : 1-أكدت الدراسة أن هناك فرق بين الاختلاف وانج الخلاف و وأن الذي وقع بين

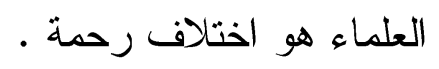

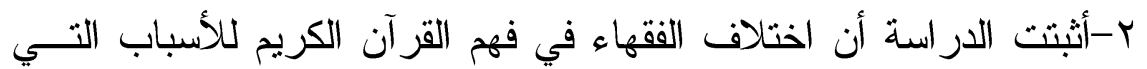
ذكرناها أكبر الأثر في اختلافهم في بعض قضايا المر أة .

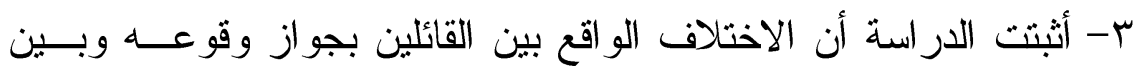
القائلين بعدم جو از وقو عه في فروع الثريعة خلافا شكليا .

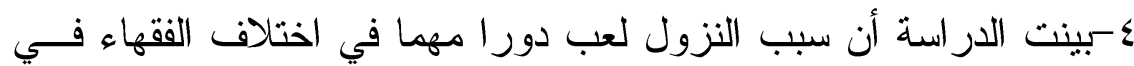
أحكام المر أة كما في مسألة إتيان النساء في الدبر ومسألة السبي يهــدم - مالنكاح

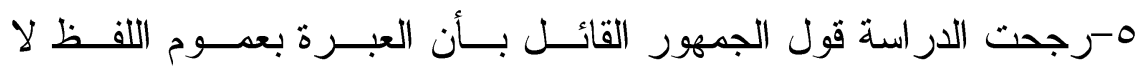

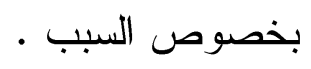

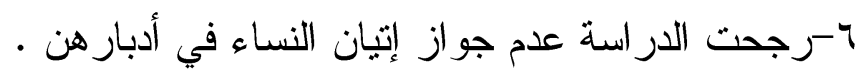

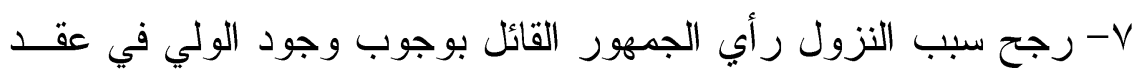

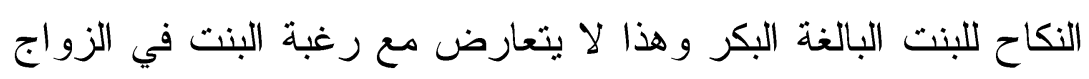
بمن كان كفو الها لأن من حقها رفع الأمر إلى ولي أمر المسلمين الذي لئي

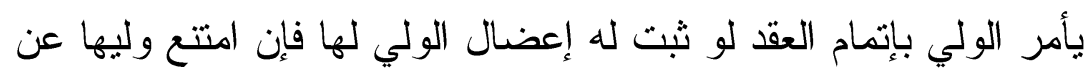
تزويجها زوجها السلطان. ^- رجحت الدراسة أن المعنى في قوله [ إلا ما ملكت أيمانكم ] يعني بـــه

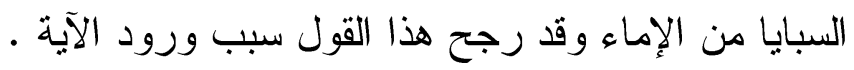




\section{المصادر والمراجع}

أولا : التفسير وعلوم القرآن :

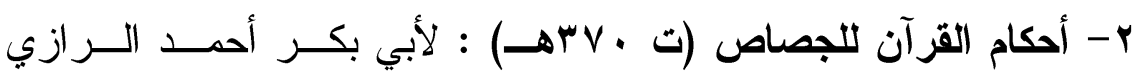

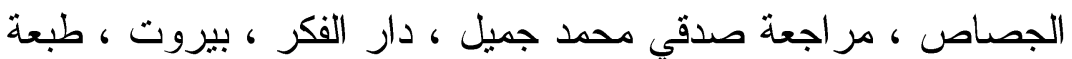
- مो

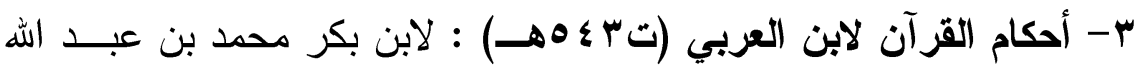

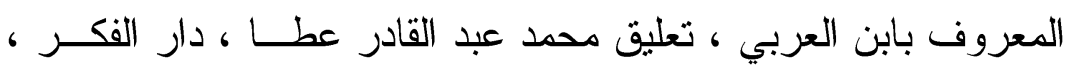

$$
\text { بيروت }
$$

ع - جامع البيان فى تفسير القرآن : لأبي جعفر محمد بن جرير الطبري ، لقدي

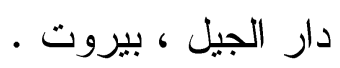

ه- الجامع لأحكام القرآن للقرطبي (ت الت آهــ) : لأبي عبد الله محمد بن

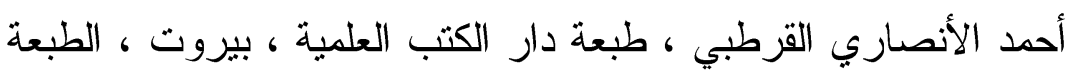

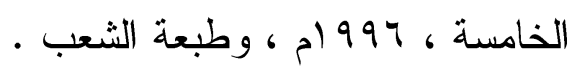

צ- غرائب القرآن : لنظام الدين القمي النيسابوري ، تحقيق إبراهيم عطوة عوض البابي الحلبي ، طبعة بهامش الطبري ، دار الجيل .

$$
\text { ثانيا : كتب الحديث : الجيث }
$$

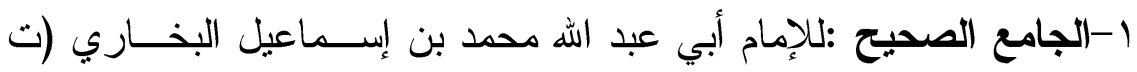

$$
\text { (ד) }
$$

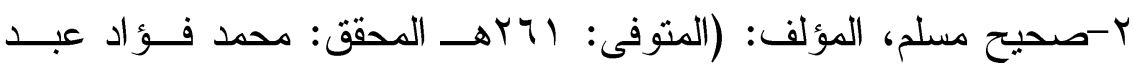

$$
\text { الباقي - الناشر : دار إحياء التزاث العربي لئي }
$$

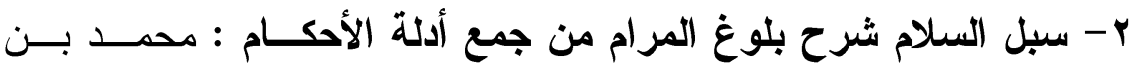

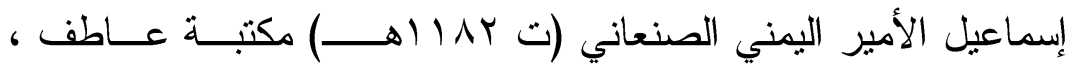
القاهرة .

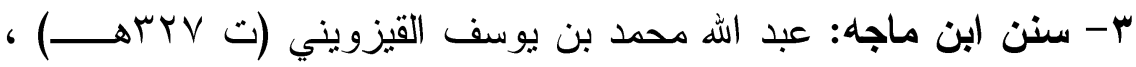

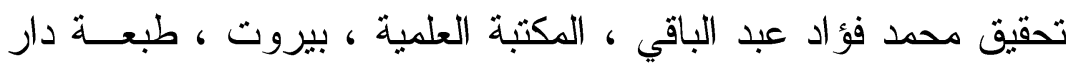

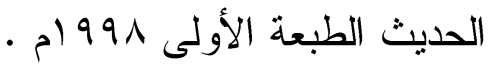


ع- سنن أبي داود : لأبي داود سليمان بن الأشعث السجستاني ، دار الريان

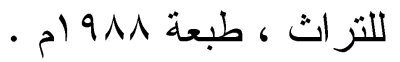

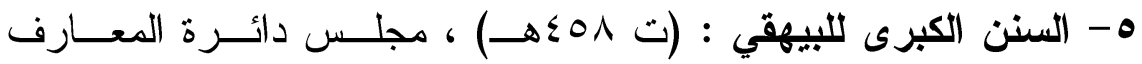

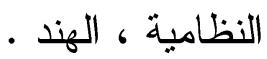

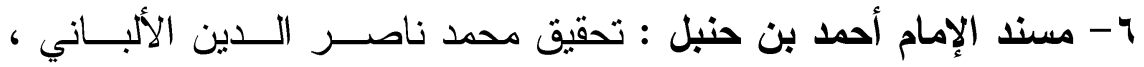

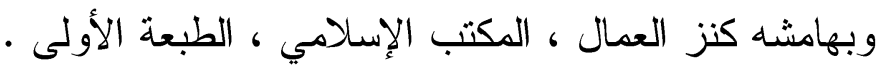

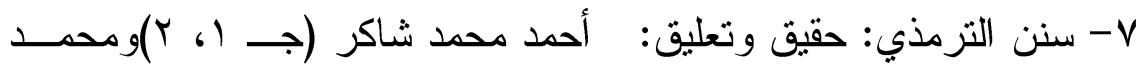

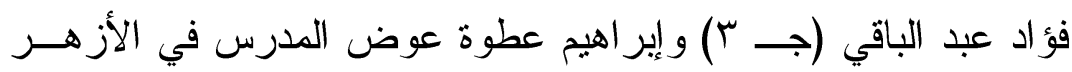

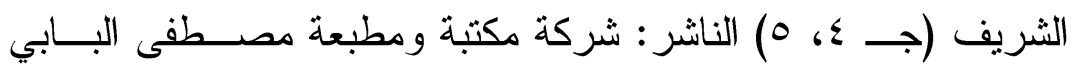

ثالثا: كتب أصول الفقه

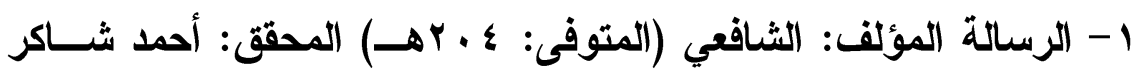

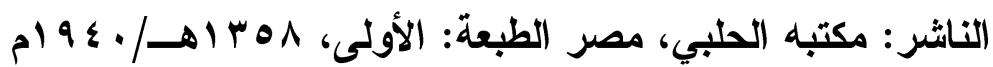

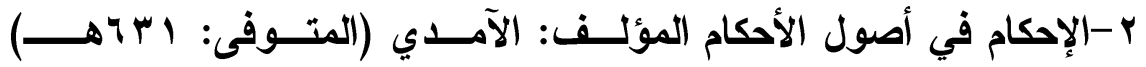

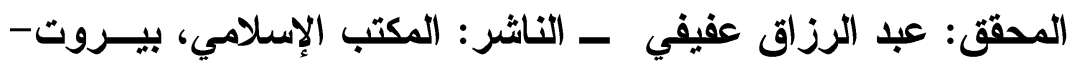

$$
\begin{aligned}
& \text { دمشق - لبنان. } \\
& \text { رابعا : كتب الفقه : } \\
& \text { أ- المذهب الحنفي : }
\end{aligned}
$$

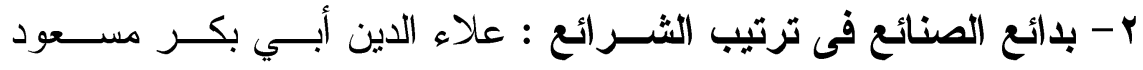

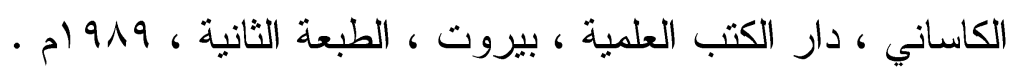

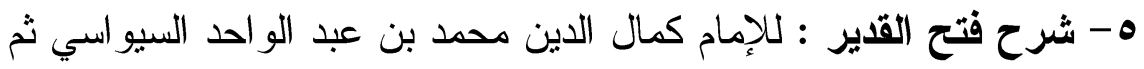

السكندري المعروف بابن الهمام الحنفي ، مطبعة مصطفى البابي الحلبي

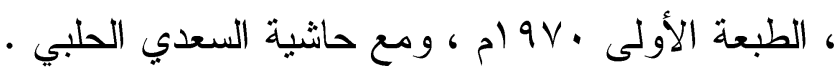

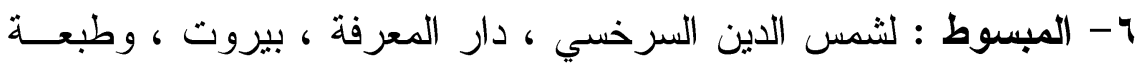

أخرى لدار الفكر ، بيروت ، و ولا فرق بين الطبعتين .

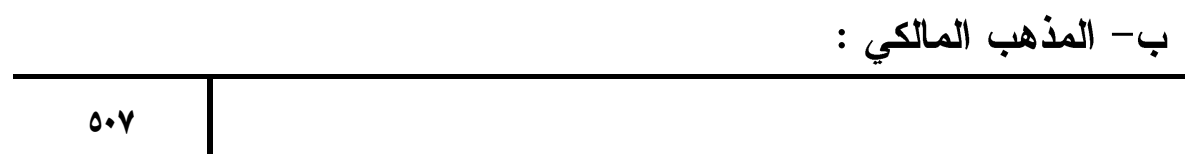


ا-بداية المجتهد ونهاية المقتصد : للقاضي أبو الوليد محمد بن أحمد بــن

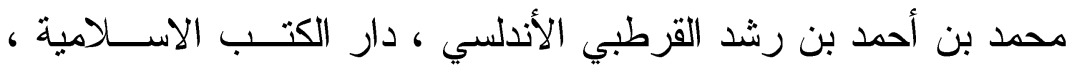
الطبعة الثانية سم/9 1.

r-المقدمات الممهدات المؤلف: أبو الوليد محمد بن أحمد بن رشد القرطبي

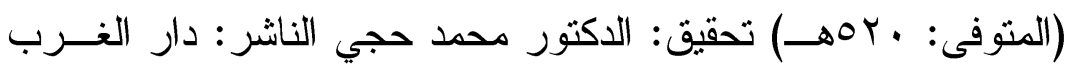

$$
\text { الإسلامي، بيروت - لبنان }
$$

ب-الكافي فى فقه أهل المدينة المالكي : محمد بن عبد البر النمري القرطبي

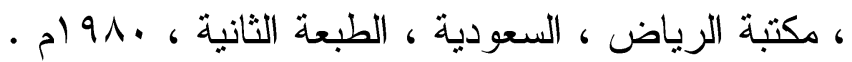

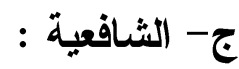

1- إعانة الطالبين : للعلامة السيد أبو بكر المشهور بالسيد البكري ، إحياء

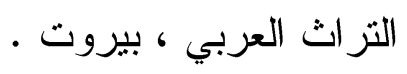

r-الحاوي الكبير : لأبي الحسن علي بن محمد بن حبيب المساوردي ، دار

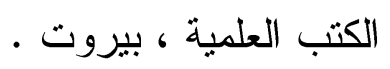

ب-زاد المحتاج بشرح المنهاج : حسن الكوهجي ، تحقيق عبد اله إبــر اهيم

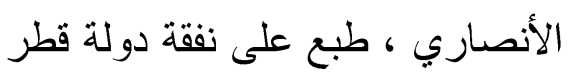

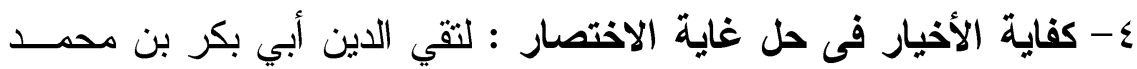

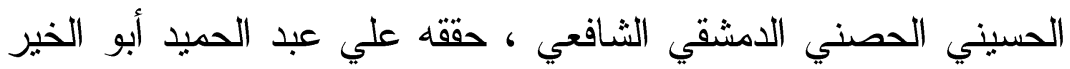

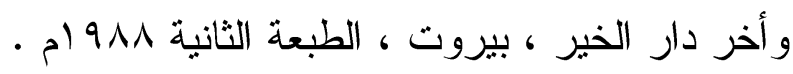
ه-المنهاج : لأبي زكريا يحيى بن شرف النووي ، مصطفى البابي الحلبي

$$
\begin{aligned}
& \text {. م) } \\
& \text { د- المذهب الحنبلي : }
\end{aligned}
$$

1- الإنصاف فى معرفة الراجح من الخلاف على مذهب الإمام أحمـــ بــن

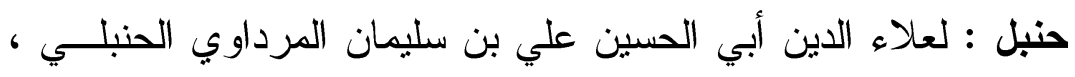

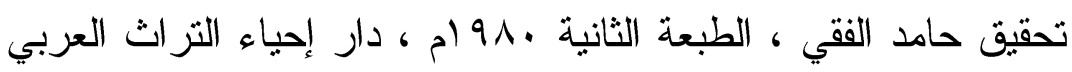

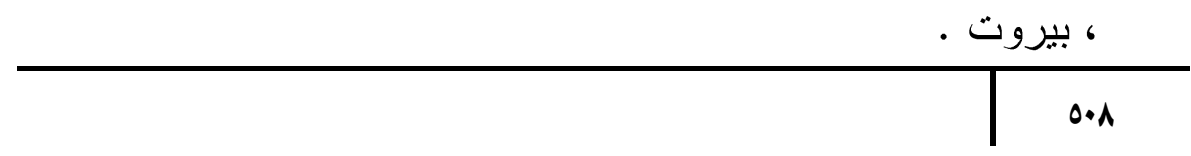


ץ- حاثية النجدي على الروض المربع : لعبد الرحمن بن محمد بن قاسـم

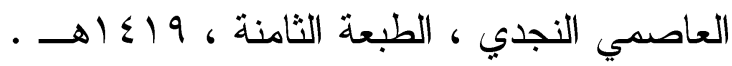

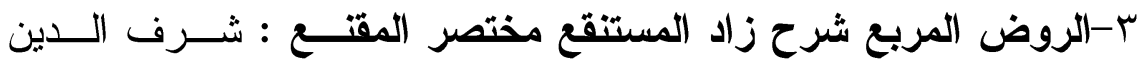

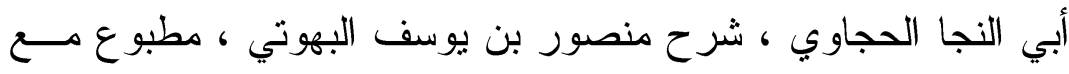

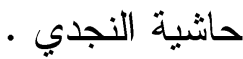
ع-شرح منتهى الإرادات المسمى دقائق أولي النهـى لثــرح المنتهـى :

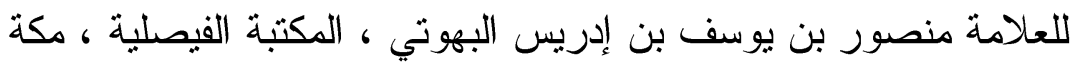
المكرمة . ه-المبدع فى شرح المقتع : لابن مفلح ، المكتب الإسلامي ، بيروت .

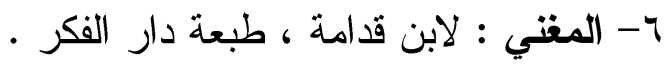

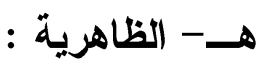
المحلى : لابن حزم : أبي محمد علي بن أحمد بن سعيد بــن حـزم ، دار

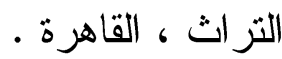

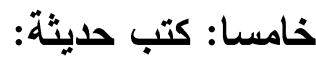
1-أسباب اختلاف الفقهاء المؤلف: عبــد الله بـن عبــــ المحسـن بـن

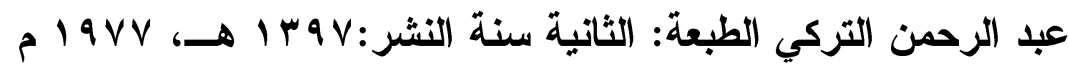


مجلة كلية الدراسات الإسلامية والعربية للبنات بدمنهور العدد الخامس الجزء الرابع عشر •r.rم 